\title{
Antibacterial Titanium Implants Biofunctionalized by Plasma Electrolytic Oxidation with Silver, Zinc, and Copper: A Systematic Review
}

\author{
Ingmar A. J. van Hengel *(D), Melissa W. A. M. Tierolf, Lidy E. Fratila-Apachitei (D), Iulian Apachitei and \\ Amir A. Zadpoor
}

check for updates

Citation: van Hengel, I.A.J.; Tierolf, M.W.A.M.; Fratila-Apachitei, L.E.; Apachitei, I.; Zadpoor, A.A. Antibacterial Titanium Implants Biofunctionalized by Plasma Electrolytic Oxidation with Silver, Zinc, and Copper: A Systematic Review. Int. J. Mol. Sci. 2021, 22, 3800.

https://doi.org/10.3390/ijms22073800

Academic Editor: Sotiris Hadjikakou

Received: 16 February 2021

Accepted: 5 April 2021

Published: 6 April 2021

Publisher's Note: MDPI stays neutral with regard to jurisdictional claims in published maps and institutional affiliations.

Copyright: (c) 2021 by the authors. Licensee MDPI, Basel, Switzerland. This article is an open access article distributed under the terms and conditions of the Creative Commons Attribution (CC BY) license (https:// creativecommons.org/licenses/by/ $4.0 /)$.
Department of Biomechanical Engineering, Faculty of Mechanical, Maritime, and Materials Engineering, Delft University of Technology, 2628 CD Delft, The Netherlands; melissa_tierolf@hotmail.com (M.W.A.M.T.); e.l.fratila-apachitei@tudelft.nl (L.E.F.-A.); i.apachitei@tudelft.nl (I.A.); a.a.zadpoor@tudelft.nl (A.A.Z.)

* Correspondence: i.a.j.vanhengel@tudelft.nl

Keywords: plasma electrolytic oxidation; additive manufacturing; titanium bone implants; antibacterial biomaterials; surface biofunctionalization; implant-associated infection

\section{Introduction}

Implant-associated infections (IAI) are a devastating complication for patients receiving bone implants in total joint arthroplasty, trauma surgeries, and malignant bone tumor resections [1-3]. These infections form a tremendous burden for both patients and society. As the number of implantations continues to grow annually [4-6], the need for a cure increases. Given that the treatment of such infections is highly costly from both financial and societal points of view, the focus has shifted towards the prevention of IAI through the development of implants with intrinsic antibacterial activity.

Antibiotics form the primary source of antibacterial agents used to treat bacterial infections. However, a vast number of IAI is caused by Staphylococci and multiple strains have developed high levels of antibiotic resistance $[7,8]$, raising concerns for the future 
treatments of IAI. Infection by methicillin-resistant Staphylococcus aureus (MRSA) highly complicates the treatment of IAI and adversely affects the treatment outcomes $[9,10]$. Other antibacterial agents are, therefore, being investigated. Metallic elements, such as $\mathrm{Ag}, \mathrm{Cu}$, and $\mathrm{Zn}$ have shown strong antibacterial behavior against a wide microbial spectrum, including resistant bacterial strains [11-14].

$\mathrm{Ag}$ has excellent antibacterial properties, but may also induce cytotoxicity $[15,16]$. Cu and $\mathrm{Zn}$, on the other hand, exhibit lower levels of antibacterial behavior, but are essential trace elements. Furthermore, they have been found to enhance the cytocompatibility of implant surfaces $[17,18]$. Therefore, combining these elements may result in the right balance between antibacterial behavior, chemical biocompatibility, and osteogenic response $[19,20]$.

The local administration of antibacterial agents at the implant site was shown to greatly complement the systemic administration of antibiotics [21,22]. The side effects of such agents can also be prevented as the required antibacterial dose is generally lower [23]. To deliver antibacterial agents locally, the surface of the implants can be biofunctionalized through surface treatment techniques. Antibacterial agents can be attached to implants either as a coating layer, embedded directly onto the implant surface, or incorporated as part of a converted surface layer [24].

Antibacterial agents can be deposited onto the implant surface by means of polymeric, ceramic or metallic coatings. To produce these coatings, usually low temperatures are used and therefore little interaction occurs with the implant substrate. Coatings have a tendency to be thin and fragile, thereby limiting the availability of the antibacterial agent and hampering their use during surgical implantation. To enhance the diffusion, the antibacterial agent can be incorporated in a biodegradable polymer coating. In this way implants were manufactured that contain Ag [25,26], Cu [27], and Zn [28]. Polymeric coatings can be attached onto an implant by dipping and drying, sol-gel technology, spray drying, layer-by-layer manufacturing, and self-assembly monolayers. Downsides are the limited mechanical and chemical stability, local inflammatory response due to degradation products, and uncontrolled release kinetics.

Another strategy is direct embedding of the antibacterial agent into the implant surface. In this way, no new material is added on top of the substrate, but the composition of the outermost layer of the implant substrate is altered. Examples of such methods are ion implantation, plasma immersion ion implantation [29], and in situ reduction [30]. Advantages are that the implant surface morphology remains intact, and the corrosive and biocompatible properties of the substrate material retained. However, this strategy is difficult to perform on complex geometries and does not allow for optimization of the surface morphology.

A third approach to incorporate $\mathrm{Ag}, \mathrm{Cu}$, and $\mathrm{Zn}$ in the implant surface is through generation of a converted surface layer. One such technique is plasma electrolytic oxidation (PEO), which was investigated to biofunctionalize the surface of highly porous implants made of specific metallic biomaterials [31]. During PEO, the native titanium oxide layer is transformed into a crystalline and microporous surface in a swift and single-step process.

Through the addition of antibacterial elements into the PEO electrolyte, these elements become part of the converted surface layer and result in a surface exhibiting antibacterial behavior [32,33]. Due to the tight embedding of the antibacterial agents into the surface, the release of these ions can be controlled and the undesired circulation of agents can be prevented, thereby avoiding nanotoxic effects [34]. PEO was applied to generate titanium implants with antibacterial properties using $\mathrm{Ag}$, $\mathrm{Cu}$, and $\mathrm{Zn}$ [35-37]. In addition to the antibacterial behavior, PEO biofunctionalized surfaces were shown to enhance osseointegration and stimulate bony ingrowth in vivo [38,39].

Bone implants are increasingly produced through additive manufacturing (AM), as this allows free-form fabrication and customized treatment for patients. AM allows for the fabrication of highly porous implants with vast internal surface areas, which may make the implants more prone to infection, while at the same time providing a challenging surface to modify through surface biofunctionalization techniques. PEO is capable of biofunction- 
alizing the surface of complex geometries. In addition, the parameters of the PEO process can be controlled, which allows to tailor the chemistry of the surface layer [40,41]. Furthermore, the synthesized surface layer adheres strongly to the implant substrate. Moreover, the method is easily scalable towards clinically sized implants. Limitations of PEO are that the surface morphology and chemistry of the surface are modified simultaneously and this makes the individual tuning of these properties difficult. Furthermore, the exact mechanism of plasma discharging is still unknown, and thereby the fine-tuning of the PEO processing parameters difficult to predict [42].

In order to develop clinically relevant antibacterial implants, it is important to assess the progress made in this area and compare the outcomes of different studies. As most implants available for current clinical use are made of titanium, we performed a systematic review on titanium implants biofunctionalized by $\mathrm{PEO}$ using $\mathrm{Ag}$, $\mathrm{Cu}$, and $\mathrm{Zn}$. In order to illustrate the progress made in this area, we screened the studies published between 2009 and December 2020. This area of research involved several scientific disciplines, including engineering, material sciences, microbiology, and orthopedics. We, therefore, analyzed a broad spectrum of aspects including the implant substrate, PEO parameters, surface characteristics, antibacterial assays, and cytocompatibility testing.

\section{Methods}

\subsection{Literature Search}

A comprehensive electronic search was performed using Scopus and Google Scholar search engines up until December 2020. In addition, a global screening was performed using PubMed. The article search was conducted using different combinations of the following keywords: plasma electrolytic oxidation, micro-arc oxidation, antibacterial activity, $\mathrm{Ag}, \mathrm{Cu}$, and $\mathrm{Zn}$. To ensure that relevant publications were not excluded, combinations of subject headings, text-word terms, and the Boolean operators AND and OR were used. The searches were limited to those studies published in English between 2009 and 2020. The reference lists of the included eligible studies were scanned to ensure no eligible studies were omitted. The last search date was 24 December, 2020. This systematic review was written according to the PRISMA (Preferred Reporting Items for Systematic Review and Meta-Analyses) statement [43].

\subsection{Inclusion and Exclusion Criteria}

The inclusion criteria were-(1) the surface modification technique: plasma electrolytic oxidation (PEO), micro-arc oxidation (MAO), or anodic spark deposition (ASD); (2) implant substrate: titanium and its alloys; (3) antibacterial agents: Ag, Cu and Zn; (4) metallic-based antibacterial agents should have been incorporated in PEO-modified Ti-based surfaces; and (5) assessment of the antibacterial behavior should have been performed. A study was excluded if it did not report any outcome variable. Furthermore, studies were not eligible for inclusion when-(1) articles were not published in English; (2) no surface modification technique was utilized; (3) PEO was performed in combination with other surface modification techniques or treatments; (4) no antibacterial testing was performed; and (5) study was of one of the following document types: reviews, patents, conference abstracts/papers, and case reports.

\subsection{Study Selection}

The titles and abstracts were screened to assess the suitability of the search results. Subsequently, the full-text of the studies selected in the first stage of screening were analyzed to assess whether or not they satisfied the inclusion criteria.

\subsection{Risk of Bias}

The methodological details of the included studies were analyzed to minimize the risks of biases in the individual studies. Furthermore, excluding grey literature in Google Scholar decreased the risk of biases in the evaluation. 


\subsection{Data Extraction}

Extracted information included the type of the titanium substrate, electrolyte composition, $\mathrm{PEO}$ processing parameters, surface topography, $\mathrm{XRD}$ phase composition, surface content of the incorporated elements, the release profile of the metallic (i.e., $\mathrm{Ag}, \mathrm{Cu}$, and $\mathrm{Zn}$ ) ions, antibacterial assays, tested pathogens, eukaryotic cell types, and the outcomes (i.e., antibacterial behavior and cytocompatibility). The results were considered significant when $p<0.05$.

\subsection{Search Results}

A total of 1261 studies were identified in the two search engines: 1190 from Google Scholar and 71 from Scopus. After screening the titles and abstracts, 1158 studies were excluded. The primary reasons for exclusion were no antibacterial or biocompatibility tests, PEO performed in combination with other surface modification techniques, and document types: reviews, patents, conference abstracts/papers, citations and case reports. As a result, 103 studies were selected for full-text analysis. The analysis led to the exclusion of 59 studies, as they failed to meet the inclusion criteria. Finally, 49 studies were included in this systematic review and were used for a qualitative analysis of their data and for comparison with each other. A flow diagram was created to represent the entire systematic search of the relevant studies (Supplementary Figure S1). The outline of the review is presented in Figure 1.

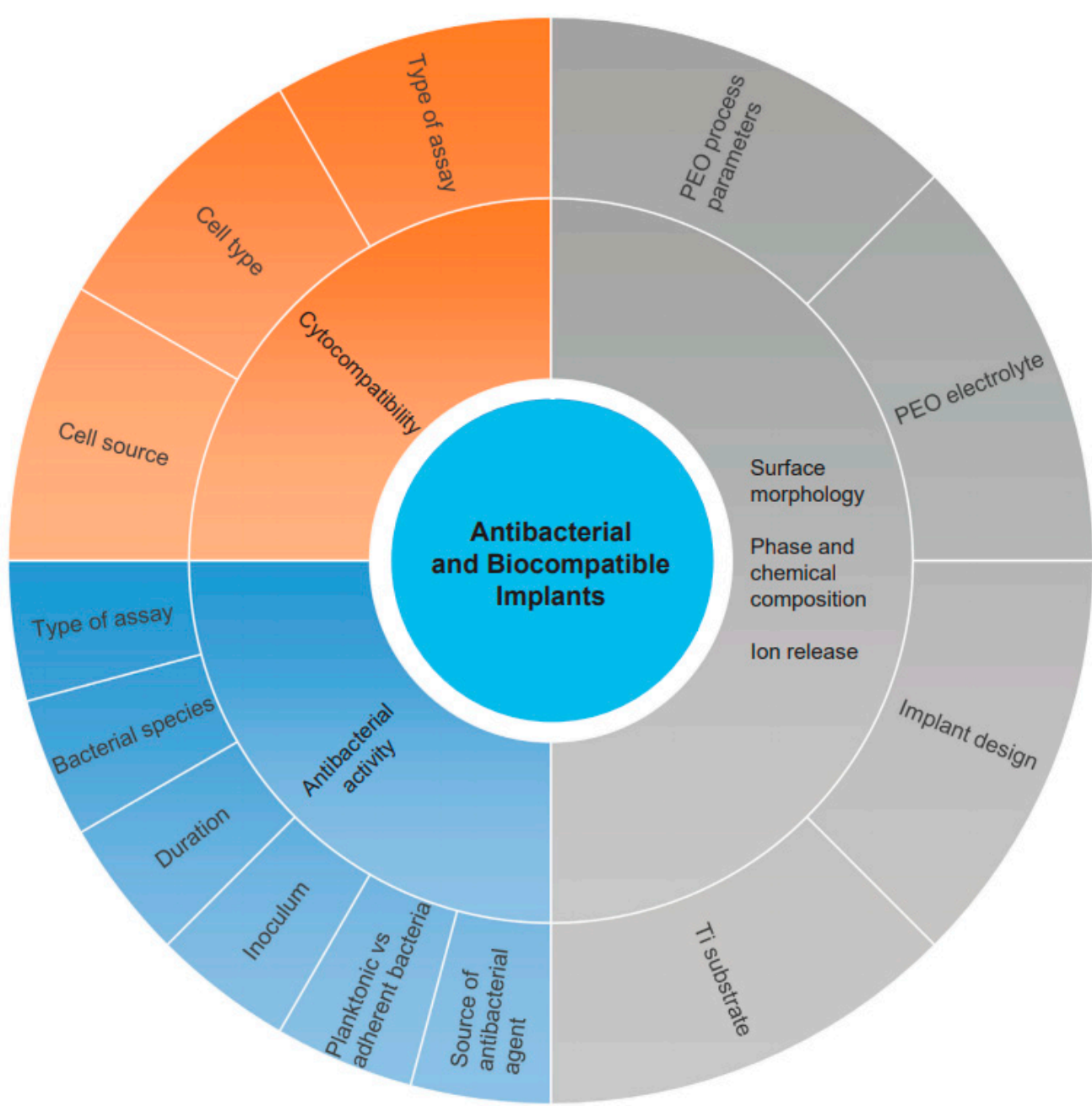

Figure 1. A graphical presentation of the outline of this systematic review. 


\section{Summary of Study Characteristics}

A summary of the study characteristics is presented in Figure 2. Of the analyzed studies, $43 \%$ used $\mathrm{Ag}$, $26 \%$ used $\mathrm{Cu}$, and $21 \%$ worked with $\mathrm{Zn}$, while $9 \%$ investigated a combination of $\mathrm{Ag}, \mathrm{Cu}$, and $\mathrm{Zn}$ (i.e., using two or more metallic agents. Various types of parameters were reported in the studies (Figure 2A), including the PEO processing parameters $(98 \%)$, phase composition $(87 \%)$, surface content of the incorporated elements $(80 \%)$, and ion release kinetics ( $48 \%$ ). Furthermore, $92 \%$ of the studies quantified the antibacterial activity, which was reported to be $>50 \%$ for $100 \%$ of the studies using $\mathrm{Ag}, 93 \%$ of the studies using $\mathrm{Cu}$, and $73 \%$ of those employing $\mathrm{Zn}$, as well as $100 \%$ of the studies combining multiple metallic agents (Figure 2B). Of those studies, $57 \%$ tested the efficacy of the surfaces against $S$. aureus, $31 \%$ of the studies tested their specimens against $E$. coli, while $12 \%$ of the studies chose other bacterial species. Furthermore, the antibacterial activity was determined against adherent bacteria in $42 \%$ of the studies, while $35 \%$ of the studies assessed the antibacterial activity of their specimens against planktonic bacteria, and $23 \%$ assessed both.

A

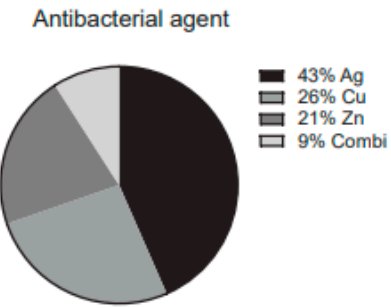

B

Antibacterial activity

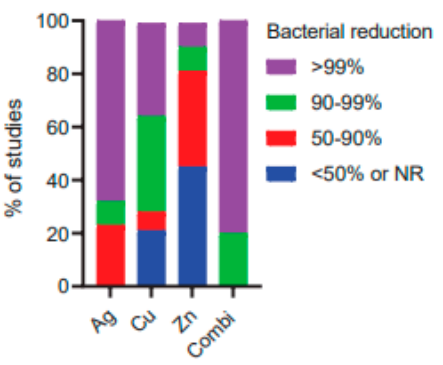

Phase composition

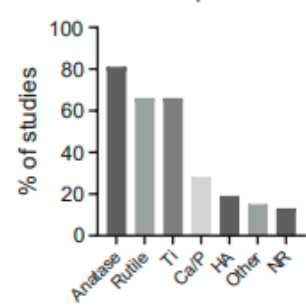

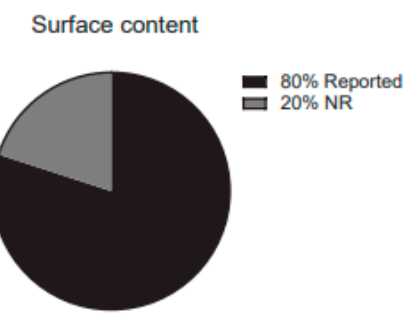

C Cytocompatibility
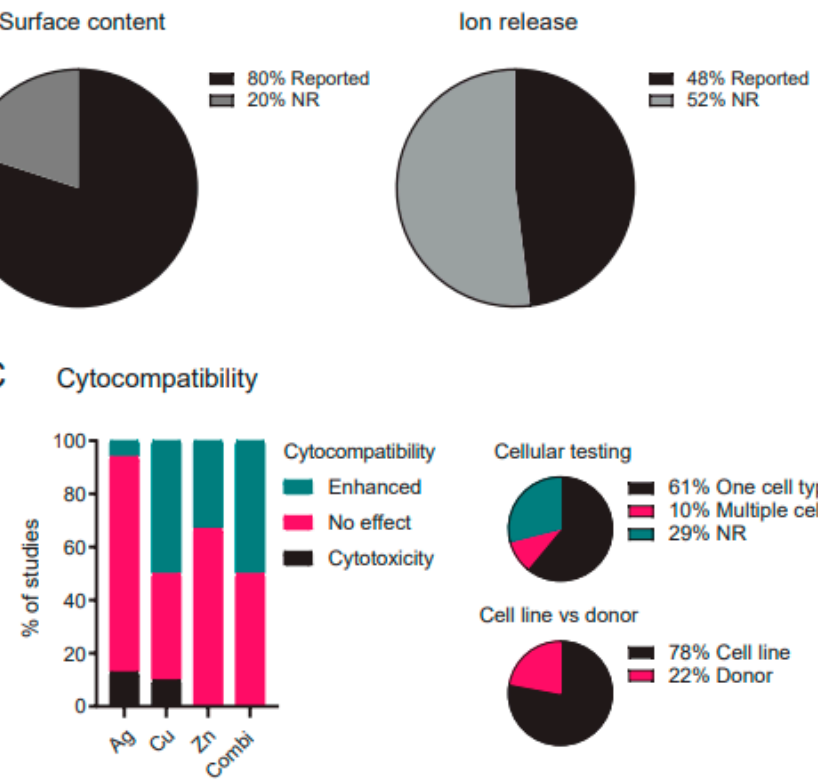

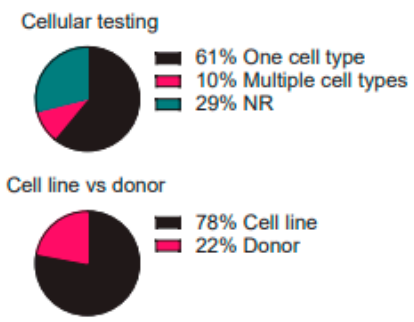

Bacterial species

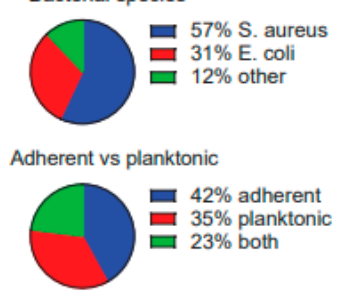

Figure 2. An overview of the (A) biomaterial, (B) antibacterial, and (C) cytocompatibility specifications of the studies included in this systematic review of the literature. Combi: combination of $\mathrm{Ag}, \mathrm{Cu}$, and/or $\mathrm{Zn}, \mathrm{HA}$ : hydroxyapatite, NR: not reported.

Cytocompatibility was tested in $71 \%$ of all studies, of which $10 \%$ tested against multiple cell types (Figure 2C). Of the studies assessing the cytocompatibility of their specimens, $78 \%$ used a cell line while $22 \%$ used cells obtained from a donor. The addition of the metallic antibacterial agent resulted in cytotoxicity for $13 \%$ of the Ag studies, $10 \%$ of the $\mathrm{Cu}$ studies, $0 \%$ of the $\mathrm{Zn}$ studies, and $0 \%$ of the studies combining two or more metals. Meanwhile, improved cell response (i.e., enhanced cell viability and/or osteogenic differentiation) was observed for $7 \%$ of the $\mathrm{Ag}$ surfaces, $50 \%$ of the $\mathrm{Cu}$ surfaces, and $33 \%$ of the $\mathrm{Zn}$ surfaces, as well as for $50 \%$ of the surfaces combining $\mathrm{Ag}$, $\mathrm{Cu}$, and $\mathrm{Zn}$.

\section{Synthesis and Characterization of PEO Biofunctionalized Surfaces}

PEO is an electrochemical process that converts the outer oxide layer of valve metals into a ceramic surface layer and is applied to enhance corrosion resistance [44], dielectric properties [45], and biocompatibility [46] of the substrates. A PEO setup has two electrodes: the cathode and anode (Figure 3A). Usually, either a constant current or voltage is applied, leading to the formation of an oxide layer on the anode (i.e., the specimen to be treated). After dielectric breakdown, the oxide layer is thickened by spark discharges that lead to 
pore formation [47] (Figure 3B). As the process continues, the sparks become more intense, resulting in the formation of larger pores.

A

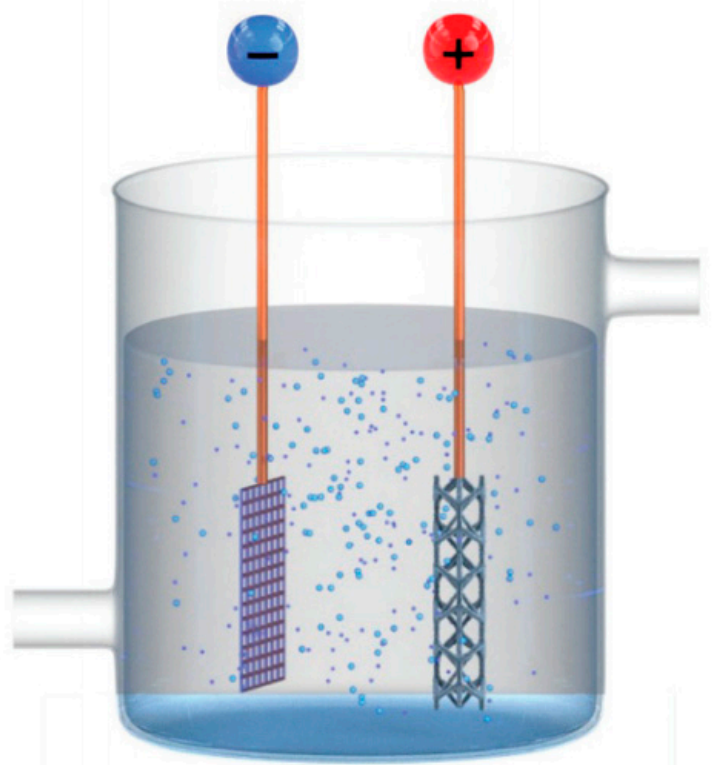

B

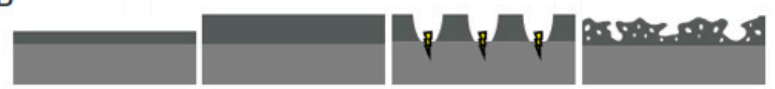

Figure 3. (A) A schematic drawing of the plasma electrolytic oxidation (PEO) setup with a cathode and an anode (implant). (B) During PEO processing, initially the titanium oxide layer grew outwards. After dielectric breakdown, plasma discharge occurred at the surface, resulting in a highly porous structure.

PEO biofunctionalization results in an altered surface morphology and chemical composition. In order to relate the antibacterial activity to certain surface characteristics, the surface of the biofunctionalized specimens is usually characterized (Tables 1-4). The important surface parameters in this regard are the surface topography, chemical composition, phase composition, and ion release profile. In the following sections, we will discuss the results regarding each of these parameters in more detail. 
Table 1. The methodological details of the included studies in which Ag was used as the antibacterial agent.

\begin{tabular}{|c|c|c|c|c|c|c|c|c|c|c|}
\hline \multicolumn{11}{|c|}{ PEO Processing Parameters } \\
\hline Substrate & $\begin{array}{c}\text { \# of Exp } \\
\text { Groups with } \\
\text { Ag }\end{array}$ & Electrolyte & Voltage (V) & $\begin{array}{l}\text { Current } \\
\text { Density } \\
\left(\mathrm{A} / \mathrm{dm}^{2}\right)\end{array}$ & Time (min) & $\begin{array}{c}\text { Surface } \\
\text { Topography }\end{array}$ & $\begin{array}{c}\text { Phase } \\
\text { Composition }\end{array}$ & $\begin{array}{c}\text { Surface } \\
\text { Content of Ag }\end{array}$ & $\begin{array}{l}\text { Cumulative Ag } \\
\text { Ion Release } \\
\text { (ppb) }\end{array}$ & Ref. \\
\hline Ti6Al4V & 2 & $\begin{array}{l}0.15 \mathrm{M} \text { CA, } 0.02 \mathrm{M} \\
\text { Ca-GP, and } 3.0 \mathrm{~g} / \mathrm{L} \\
\text { Ag NPs }\end{array}$ & - & 20 & 5 & $\begin{array}{l}\text { Micro- and } \\
\text { nano-porous } \\
\text { structures with Ag } \\
\text { NPs of } 7-25 \mathrm{~nm}\end{array}$ & $\begin{array}{l}\mathrm{Ti} \text {, anatase, } \\
\text { rutile, } \mathrm{HA}, \\
\mathrm{CaTiO} \text {, and } \\
\mathrm{Ca}_{3}\left(\mathrm{PO}_{4}\right)_{2}\end{array}$ & - & $\begin{array}{l}138 \text {-day } 28 \\
600 \text {-day } 28\end{array}$ & [31] \\
\hline Ti6Al7Nb & 1 & $\begin{array}{l}0.15 \mathrm{M} \text { CA, } 0.02 \mathrm{M} \\
\text { Ca-GP, and } 3.0 \mathrm{~g} / \mathrm{L} \\
\text { Ag NPs }\end{array}$ & - & 20 & 5 & $\begin{array}{l}\text { Porous structures } \\
(<3 \mu \mathrm{m}) \text { with Ag } \\
\text { NPs of } 37 \mathrm{~nm}\end{array}$ & $\begin{array}{l}\mathrm{Ti} \text {, anatase, and } \\
\text { rutile }\end{array}$ & $0.03 w t \%$ & - & [32] \\
\hline $\mathrm{CP}-\mathrm{Ti}$ & 3 & $\begin{array}{l}0.4 \mathrm{M} \mathrm{CA}, 0.04 \mathrm{M} \\
\beta-\mathrm{GP} \text {, and }(0.00003, \\
0.00006 \text { and } 0.004 \mathrm{M}) \\
\mathrm{AgNO}_{3}\end{array}$ & $380-420$ & - & 180 & $\begin{array}{l}\text { Irregular and rough } \\
\text { morphology with } \\
\text { spherical particles } \\
\text { and flakes }\end{array}$ & $\begin{array}{l}\text { Rutile, } \alpha-\mathrm{TCP}, \\
\beta-\mathrm{Ca}_{2} \mathrm{P}_{2} \mathrm{O}_{7} \text {, and } \\
\mathrm{HA}\end{array}$ & $\begin{array}{l}<0.1 \mathrm{wt} \% \\
<0.1 \mathrm{wt} \% \\
0.21-0.45 \mathrm{wt} \%\end{array}$ & - & [35] \\
\hline $\mathrm{CP}-\mathrm{Ti}$ & 1 & $\begin{array}{l}0.15 \mathrm{MCA}, 0.05 \mathrm{M} \\
\mathrm{NaH}_{2} \mathrm{PO}_{4}, 0.25 \mathrm{mM} \\
\mathrm{AgNO}_{3}\end{array}$ & $280-320$ & - & 6 & $\begin{array}{l}\text { Porous surface with } \\
1.5 \mu \mathrm{m} \text { pore size and } \\
8.5 \% \text { pore density }\end{array}$ & Anatase, rutile & $0.13 \mathrm{at} \%$ & 48-day 18 & [48] \\
\hline $\mathrm{CP}-\mathrm{Ti}$ & 3 & $\begin{array}{l}0.4 \mathrm{~g} / \mathrm{L} \mathrm{NaOH} \\
4.0 \mathrm{~g} / \mathrm{L} \mathrm{NaH}_{2} \mathrm{PO}_{4}, \\
\text { and } 0.1-1.0 \mathrm{~g} / \mathrm{L} \mathrm{Ag} \\
\mathrm{NPs}\end{array}$ & 400 & - & 5 & $\begin{array}{l}\text { Homogenous } \\
\text { porous surface layer }\end{array}$ & $\begin{array}{l}\mathrm{Ti} \text {, anatase, } \\
\text { rutile }\end{array}$ & $\begin{array}{l}1.5 \text { at } \% \\
3.5 \text { at } \% \\
5.8 \text { at } \%\end{array}$ & $\begin{array}{l}40-\text { day } 7 \\
200-\text { day } 7 \\
240-\text { day } 7\end{array}$ & [49] \\
\hline Ti6Al4V & 2 & $\begin{array}{l}0.15 \mathrm{M} \mathrm{CA}, 0.02 \mathrm{M} \\
\mathrm{Ca}-\mathrm{GP}, \\
0.3 \mathrm{M} \mathrm{SrA}, \text { and } \\
3.0 \mathrm{~g} / \mathrm{L} \mathrm{Ag} \mathrm{NPs}\end{array}$ & - & 20 & 5 & $\begin{array}{l}\text { Uniform coverage } \\
\text { with a } \\
\text { micro-/nanopores. } \\
\text { Addition of SrA } \\
\text { resulted in smaller } \\
\text { pore size. }\end{array}$ & $\begin{array}{l}\mathrm{Ti} \text {, anatase, } \\
\text { rutile, } \mathrm{HA}, \\
\mathrm{SrTiO}_{3} \\
\mathrm{Sr}_{2} \mathrm{Ca}\left(\mathrm{PO}_{4}\right)_{2}\end{array}$ & - & $\begin{array}{l}1500 \text {-day } 28 \\
1800 \text {-day } 28\end{array}$ & {$[50]$} \\
\hline $\mathrm{CP}-\mathrm{Ti}$ & 3 & $\begin{array}{l}100 \mathrm{mM} \mathrm{Ca}-\mathrm{GP}, \\
150 \mathrm{mM} \mathrm{CA}, 0,5 \text {, and } \\
10 \mathrm{mM} \mathrm{AgNO}_{3}\end{array}$ & - & 2.51 & 10 & $\begin{array}{l}\text { Porous oxide layer } \\
\text { for } 0 \text { and } 5 \mathrm{mM} \mathrm{Ag} \text {, } \\
\text { non-porous surface } \\
\text { for } 10 \mathrm{mM} \mathrm{Ag}\end{array}$ & Anatase, $\alpha-\mathrm{Ti}$ & $\begin{array}{l}0.5 \text { at } \% \\
1.5 \text { at } \% \\
3.0 \text { at } \%\end{array}$ & $\begin{array}{l}300-\text { day } 28 \\
3000 \text {-day } 28 \\
10^{4}-\text { day } 28\end{array}$ & [51] \\
\hline
\end{tabular}


Table 1. Cont.

\begin{tabular}{|c|c|c|c|c|c|c|c|c|c|c|}
\hline \multicolumn{11}{|c|}{ PEO Processing Parameters } \\
\hline Substrate & $\begin{array}{l}\text { \# of Exp } \\
\text { Groups with } \\
\text { Ag }\end{array}$ & Electrolyte & Voltage (V) & $\begin{array}{l}\text { Current } \\
\text { Density } \\
\left(\mathrm{A} / \mathrm{dm}^{2}\right)\end{array}$ & Time (min) & $\begin{array}{c}\text { Surface } \\
\text { Topography }\end{array}$ & $\begin{array}{c}\text { Phase } \\
\text { Composition }\end{array}$ & $\begin{array}{c}\text { Surface } \\
\text { Content of Ag }\end{array}$ & $\begin{array}{l}\text { Cumulative Ag } \\
\text { Ion Release } \\
\text { (ppb) }\end{array}$ & Ref \\
\hline $\mathrm{CP}-\mathrm{Ti}, \mathrm{Ti}-40 \mathrm{Nb}$ & 2 & $\begin{array}{l}\mathrm{Na}_{2} \mathrm{HPO}_{4}, \mathrm{NaOH}, \\
\beta-\mathrm{Ca}_{3}\left(\mathrm{PO}_{4}\right)_{2}, \text { and } \\
0.3-1 \mathrm{~g} / \mathrm{L} \mathrm{AgNO}_{3}\end{array}$ & $200-450$ & - & $5-10$ & $\begin{array}{l}\text { Uniformly } \\
\text { distributed } \beta \text {-TCP } \\
\text { particles over a } \\
\text { porous surface with } \\
0-8 \mu \mathrm{m} \text { pore sizes }\end{array}$ & $\begin{array}{l}\text { Anatase, } \alpha-\mathrm{TCP}, \\
\beta \text {-TCP }\end{array}$ & $\begin{array}{l}0.2 \text { at } \% \\
0.8 \text { at } \%\end{array}$ & - & {$[52]$} \\
\hline $\mathrm{CP}-\mathrm{Ti}$ & 4 & $\begin{array}{l}\mathrm{Na}_{2} \mathrm{HPO}_{4}, \mathrm{NaOH}, \\
\beta-\mathrm{Ca}_{3}\left(\mathrm{PO}_{4}\right)_{2} \text {, and } \\
1 \mathrm{~g} / \mathrm{L} \mathrm{AgNO}_{3}\end{array}$ & $200-450$ & - & $5-10$ & $\begin{array}{l}\text { Uniformly } \\
\text { distributed } \beta-\mathrm{TCP} \\
\text { particles over a } \\
\text { porous surface with } \\
0-8 \mu \mathrm{m} \text { pore sizes }\end{array}$ & $\begin{array}{l}\text { Anatase, } \alpha \text {-TCP, } \\
\beta \text {-TCP }\end{array}$ & $\begin{array}{l}0.3 \mathrm{at} \% \\
0.5 \mathrm{at} \% \\
0.8 \mathrm{at} \%\end{array}$ & - & {$[53]$} \\
\hline $\mathrm{CP}-\mathrm{Ti}$ & 3 & $\begin{array}{l}0.1 \mathrm{MCA}, 0.06 \mathrm{M} \\
\mathrm{NaH}_{2} \mathrm{P} \text {, and } \\
0.01-0.05 \mathrm{M} \mathrm{Ag}_{2} \mathrm{O} \\
\mathrm{NPs}\end{array}$ & - & 10 & 10 & $\begin{array}{l}\text { Porous structure } \\
\text { with typical } \\
\text { micro-sized pores }\end{array}$ & Anatase, rutile & $\begin{array}{l}1.6 \mathrm{wt} \% \\
3.1 \mathrm{wt} \% \\
5.8 \mathrm{wt} \%\end{array}$ & $\begin{array}{l}2000 \text {-day } 28 \\
4000 \text {-day } 28 \\
10^{4} \text {-day } 28\end{array}$ & {$[54]$} \\
\hline $\mathrm{CP}-\mathrm{Ti}$ & 1 & $\begin{array}{l}\mathrm{CA}, \mathrm{Na}_{2} \mathrm{HPO}_{4} \text {, and } \\
0.0025 \mathrm{M} \mathrm{Ag}-\mathrm{A}\end{array}$ & 380 & - & 5 & $\begin{array}{l}\text { Flake-like } \\
\text { morphology with } \\
\text { regional Ag particles } \\
\text { of }<200 \mathrm{~nm}\end{array}$ & $\begin{array}{l}\mathrm{Ti} \text {, anatase, } \\
\text { rutile, } \\
\mathrm{HA} \text {, and } \mathrm{CaTiO} 3\end{array}$ & $4.6 w t \%$ & - & [55] \\
\hline $\mathrm{CP}-\mathrm{Ti}$ & 3 & $\begin{array}{l}20.5 \mathrm{~g} / \mathrm{L} \mathrm{CA}, 7.2 \\
\mathrm{G} / \mathrm{L} \mathrm{Na}_{2} \mathrm{HPO}_{4} \text {, and } \\
(0.0005,0.001, \text { and } \\
0.002) \mathrm{M} \mathrm{Ag-A}\end{array}$ & 400 & - & 5 & $\begin{array}{l}\text { Micro-porous } \\
\text { structures with Ag } \\
\text { NPs surrounding } \\
\text { micro-pores }\end{array}$ & $\begin{array}{l}\mathrm{Ti} \text {, anatase, } \\
\text { rutile, } \\
\mathrm{HA} \text {, and } \mathrm{CaTiO} 3\end{array}$ & $1.14 \mathrm{wt} \%$ & - & {$[56]$} \\
\hline Ti6Al4V & 1 & $\begin{array}{l}20.5 \mathrm{~g} / \mathrm{L} \mathrm{CA}, 7.2 \mathrm{~g} / \mathrm{L} \\
\mathrm{Na}_{2} \mathrm{HPO}_{4} \text {, and } \\
0.001 \mathrm{M} \mathrm{Ag}^{-\mathrm{A}}\end{array}$ & 400 & - & 5 & $\begin{array}{l}\text { Micro-porous } \\
\text { structures with Ag } \\
\mathrm{NPs} \text { of }<100 \mathrm{~nm} \\
\text { surrounding } \\
\text { micro-pores }\end{array}$ & $\begin{array}{l}\text { Ti, anatase, } \\
\text { rutile, HA, and } \\
\text { CaTiO3 }\end{array}$ & $0.7 \mathrm{wt} \%$ & 1500 —day 14 & {$[57]$} \\
\hline Ti6Al4V & 2 & $\begin{array}{l}\mathrm{CA}, \beta-\mathrm{GP} \text { and }(0.1 \\
\text { and } 0.4) \mathrm{g} / \mathrm{L} \mathrm{AgNO}_{3}\end{array}$ & 400 & - & 5 & $\begin{array}{l}\text { Granular and } \\
\text { needle-like } \\
\text { morphology with } \\
\text { Ag NPs of 20-30 nm }\end{array}$ & $\begin{array}{l}\mathrm{Ti} \text {, anatase, } \\
\text { rutile, } \mathrm{HA} \text {, and } \\
\mathrm{CaTiO}_{3}\end{array}$ & $\begin{array}{l}0.6 w t \% \\
2.1 w t \%\end{array}$ & $\begin{array}{l}\text { 2500—day } 14 \\
8000 \text {-day } 14\end{array}$ & {$[58]$} \\
\hline $\begin{array}{l}\mathrm{Ti}-29 \mathrm{Nb}-13 \mathrm{Ta}- \\
4.6 \mathrm{Zr}\end{array}$ & 2 & $\begin{array}{l}0.15 \mathrm{M} \mathrm{CA}, 0.1 \mathrm{M} \\
\text { Ca-GP, and }(0.0005 \\
\text { and } 0.0025) \mathrm{M} \\
\mathrm{AgNO}_{3}\end{array}$ & - & 2.51 & 10 & $\begin{array}{l}\text { Porous structures } \\
(<10 \mu \mathrm{m})\end{array}$ & - & $\begin{array}{l}0.01 \mathrm{wt} \% \\
0.01 \mathrm{wt} \%\end{array}$ & - & [59] \\
\hline
\end{tabular}


Table 1. Cont.

\begin{tabular}{|c|c|c|c|c|c|c|c|c|c|c|}
\hline \multicolumn{11}{|c|}{ PEO Processing Parameters } \\
\hline Substrate & $\begin{array}{c}\text { \# of Exp } \\
\text { Groups with } \\
\text { Ag }\end{array}$ & Electrolyte & Voltage (V) & $\begin{array}{l}\text { Current } \\
\text { Density } \\
\left(\mathrm{A} / \mathrm{dm}^{2}\right)\end{array}$ & Time (min) & $\begin{array}{c}\text { Surface } \\
\text { Topography }\end{array}$ & $\begin{array}{c}\text { Phase } \\
\text { Composition }\end{array}$ & $\begin{array}{c}\text { Surface } \\
\text { Content of Ag }\end{array}$ & $\begin{array}{c}\text { Cumulative Ag } \\
\text { Ion Release } \\
\text { (ppb) }\end{array}$ & Ref. \\
\hline CP-Ti & 3 & $\begin{array}{l}0.1 \mathrm{M} \mathrm{KOH}, 0.015 \mathrm{M} \\
\mathrm{K}_{4} \mathrm{P}_{2} \mathrm{O}_{7} \text {, and }(0.1,0.3 \\
\text { and } 0.5) \mathrm{g} / \mathrm{L} \mathrm{Ag} \mathrm{NPs}\end{array}$ & - & 10 & 5 & $\begin{array}{l}\text { Micro-porous } \\
\text { structures with Ag } \\
\text { NPs of }<20 \mathrm{~nm} \\
(3-7.5 \mu \mathrm{m})\end{array}$ & - & $\begin{array}{l}0.53 \text { at } \% \\
0.69 \text { at } \% \\
0.80 \text { at } \%\end{array}$ & $\begin{array}{l}12.2 \text { - day } 1 \\
22.7 \text { - day } 1 \\
28.8 \text {-day } 1\end{array}$ & [60] \\
\hline CP-Ti & 1 & $\begin{array}{l}0.3 \mathrm{M} \text { CA, } 0.02 \mathrm{M} \mathrm{GP} \text {, } \\
\text { and } 0.62 \mathrm{~g} / \mathrm{L} \mathrm{Ag} \\
\mathrm{NPs}\end{array}$ & 290 & - & 10 & $\begin{array}{l}\text { Porous structures } \\
\text { with volcano } \\
\text { top-like micro-pores }\end{array}$ & $\begin{array}{l}\text { Ti, anatase, and } \\
\text { rutile }\end{array}$ & 1.07 at $\%$ & - & [61] \\
\hline CP-Ti & 1 & $\begin{array}{l}0.3 \mathrm{M} \text { CA, } 0.02 \mathrm{M} \mathrm{GP} \text {, } \\
\text { and } 0.62 \mathrm{~g} / \mathrm{L} \mathrm{Ag} \\
\mathrm{NPs}\end{array}$ & 290 & - & 10 & $\begin{array}{l}\text { Porous structures } \\
\text { with Ag NPs of } \\
<100 \mathrm{~nm}\end{array}$ & $\begin{array}{l}\text { Ti, anatase, and } \\
\text { rutile }\end{array}$ & - & - & [62] \\
\hline Ti6Al4V & 1 & $\begin{array}{l}\text { Pure water and } \\
\text { AgPURE }{ }^{\mathrm{TM}} \text { W10 } \\
\text { nanosilver } \\
\text { suspension }\end{array}$ & - & 20 & 0.5 & $\begin{array}{l}\text { Flake-like } \\
\text { morphology with } \\
\text { Ag particles of } \\
<200 \mathrm{~nm}\end{array}$ & - & 3.6 at $\%$ & - & [63] \\
\hline Ti6Al4V & 2 & $\begin{array}{l}0.2 \mathrm{M} \mathrm{CA}, 0.02 \mathrm{M} \\
\beta \text {-GP, and }(0.005 \text { and } \\
0.05) \mathrm{g} / \mathrm{L} \mathrm{Ag} \mathrm{NPs}\end{array}$ & $\begin{array}{l}387 \pm 3 \\
385 \pm 2 \\
\end{array}$ & 8 & 3 & $\begin{array}{l}\text { Porous structures } \\
\text { with volcano } \\
\text { top-like micro-pores } \\
(<3 \mu \mathrm{m})\end{array}$ & $\begin{array}{l}\text { Ti, rutile, and } \\
\mathrm{HA}\end{array}$ & $\begin{array}{l}<0.1 \mathrm{wt} \% \\
<0.1 \mathrm{wt} \%\end{array}$ & - & [64] \\
\hline $\mathrm{CP}-\mathrm{Ti}$ & 3 & $\begin{array}{l}2.0 \mathrm{~g} / \mathrm{L} \\
\mathrm{NaH}_{2} \mathrm{PO}_{4} \cdot 2 \mathrm{H}_{2} \mathrm{O}, 5.0 \\
\mathrm{~g} / \mathrm{L} \mathrm{CA} \text {, and } 0.1,0.5, \\
\text { and } 0.8 \mathrm{~g} / \mathrm{L} \mathrm{Ag-A}\end{array}$ & 500 & - & 5 & $\begin{array}{l}\text { Porous structures } \\
\text { uniformly covering } \\
\text { surface }\end{array}$ & $\begin{array}{l}\mathrm{Ti} \text {, anatase, } \\
\text { rutile, } \mathrm{HA}, \\
\mathrm{CaTiO}_{3}\end{array}$ & $\begin{array}{l}0.8 \mathrm{at} \% \\
1.5 \mathrm{at} \% \\
2.2 \mathrm{at} \%\end{array}$ & $\begin{array}{l}264 \text {-day } 7 \\
813 \text {-day } 7 \\
1110 \text {-day } 7\end{array}$ & [65] \\
\hline CP-Ti & 2 & $\begin{array}{l}\mathrm{NTA}, \mathrm{Ca}(\mathrm{OH})_{2}, \text { and } \\
180 \mathrm{mg} / \mathrm{L} \mathrm{Ag} \mathrm{NPs}\end{array}$ & $250-300$ & - & 5 & $\begin{array}{l}\text { Rough, thick oxide } \\
\text { layer } \\
\text { with a highly porous } \\
\text { structure }\end{array}$ & - & $\begin{array}{l}0.3 w t \% \\
0.7 w t \%\end{array}$ & - & [66] \\
\hline
\end{tabular}

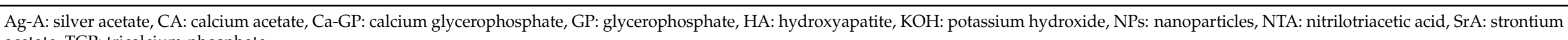
acetate, TCP: tricalcium phosphate. 
Table 2. The methodological details of the included studies in which $\mathrm{Cu}$ was used as the antibacterial agent.

\begin{tabular}{|c|c|c|c|c|c|c|c|c|c|c|}
\hline \multicolumn{11}{|c|}{ PEO Processing Parameters } \\
\hline Substrate & $\begin{array}{l}\text { \# of Exp } \\
\text { Groups with } \\
\text { Cu }\end{array}$ & Electrolyte & Voltage (V) & $\begin{array}{l}\text { Current } \\
\text { Density } \\
\left(\mathrm{A} / \mathrm{dm}^{2}\right)\end{array}$ & $\begin{array}{l}\text { Time } \\
\text { (min) }\end{array}$ & Surface Topography & $\begin{array}{c}\text { Phase } \\
\text { Composition }\end{array}$ & $\begin{array}{c}\text { Surface } \\
\text { Content of } \mathrm{Cu}\end{array}$ & $\begin{array}{c}\text { Cumulative Cu } \\
\text { Ion } \\
\text { Release (ppb) }\end{array}$ & Ref \\
\hline $\mathrm{CP}-\mathrm{Ti}, \mathrm{Ti}-40 \mathrm{Nb}$ & 2 & $\begin{array}{l}\mathrm{H}_{3} \mathrm{PO}_{4}, 50-75 \mathrm{~g} / \mathrm{L} \\
\mathrm{CaCO}, 40-60 \mathrm{~g} / \mathrm{L} \\
\text { Cu-substituted HA }\end{array}$ & $200-450$ & - & $5-10$ & $\begin{array}{l}\text { Uniformly distributed } \\
\beta \text {-TCP particles over a } \\
\text { porous } \\
\text { coating surface with } \\
0-8 \mu \mathrm{m} \text { pore sizes. }\end{array}$ & $\begin{array}{l}\text { Anatase, } \beta-\mathrm{TCP}, \\
\alpha-\mathrm{TCP}, \mathrm{Ca}_{2} \mathrm{P}_{2} \mathrm{O}_{7}\end{array}$ & $\begin{array}{l}0.1 \text { at } \% \\
0.2 \text { at } \%\end{array}$ & - & {$[52]$} \\
\hline CP-Ti & 1 & $\begin{array}{l}0.02 \mathrm{M} \mathrm{C}_{12} \mathrm{H}_{22} \mathrm{CaO}_{14} \\
0.01 \mathrm{M}\left(\mathrm{NaPO}_{3}\right)_{6} \\
0.02 \mathrm{M} \mathrm{C}_{12} \mathrm{H}_{22} \mathrm{CuO}_{14}\end{array}$ & NR & NR & 6 & $\begin{array}{l}\text { Porous surface with } \\
\text { irregularly shaped and } \\
\text { sized pores }\end{array}$ & - & - & - & [67] \\
\hline CP-Ti & 2 & $\begin{array}{l}0.1 \mathrm{M} \mathrm{CA}, 0.06 \mathrm{M} \\
\mathrm{NaH}_{2} \mathrm{P}, 5-10 \mathrm{~g} / \mathrm{L} \\
\mathrm{Na}_{2} \mathrm{Cu}-\mathrm{EDTA}\end{array}$ & - & 10 & 10 & $\begin{array}{l}\text { Highly porous area } \\
\text { with micro-sized pores } \\
\text { and a rough less } \\
\text { porous area }\end{array}$ & - & $\begin{array}{l}2.3 \mathrm{wt} \% \\
4.2 \mathrm{wt} \%\end{array}$ & $\begin{array}{l}3.3 / \mathrm{cm}^{2}-\text { day } 8 \\
8.1 / \mathrm{cm}^{2}- \\
\text { day } 8\end{array}$ & {$[68]$} \\
\hline Ti6Al4V & 2 & $\begin{array}{l}11 \mathrm{~g} / \mathrm{L} \mathrm{KOH}, 10 \mathrm{~g} / \mathrm{L} \\
\text { EDTA-CuNa } 2,5 \text { or } \\
15 \mathrm{~g} / \mathrm{L} \text { phytic acid }\end{array}$ & - & 10 & 3 & $\begin{array}{l}\text { Uniformly distributed } \\
\text { three-dimensional } \\
\text { porous structure }\end{array}$ & $\begin{array}{l}\text { Anatase, rutile, } \\
\text { and } \mathrm{TiP}_{2} \mathrm{O}_{7}\end{array}$ & $\begin{array}{l}1.01 \mathrm{wt} \% \\
1.92 \mathrm{wt} \%\end{array}$ & $\begin{array}{l}\text { 192—day } 8 \\
197 \text {-day } 8\end{array}$ & {$[70]$} \\
\hline CP-Ti & 1 & $\begin{array}{l}0.2 \mathrm{MCA} \\
\text { monohydrate, } 0.02 \mathrm{M} \\
\mathrm{NaH}_{2} \mathrm{PO}_{4}, 0.01 \mathrm{M} \mathrm{CuA} \\
\text { monohydrate }\end{array}$ & - & 3.25 & 5 & $\begin{array}{l}\text { Volcanic uniform } \\
\text { porous morphology } \\
\text { with } 1-5 \mu \mathrm{m} \text { pores }\end{array}$ & $\begin{array}{l}\text { Ti, rutile, } \\
\text { anatase, } \\
\mathrm{Ca}_{3}\left(\mathrm{PO}_{4}\right)_{2}\end{array}$ & 5.05 at $\%$ & 32.8—day 14 & {$[71]$} \\
\hline CP-Ti & 4 & $\begin{array}{l}0.2 \mathrm{M} \mathrm{CA}, 0.02 \mathrm{M} \\
\beta-\mathrm{GP} \text {, and }(0.00125 \\
0.0025,0.00375, \text { and } \\
0.005) \mathrm{M} \mathrm{Cu}(\mathrm{OAc})_{2}\end{array}$ & 450 & - & 1.5 & $\begin{array}{l}\text { Micro-porous } \\
\text { structures } \\
(1-4 \mu \mathrm{m})\end{array}$ & $\begin{array}{l}\mathrm{Ti} \text {, anatase, and } \\
\text { rutile }\end{array}$ & $\begin{array}{l}0.67 w \mathrm{wt} \% \\
1.17 \mathrm{wt} \% \\
1.51 \mathrm{wt} \% \\
1.93 \mathrm{wt} \% \\
\end{array}$ & $\begin{array}{l}\text { 6.75-day } 21 \\
- \\
- \\
60.2 \text {-day } 21\end{array}$ & {$[72]$} \\
\hline CP-Ti & 2 & $\begin{array}{l}0.1 \mathrm{M} \mathrm{Na}_{2}, 0.25 \mathrm{M} \\
\mathrm{NaOH}, 0.1 \mathrm{M} \mathrm{CA} \text {, } \\
0.02 \mathrm{M} \mathrm{Na} \mathrm{SiO}_{3} \text {, and } \\
(0.0002 \text { and } 0.002) \mathrm{M} \\
\mathrm{CuSO}_{4}\end{array}$ & 250 & - & 5 & $\begin{array}{l}\text { Macro-pores or crater } \\
\text { structures }(>100 \mu \mathrm{m}) \\
\text { with nano-grains }\end{array}$ & - & - & $\begin{array}{l}\text { 411.3—day } 2 \\
27.0 \text {-day } 2\end{array}$ & [73] \\
\hline
\end{tabular}


Table 2. Cont.

\begin{tabular}{|c|c|c|c|c|c|c|c|c|c|c|}
\hline \multicolumn{11}{|c|}{ PEO Processing Parameters } \\
\hline Substrate & $\begin{array}{c}\text { \# of Exp } \\
\text { Groups with } \\
\text { Cu }\end{array}$ & Electrolyte & Voltage (V) & $\begin{array}{l}\text { Current } \\
\text { Density } \\
\left(\mathrm{A} / \mathrm{dm}^{2}\right)\end{array}$ & $\begin{array}{l}\text { Time } \\
(\mathrm{min})\end{array}$ & Surface Topography & $\begin{array}{c}\text { Phase } \\
\text { Composition }\end{array}$ & $\begin{array}{c}\text { Surface } \\
\text { Content of } \mathrm{Cu}\end{array}$ & $\begin{array}{l}\text { Cumulative Cu } \\
\text { Ion } \\
\text { Release (ppb) }\end{array}$ & Ref. \\
\hline $\mathrm{CP}-\mathrm{Ti}$ & 2 & $\begin{array}{l}15 \mathrm{~g} \cdot \mathrm{L}-1 \mathrm{NaH}_{2} \mathrm{PO}_{4}, \\
2 \mathrm{~g} / \mathrm{L} \mathrm{NaOH} \text { and }(0.3 \\
\text { and 3.0) } \mathrm{g} / \mathrm{L} \mathrm{Cu} \mathrm{NPs}\end{array}$ & $\begin{array}{l}470 \pm 3 \\
465 \pm 3\end{array}$ & 20 & 5 & $\begin{array}{l}\text { Micro-porous } \\
\text { structures } \\
(1-5 \mu \mathrm{m})\end{array}$ & $\mathrm{Ti}$, anatase & $\begin{array}{l}1.30 \text { at } \% \\
2.76 \text { at } \%\end{array}$ & $\begin{array}{l}0.117 \text { —day } 1 \\
0.135 \text { —day } 1\end{array}$ & [75] \\
\hline Ti6Al4V & 3 & $\begin{array}{l}\text { Phosphate electrolyte } \\
\text { with }(2,6 \text { and } 10) \mathrm{g} / \mathrm{L} \\
\mathrm{Cu}_{2} \mathrm{O} \text { NPs }\end{array}$ & 450 & - & 15 & $\begin{array}{l}\text { Micro-porous } \\
\text { structures }(<30 \mu \mathrm{m}) \\
\text { with } \mathrm{Cu}_{2} \mathrm{O} \text { NPs of } \\
20-30 \mathrm{~nm}\end{array}$ & $\begin{array}{l}\text { Ti, anatase, } \\
\text { rutile, } \mathrm{Cu}, \mathrm{Cu}_{2} \mathrm{O} \text {, } \\
\text { and } \mathrm{CuO}\end{array}$ & $\begin{array}{l}16.0 \mathrm{wt} \% \\
23.2 \mathrm{wt} \% \\
24.5 \mathrm{wt} \%\end{array}$ & - & [76] \\
\hline CP-Ti & 1 & $\begin{array}{l}0.002 \mathrm{M} \mathrm{CA}, 0.02 \mathrm{M} \\
\beta-\mathrm{GP}, \text { and } 0.0013 \mathrm{M} \\
\mathrm{Cu}(\mathrm{OAc})_{2}\end{array}$ & 480 & - & 2 & $\begin{array}{l}\text { Micro-porous } \\
\text { structures } \\
(1-4 \mu \mathrm{m})\end{array}$ & $\begin{array}{l}\text { Ti, anatase, and } \\
\text { rutile }\end{array}$ & $0.77 w \mathrm{t} \%$ & 4.5 -day 7 & [77] \\
\hline Ti6Al4V & 1 & $\begin{array}{l}50 \mathrm{~g} / \mathrm{L} \mathrm{Na}_{2} \mathrm{SiO}_{3} \text { and } \\
4 \mathrm{~g} / \mathrm{L} \mathrm{Cu}_{2} \mathrm{O} \text { NPs }\end{array}$ & 350 & - & 15 & $\begin{array}{l}\text { Porous structures } \\
(<3 \mu \mathrm{m}) \text { with } \mathrm{Cu}_{2} \mathrm{O} \\
\mathrm{NPs} \text { of } 20-50 \mathrm{~nm}\end{array}$ & $\begin{array}{l}\text { Ti, anatase, } \\
\text { rutile, } \mathrm{Cu}, \mathrm{Cu}_{2} \mathrm{O} \text {, } \\
\text { and } \mathrm{CuO}\end{array}$ & $27.27 \mathrm{wt} \%$ & - & [78] \\
\hline
\end{tabular}

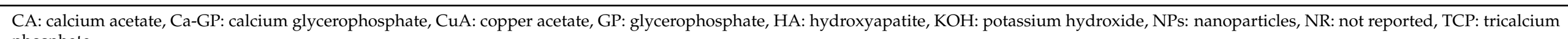
phosphate. 
Table 3. The methodological details of the included studies in which $\mathrm{Zn}$ was used as the antibacterial agent.

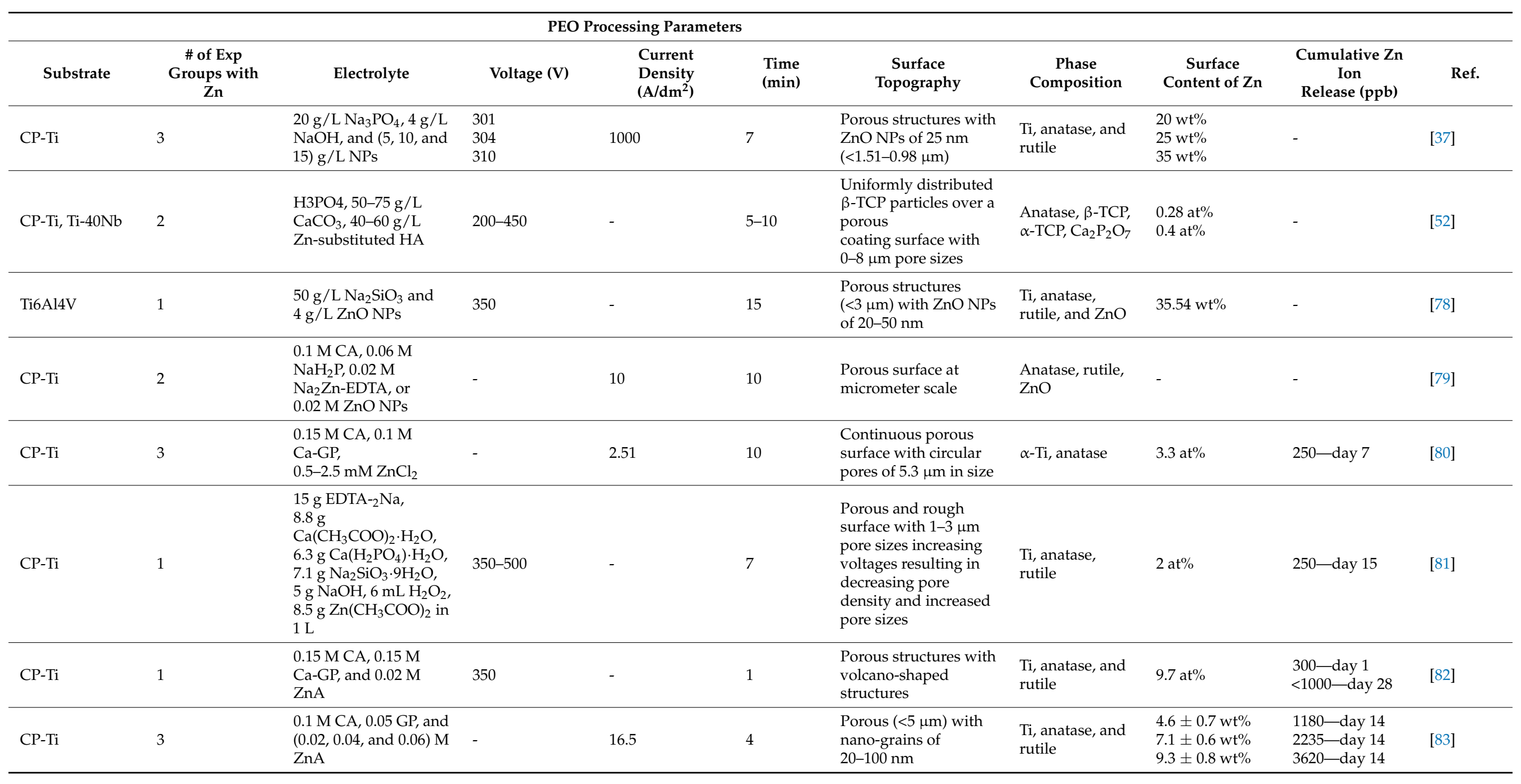


Table 3. Cont.

\begin{tabular}{|c|c|c|c|c|c|c|c|c|c|c|}
\hline \multicolumn{11}{|c|}{ PEO Processing Parameters } \\
\hline Substrate & $\begin{array}{c}\text { \# of Exp } \\
\text { Groups with } \\
\text { Zn }\end{array}$ & Electrolyte & Voltage (V) & $\begin{array}{l}\text { Current } \\
\text { Density } \\
\left(\mathrm{A} / \mathrm{dm}^{2}\right)\end{array}$ & $\begin{array}{l}\text { Time } \\
\text { (min) }\end{array}$ & $\begin{array}{c}\text { Surface } \\
\text { Topography }\end{array}$ & $\begin{array}{c}\text { Phase } \\
\text { Composition }\end{array}$ & $\begin{array}{c}\text { Surface } \\
\text { Content of } \mathrm{Zn}\end{array}$ & $\begin{array}{c}\text { Cumulative Zn } \\
\text { Ion } \\
\text { Release (ppb) }\end{array}$ & Ref. \\
\hline CP-Ti & 3 & $\begin{array}{l}0.1 \mathrm{M} \mathrm{CA}, 0.025 \mathrm{M} \\
\mathrm{Na}_{5} \mathrm{P}_{3} \mathrm{O}_{10} \text { and }(0.01 \\
0.03 \text {, and } 0.05) \mathrm{M} \mathrm{ZnA}\end{array}$ & 380 & - & 20 & $\begin{array}{l}\text { Micro-porous } \\
\text { structures }\end{array}$ & - & $\begin{array}{l}0.199 \text { at } \% \\
0.574 \text { at } \% \\
1.995 \text { at } \%\end{array}$ & - & [85] \\
\hline Ti-15Mo & 3 & $\begin{array}{l}0.1 \mathrm{M} \mathrm{Ca}\left(\mathrm{H}_{2} \mathrm{PO}_{2}\right)_{2} \\
10 \mathrm{~g} / \mathrm{L} \mathrm{ZnO} \text {, or } 25 \mathrm{~g} / \mathrm{L} \\
\mathrm{Zn} 3\left(\mathrm{PO}_{4}\right)_{2} \text { or } 10 \mathrm{~g} / \mathrm{L} \\
\mathrm{Ca}_{3}\left(\mathrm{PO}_{4}\right)_{2} \text { and } 10 \mathrm{~g} / \mathrm{L} \\
\mathrm{Zn}_{3}\left(\mathrm{PO}_{4}\right)_{2} \text { particles }\end{array}$ & 300 & 15 & 5 & $\begin{array}{l}\text { Porous oxide layer } \\
\text { with micropores }\end{array}$ & - & $\begin{array}{l}1.5 \text { at } \% \\
1.1 \text { at } \% \\
0.2 \text { at } \%\end{array}$ & $\begin{array}{l}\text { 115-week } 16 \\
64 \text {-week } 16 \\
60 \text {-week } 16\end{array}$ & [86] \\
\hline
\end{tabular}

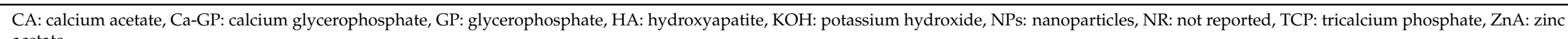
acetate. 
Table 4. The methodological details of the included studies in which multiple antibacterial agents were used.

\begin{tabular}{|c|c|c|c|c|c|c|c|c|c|c|}
\hline \multicolumn{11}{|c|}{ PEO Processing Parameters } \\
\hline Substrate & \# of Exp groups & Electrolyte & Voltage (V) & $\begin{array}{l}\text { Current Density } \\
\left(\mathbf{A} / \mathrm{dm}^{2}\right)\end{array}$ & Time (min) & $\begin{array}{c}\text { Surface } \\
\text { Topography }\end{array}$ & $\begin{array}{c}\text { Phase } \\
\text { Composition }\end{array}$ & $\begin{array}{c}\text { Surface } \\
\text { Content of } \mathrm{Zn}\end{array}$ & $\begin{array}{l}\text { Cumulative Ion } \\
\text { Release (ppb) }\end{array}$ & Ref. \\
\hline \multicolumn{11}{|c|}{$\mathrm{Ag}$ and $\mathrm{Cu}$} \\
\hline Ti6Al4V & 6 & $\begin{array}{l}0.15 \mathrm{M} \mathrm{CA}, 0.02 \mathrm{M} \\
\mathrm{Ca}-\mathrm{GP}, \\
0.75-3.0 \mathrm{~g} / \mathrm{L} \mathrm{Ag} \text {, } \\
\text { and/or Cu NPs in } \\
\text { ratios } 0-100 \%\end{array}$ & - & 20 & 5 & $\begin{array}{l}\text { Homogeneous } \\
\text { porous surface } \\
\text { with circular pores. } \\
\text { Ag and/or } \mathrm{Cu} \\
\text { NPs scattered on } \\
\text { surface. }\end{array}$ & - & - & $\begin{array}{l}\text { Day 28: } \\
1491(\mathrm{Ag}) /- \\
1906(\mathrm{Ag}) /- \\
1573(\mathrm{Ag}) / 1527(\mathrm{Cu}) \\
1425(\mathrm{Ag}) / 1392(\mathrm{Cu}) \\
1291(\mathrm{Ag}) / 1225(\mathrm{Cu}) \\
-/ 1981(\mathrm{Cu})\end{array}$ & [19] \\
\hline Ti6Al4V & 6 & $\begin{array}{l}0.15 \mathrm{M} \mathrm{CA}, 0.02 \mathrm{M} \\
\mathrm{Ca}-\mathrm{GP}, \\
0.75-3.0 \mathrm{~g} / \mathrm{L} \mathrm{Ag} \text {, } \\
\text { and } / \text { or } \mathrm{Zn} \mathrm{NPs} \mathrm{in} \\
\text { ratios } 0-100 \%\end{array}$ & - & 20 & 5 & $\begin{array}{l}\text { Homogeneous } \\
\text { porous surface } \\
\text { with circular pores. } \\
\text { Ag and/or Zn } \\
\text { NPs scattered on } \\
\text { surface. }\end{array}$ & - & - & $\begin{array}{l}\text { Day 28: } \\
1491(\mathrm{Ag}) /- \\
1906(\mathrm{Ag}) /- \\
1573(\mathrm{Ag}) / 1467(\mathrm{Zn}) \\
1682(\mathrm{Ag}) / 1697(\mathrm{Zn}) \\
1749(\mathrm{Ag}) / 1678(\mathrm{Zn}) \\
-/ 2281(\mathrm{Zn})\end{array}$ & [20] \\
\hline $\mathrm{CP}-\mathrm{Ti}$ & 3 & $\begin{array}{l}0.1 \mathrm{M} \mathrm{CA}, 0.02 \mathrm{M} \\
\beta-G P, 0.25 \mathrm{~g} \cdot \mathrm{L}-1 \\
\text { SDBS, } 0.1 \mathrm{M} \mathrm{ZnA,} \\
\text { and } 6 \mathrm{~g} / \mathrm{L} \text { Ag NPs }\end{array}$ & 390 & - & $\begin{array}{l}0.5 \\
1.5 \\
2\end{array}$ & $\begin{array}{l}\text { Micro-porous } \\
\text { structures with } \\
\text { nano-grains of } \\
5-40 \mathrm{~nm} \text { and Ag } \\
\text { NPs of }<20 \mathrm{~nm} \\
(1-4 \mu \mathrm{m}) \\
\end{array}$ & $\begin{array}{l}\mathrm{Ti} \text {, anatase, rutile, } \\
\text { and } \mathrm{ZnO}\end{array}$ & $\begin{array}{l}1.06(\mathrm{Ag}) / 22.19(\mathrm{Zn}) \\
1.42(\mathrm{Ag}) / 26.93(\mathrm{Zn}) \\
1.56(\mathrm{Ag}) / 29.38(\mathrm{Zn})\end{array}$ & $\begin{array}{l}\text { Week } 36 \\
- \\
- \\
684(\mathrm{Ag}) / 6880(\mathrm{Zn})\end{array}$ & [87] \\
\hline \multicolumn{11}{|c|}{$\mathrm{Cu}$ and $\mathrm{Zn}$} \\
\hline $\mathrm{CP}-\mathrm{Ti}$ & 5 & $\begin{array}{l}0.002 \mathrm{M} \mathrm{CA}, 0.02 \\
\mathrm{M} \beta-\mathrm{GP},(0,0.005, \\
0.01,0.02, \text { and } \\
0.04) \mathrm{M} \mathrm{ZnA} \text { and } \\
0.0013 \mathrm{M} \\
\mathrm{Cu}(\mathrm{OAc})_{2} \\
\end{array}$ & 480 & - & 2 & $\begin{array}{l}\text { Micro-porous } \\
\text { structures } \\
(1-4 \mu \mathrm{m})\end{array}$ & $\begin{array}{l}\text { Ti, anatase, and } \\
\text { rutile }\end{array}$ & $\begin{array}{l}0.77(\mathrm{Cu}) \\
0.62(\mathrm{Cu}) / 1.79(\mathrm{Zn}) \\
0.55(\mathrm{Cu}) / 2.53(\mathrm{Zn}) \\
0.39(\mathrm{Cu}) / 6.47(\mathrm{Zn}) \\
0.33(\mathrm{Cu}) / 8.92(\mathrm{Zn})\end{array}$ & $\begin{array}{l}\text { Day 20: } \\
4.5(\mathrm{Cu}) \\
3.2(\mathrm{Cu}) / 7.8(\mathrm{Zn}) \\
2.7(\mathrm{Cu}) / 23.2(\mathrm{Zn}) \\
2.3(\mathrm{Cu}) / 64.5(\mathrm{Zn}) \\
1.9(\mathrm{Cu}) / 94.9(\mathrm{Zn}) \\
\end{array}$ & [77] \\
\hline Ti6Al4V & 9 & $\begin{array}{l}\text { 3-9 g/L KOH, } \\
5-11 \mathrm{~g} / \mathrm{L} \text { phytic } \\
\text { acid, 2-10 g/L } \\
\text { EDTA-CuNa, } \\
\text { 2-10 g/L } \\
\text { EDTA-ZnNa }\end{array}$ & - & 11 & 3 & $\begin{array}{l}\text { Porous surface } \\
\text { with increasing } \\
\text { pore sizes for } \\
\text { increased levels of } \\
\text { Cu and/or Zn in } \\
\text { surface }\end{array}$ & $\mathrm{Ti}$, anatase & $\begin{array}{l}-/ 3.47(\mathrm{Zn}) \\
-/ 9.84(\mathrm{Zn}) \\
-/ 7.90(\mathrm{Zn}) \\
0.61(\mathrm{Cu}) / 11.41(\mathrm{Zn}) \\
0.98(\mathrm{Cu}) / 4.42(\mathrm{Zn}) \\
2.15(\mathrm{Cu}) / 5.42(\mathrm{Zn}) \\
-/ 5.64(\mathrm{Zn}) \\
1.25(\mathrm{Cu}) / 6.71(\mathrm{Zn}) \\
4.18(\mathrm{Cu}) / 2.89(\mathrm{Zn})\end{array}$ & - & [88] \\
\hline
\end{tabular}

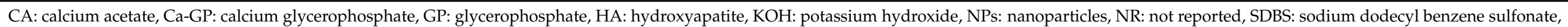

TCP: tricalcium phosphate, $\mathrm{ZnA}$ : zinc acetate. 


\subsection{Titanium Substrate}

Of the reviewed studies, most used commercially pure (CP) titanium $(62 \%)$, followed by Ti6Al4V (23\%), Ti6Al7Nb (4\%) [15,32], Ti40Nb [52], Ti29Nb13Ta4.6Zr [59], and Ti15Mo [86]. Titanium is used for bone implants because of its mechanical properties, corrosion resistance and chemical biocompatibility $[46,89]$. Ti6Al4V has a higher strength to weight ratio than $\mathrm{CP}$ titanium and is, therefore, the natural choice for load-bearing applications, such as joint replacing implants, while $\mathrm{CP}$ titanium is more frequently applied for non-load bearing applications, such as maxillofacial implants [90]. Clinical studies comparing the long-term outcomes of patients treated with either CP-Ti or Ti-alloys are lacking [91,92].

Ti6Al4V implants may release vanadium and aluminum ions that can induce cytotoxicity [93]. Other alloys employing niobium have, therefore, been developed, including Ti6Al7Nb and Ti40Nb, which have similar mechanical properties, but do not induce cytotoxicity [94]. In addition, the cytotoxic effects of $\mathrm{Al}$ and/or $\mathrm{V}$ can be mitigated by PEO, since it reduces the ion release of those species [89]. PEO is easily scalable and can be applied to human-sized implants [95]. In order to translate the results from in vitro studies, it is, therefore, interesting to investigate the antibacterial behavior of substrates that are designed and produced like an implant, for instance, through additive manufacturing. This also highlights one of the advantages of PEO, namely that it can be applied on highly porous surfaces [31].

\subsection{PEO Electrolyte}

The bioactivity of PEO-biofunctionalized implant surfaces is determined for a large part by the composition of the PEO electrolyte, as the elements in the electrolyte eventually make up the chemical composition of the implant surface. More than $50 \%$ of the studies included in this systematic review used electrolytes with $\mathrm{Ca}$ and $\mathrm{P}$ elements. The presence of $\mathrm{Ca}$ and $\mathrm{P}$ in the electrolyte can result in the formation of hydroxyapatite, which forms more than $60 \%$ of bone tissue and is associated with a $\mathrm{Ca} / \mathrm{P}$ ratio of $1.67[96,97]$. Calcium acetate and calcium glycerophosphate were the primary source of $\mathrm{Ca}$, while $\mathrm{CaCO}_{3}$ [52] and $\mathrm{C}_{12} \mathrm{H}_{22} \mathrm{CaO}_{14}$ [67] were also used in some studies. $\mathrm{P}$ is usually added in the form of calcium glycerophosphate, $\beta$-glycerophosphate, $\mathrm{H}_{3} \mathrm{PO}_{4}[52,69], \mathrm{K}_{4} \mathrm{P}_{2} \mathrm{O}_{7}$ [60], $\mathrm{NaH}_{2} \mathrm{PO}_{4}[48,49,65,71,74,75], \mathrm{NaPO}_{3}$ [67], or $\mathrm{Na}_{5} \mathrm{P}_{3} \mathrm{O}_{10}$ [85]. Another element used in about $30 \%$ of the included studies is $\mathrm{Na}$ in the form of $\mathrm{NaOH}, \mathrm{NaH}_{2} \mathrm{PO}_{4}[48,49,65,71,74,75]$, $\mathrm{NaPO}_{3}$ [67], $\mathrm{Na}_{5} \mathrm{P}_{3} \mathrm{O}_{10}$ [85], or $\mathrm{Na}_{2} \mathrm{SiO}_{3}[73,76,78,98]$. The addition of Na roughens the surface and enhances the $\mathrm{Ca} / \mathrm{P}$ ratio [99], which has been shown to enhance the osteogenic cell response $[100,101]$. In addition, the implantation of Na through plasma immersion has been found to stimulate the osteogenic differentiation of cells [102]. Moreover, $\mathrm{KOH}[60,70,88]$ is used as an alternative base for $\mathrm{NaOH}$ given its similar effects on osteogenic differentiation [103].

\subsection{PEO Processing Parameters}

The electrical parameters of the PEO process affect the surface morphology [42], including the porosity [104], pore size [105], pore shape [106], and pore density [107], as well as the surface chemistry $[83,84]$. Of the included studies, $54 \%$ controlled the voltage, $31 \%$ controlled the current density, and $13 \%$ controlled both, while 1 study did not report the PEO processing parameters. The oxidation times ranged between 0 and $180 \mathrm{~min}$, with $21 \%$ between 0-4 min, 50\% between 5-9 $\mathrm{min}, 19 \%$ between $10-14 \mathrm{~min}, 6 \%$ between $15-19 \mathrm{~min}$, and $4 \% \geq 20 \mathrm{~min}$. As the current density, voltage, or oxidation time increases, the spark discharge energy amplifies, affecting the mass of the oxide layer formed by a single pulse and resulting in enhanced growth of the oxide layer $[40,108]$. Furthermore, as temperature of the local discharge area increases, the plasma effect is enhanced, resulting in larger pore sizes and the transformation of amorphous $\mathrm{TiO}_{2}$ to anatase and rutile phases. Meanwhile, the intensity of the spark discharge enhances with time, meaning that prolonged oxidation times result in the formation of hydroxyapatite on the implant surface $[109,110]$. As such, 
PEO processing parameters largely affect the chemical and phase composition as well as the surface topography of the implant surface.

\subsection{Surface Morphology}

As PEO greatly affects the surface topography of titanium surfaces, all studies investigated the surface topography by scanning electron microscopy (SEM) and most studies reported a porous surface topography with rounded pores (Figure 4A). PEO transforms the native titanium oxide layer into a highly porous surface with interconnected porous networks, which is frequently described as a volcanic landscape with micropores that are $<10 \mu \mathrm{m}$ in diameter. In addition, flake-like morphologies $[35,55,63]$ and needle-like structures [58] are often observed. Furthermore, the thickness and porosity of the oxide layer were shown to depend on the composition of the PEO electrolyte and PEO processing parameters $[54,111]$. The specifications of the surface morphology in turn were shown to greatly influence the antibacterial behavior [112] and osteogenic properties $[113,114]$ of the implant surfaces.

A

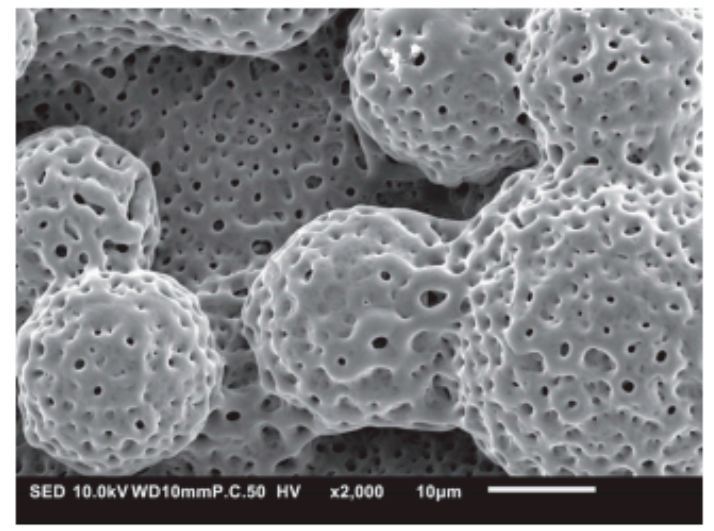

B

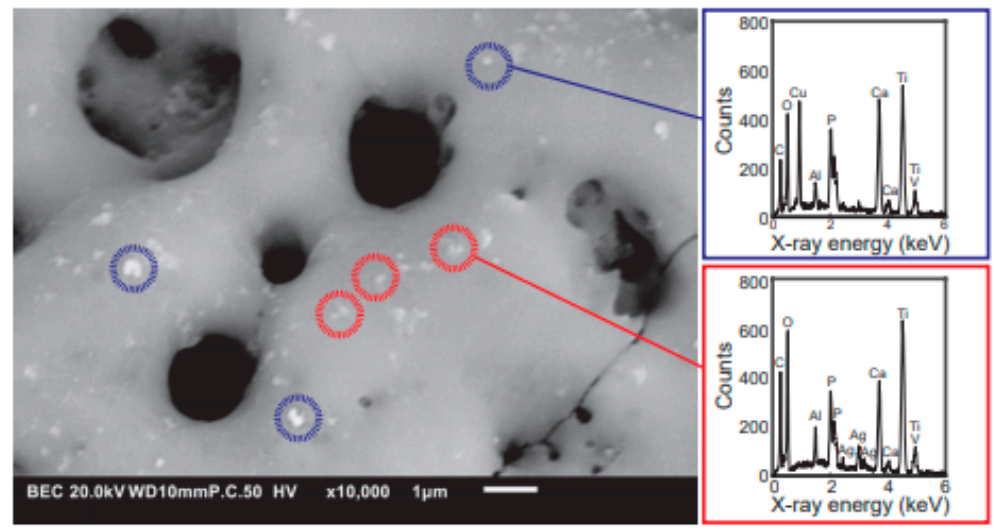

Figure 4. (A) SEM images of the typical surface morphology of titanium implants after PEO processing. (B) EDS analysis of the implant surface to characterize its chemical composition with spectrum of $\mathrm{Cu}$ (blue) and $\mathrm{Ag}$ (red) nanoparticles.

\subsection{Phase Composition by XRD}

One component of the surface that plays a major role in the biological behavior is the phase composition of the implants [115]. These phases can be analyzed with X-ray diffraction (XRD). Among the included studies, $87 \%$ analyzed the phase composition. Of those, all studies analyzed Ti phases and observed bare $\mathrm{Ti}(66 \%)$, anatase $(81 \%)$, and/or rutile $(66 \%)$. Some studies observed both Ti and anatase, but no studies reported solely Ti and rutile. This is in line with the observation that during PEO processing, first the metastable anatase is formed, which then turns into the stable rutile [116]. While all studies that performed XRD analysis identified the $\mathrm{TiO}_{2}$ phases, not all studies analyzed the other phases formed by the elements incorporated from the electrolyte. Since many PEO electrolytes contain both Ca and P, 19\% of the studies observed hydroxyapatite $[31,35,50,55-58,64,65]$ and $28 \%$ contain other $\mathrm{Ca} / \mathrm{P}$ phases including $\alpha$-TCP $[35,52,53], \beta$-TCP $[52,53], \mathrm{TiP}_{2} \mathrm{O}_{7}$ [70], $\mathrm{CaTiO}_{3}[31,55-58,65], \mathrm{Ca}_{2} \mathrm{P}_{2} \mathrm{O}_{7}$ [35,52], and $\mathrm{Ca}_{3}\left(\mathrm{PO}_{4}\right)_{2}$ [31,71]. In addition, phases with $\mathrm{Cu}, \mathrm{Cu}_{2} \mathrm{O}$, and $\mathrm{CuO}[76,78]$, as well as $\mathrm{ZnO}[78,79,87]$ were observed.

These phases were shown to affect the biological response. For instance, $\mathrm{TiO}_{2}$ is transformed from an amorphous phase into crystalline anatase and rutile phases that were shown to produce reactive oxygen species (ROS) [117], which in turn contribute to the desired antibacterial behavior [118]. 


\subsection{Content of the Antibacterial Elements Incorporated in the PEO Layers}

The antibacterial activity of $\mathrm{Ag}, \mathrm{Cu}$, and $\mathrm{Zn}$ may be present on the implant surface depending on the dose [119-121]. Therefore, it is important to quantify the content of these elements on the implant surface after PEO biofunctionalization. This analysis is usually done either by energy-dispersive X-ray spectroscopy (EDS; Figure 4B) or X-ray photoelectron spectroscopy (XPS). Among the included studies, 80\% reported the elemental composition of the surface, while $20 \%$ did not. The studies generally reported the elemental composition either in terms of atomic\% or weight $\%$ and found them to correlate with the amount of $\mathrm{Ag}, \mathrm{Cu}$, and $\mathrm{Zn}$ dispersed in the PEO electrolyte. The amount of $\mathrm{Ag}$ incorporated in the implant surfaces tended to be lower $(1.35 \pm 1.82 \mathrm{wt} \%)$ than $\mathrm{Cu}(7.70 \pm 10.17 \mathrm{wt} \%)$ and $\mathrm{Zn}(18.79 \pm 12.06 \mathrm{wt} \%)$, reflecting the lower minimal inhibitory concentration (MIC) of $\mathrm{Ag}(0.03-8 \mu \mathrm{g} / \mathrm{mL})$ as compared to $\mathrm{Cu}(256-448 \mu \mathrm{g} / \mathrm{mL})$ and $\mathrm{Zn}(765 \mu \mathrm{g} / \mathrm{mL})$ [122]. However, EDS does not exclusively measure the elemental composition of the surface but may penetrate deeper into the oxide layer. This is an important point, because it is not clear to what extent the species present deeper inside the oxide layer, which can be up to $10 \mu \mathrm{m}$ in thickness, and contribute to the antibacterial properties of biofunctionalized implants [15]. The amount of active agents present on the implant surface may not be directly related to the antibacterial activity, since the form in which the element is present on the surface (i.e., ionic species, nanocrystals, or nanoparticles) affects the antibacterial properties as well $[123,124]$.

\subsection{Ion Release}

An important antibacterial mechanism is through the release of metallic ions from the implant surface. These released ions do not only play a role in contact-killing, but also target planktonic bacteria in the implant surrounding, as this area could form a niche for bacteria [125]. Ion release was studied in $48 \%$ of the included studies and was measured from $12 \mathrm{~h}$ up to 56 days. Overall, the release of $\mathrm{Ag}, \mathrm{Cu}$, and $\mathrm{Zn}$ ions was found to be higher for the implant surfaces with a higher elemental content and a higher concentration of the active agents in the PEO electrolyte. The combination of $\mathrm{Ag}$ with $\mathrm{Cu}$ or $\mathrm{Zn} \mathrm{NPs}$ on the implant surface resulted in enhanced $\mathrm{Cu}$ or $\mathrm{Zn}$ release while the Ag release was reduced in the first $24 \mathrm{~h}[19,20]$. Similarly, higher concentrations of zinc acetate added to copper acetate resulted in enhanced $\mathrm{Zn}$ ion release while $\mathrm{Cu}$ ion release was reduced with higher concentrations of zinc acetate [77]. This may stem from galvanic coupling favoring the oxidation and release of one element over the other [126,127]. When studied in detail, this may allow for controlled release profiles and accompanying antibacterial effects.

Ion release results depend on the liquid in which these measurements are performed. Frequently used liquids are phosphate-buffered saline (PBS) and simulated body fluid (SBF) [128]. Ion release does not only depend on the surface content, but also on the form in which the antibacterial agent is present on the surface (i.e., as ionic species, nanoparticles, or other forms) [124]. Ideally, one could control the release of ions to not only prevent infection immediately after surgery, but also ward off late implant-associated infections [129]. However, comparing the reported ions release kinetics is difficult due to the different units, specimen designs, and measurement setups being used. In addition to the previously mentioned parameters, the surface area plays an important role in determining the concentration of the released ions, as a larger area allows for more agents to be incorporated on the surface, in turn leading to a higher release rate [31]. The reported concentrations of release ions should, therefore, be normalized with respect to the surface area of the specimens to enable direct comparison between different studies. The information regarding the surface area is generally not reported in the studies, rendering a direct comparison impossible.

\section{Antibacterial Properties}

Surface biofunctionalization by $\mathrm{PEO}$ with $\mathrm{Ag}, \mathrm{Cu}$, and $\mathrm{Zn}$ results in antibacterial surfaces. In the following section, we will first compare the antibacterial activity of PEO biofunctionalized titanium implants bearing $\mathrm{Ag}, \mathrm{Cu}$, and $\mathrm{Zn}$ found by in vitro and ex 
vivo studies (Table 5). Then, we will discuss the factors that determine the antibacterial activity. First of all, the types of the bacterial species and strains were shown to affect the susceptibility and resistance of bacteria to antibacterial agents [130], their ability to infect host cells [131], and their pathogenicity [132]. Moreover, the type of assay, the inoculation dose, and the culture time used in the studies may affect the observed antibacterial activity. Finally, the activity against adherent and/or planktonic bacteria is discussed, as the adherence of bacteria may initiate biofilm formation, while planktonic bacteria form a source for reinfection and host cell invasion [133]. 
Table 5. Antibacterial tests and results on PEO-modified Ti-surfaces bearing single or multiple elements.

\begin{tabular}{|c|c|c|c|c|c|c|c|c|}
\hline Bacterial Species & Bacterial Strain & Source & Analysis Method & Duration (h) & $\begin{array}{c}\text { Test } \\
\text { Inoculum }\end{array}$ & $\begin{array}{l}\text { Planktonic/ } \\
\text { Adherent }\end{array}$ & Main Outcomes & Ref \\
\hline \multicolumn{9}{|c|}{$\mathrm{Ag}$} \\
\hline MRSA & AMC201 & Ag NPs & $\begin{array}{l}\text { Modified version of } \\
\text { JIS Z 2801:2000 }\end{array}$ & 24 & $10^{7} \mathrm{CFU} / \mathrm{mL}$ & Adherent & $\begin{array}{l}\text { After } 24 \mathrm{~h}: 98 \text { and } 99.75 \% \text { reduction by } \\
\text { incorporation of } 0.3 \text { and } 3 \mathrm{~g} / \mathrm{L} \mathrm{Ag} \mathrm{NPs}\end{array}$ & [15] \\
\hline MRSA & AMC201 & Ag NPs & $\begin{array}{l}\text { Petrifilm }{ }^{\mathrm{TM}} \text { assay } \\
\text { Zone of inhibition } \\
\text { CFU count } \\
\text { SEM } \\
\text { Ex vivo }\end{array}$ & 48 & $10^{3}-10^{8} \mathrm{CFU} / \mathrm{mL}$ & Adherent & $\begin{array}{l}\text { Significantly reduced numbers of viable } \\
\text { bacterial colonies by incorporation of } \\
\mathrm{Ag} N \mathrm{~N} \text { in the surface after } 15 \mathrm{~min} \text {. } \\
\text { Four-logs reduction in the numbers of } \\
\text { viable bacterial colonies in the ex vivo } \\
\text { infection model by incorporation of } \mathrm{Ag} \text {, } \\
\text { compared with a 2-logs reduction in } \\
\text { absence of Ag after } 24 \mathrm{~h} \text {. } \\
\text { Prevention biofilm formation for at } \\
\text { least } 48 \mathrm{~h}\end{array}$ & {$[31]$} \\
\hline MRSA & AMC201 & Ag NPs & $\begin{array}{l}\text { Modified version of } \\
\text { JIS Z 2801:2000 }\end{array}$ & 24 & $10^{7} \mathrm{CFU} / \mathrm{mL}$ & Adherent & $\begin{array}{l}100 \% \text { killed by incorporation of } \\
0.03 \mathrm{wt} \% \mathrm{Ag} \text { at } 24 \mathrm{~h}\end{array}$ & [32] \\
\hline $\begin{array}{l}\text { S. aureus } \\
\text { E. coli }\end{array}$ & $\begin{array}{l}\text { ATCC6538 } \\
\text { ATCC25922 }\end{array}$ & $\mathrm{AgNO}_{3}$ & Spread plate analysis & 24 & $1.6 \cdot 10^{5} \mathrm{CFU} / \mathrm{mL}$ & Planktonic & $\begin{array}{l}\text { After } 24 \mathrm{~h}:>99.8 \text { reduction by } \\
\text { incorporation of }>0.1 \mathrm{wt} \% \mathrm{Ag}, \\
\text { compared with a reduction of } 20 \% \text { in } \\
\text { absence of } \mathrm{Ag}\end{array}$ & [35] \\
\hline E. coli & ATCC25933 & $\mathrm{AgNO}_{3}$ & Spread plate analysis & 12 & $10^{6} \mathrm{CFU} / \mathrm{mL}$ & Adherent & After 12 h: $>99.9 \%$ eradication of $E$. coli & [48] \\
\hline $\begin{array}{l}\text { S. aureus } \\
\text { E. coli }\end{array}$ & $\begin{array}{l}\text { ATCC6538 } \\
\text { ATCC25922 }\end{array}$ & Ag NPs & $\begin{array}{l}\text { CFU count } \\
\text { Fluorescence } \\
\text { measurement }\end{array}$ & 24 & $0.0001 \mathrm{OD}_{590}$ & Adherent & $\begin{array}{l}\text { After } 24 \mathrm{~h} \text { : complete eradication for } E \text {. } \\
\text { coli and 6-log reduction for S.aureus } \\
\text { with } 5.8 \text { at } \% \mathrm{Ag} \\
\text { Stronger antibacterial effect on } E . \text { coli } \\
\text { compared to S. aureus }\end{array}$ & [49] \\
\hline MRSA & USA300 & Ag NPs & $\begin{array}{l}\text { Zone of inhibition } \\
\text { CFU count } \\
\text { SEM } \\
\text { Ex vivo }\end{array}$ & 48 & $10^{4}-10^{7} \mathrm{CFU} / \mathrm{mL}$ & $\begin{array}{l}\text { Adherent } \\
\text { Planktonic }\end{array}$ & $\begin{array}{l}\text { After } 24 \mathrm{~h} \text { : enhanced zone of inhibition } \\
\text { for PT-AgSr samples compared to } \\
\text { PT-Ag samples. } \\
\text { Complete eradiation of adherent and } \\
\text { planktonic bacteria in vitro and ex vivo. } \\
\text { After } 48 \text { h: prevention of biofilm } \\
\text { formation in Ag-containing surfaces. }\end{array}$ & {$[50]$} \\
\hline $\begin{array}{l}\text { S.aureus } \\
\text { E.coli }\end{array}$ & $\begin{array}{l}\text { NBRC122135 } \\
\text { NBRC3972 }\end{array}$ & $\mathrm{AgNO}_{3}$ & ISO 22196:2007 & 24 & $0.4-3.0 \cdot 10^{6} \mathrm{CFU} / \mathrm{mL}$ & Adherent & $\begin{array}{l}\text { After } 24 \mathrm{~h}:>0.05 \mathrm{mM} \mathrm{Ag} \text { in } \mathrm{PEO} \\
\text { electrolyte reduced bacteria }>90 \% \text {. } \\
\text { Inhibitory effect was stronger for } E \text {. coli } \\
\text { compared to } S \text {. aureus }\end{array}$ & {$[51]$} \\
\hline
\end{tabular}


Table 5. Cont.

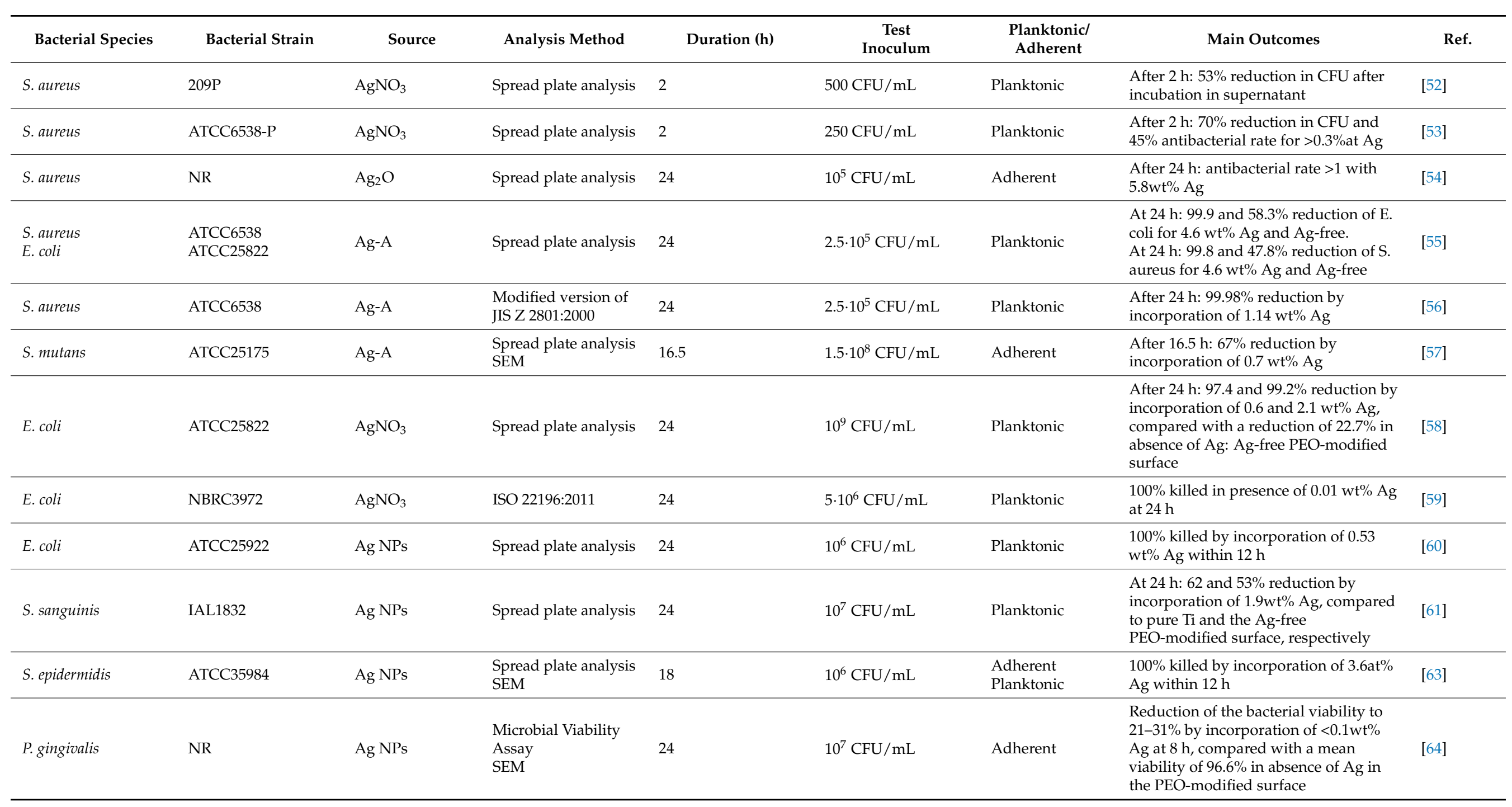


Table 5. Cont.

\begin{tabular}{|c|c|c|c|c|c|c|c|c|}
\hline Bacterial Species & Bacterial Strain & Source & Analysis Method & Duration (h) & $\begin{array}{c}\text { Test } \\
\text { Inoculum }\end{array}$ & $\begin{array}{l}\text { Planktonic/ } \\
\text { Adherent }\end{array}$ & Main Outcomes & Ref. \\
\hline $\begin{array}{l}\text { E. coli } \\
\text { S. aureus } \\
\text { MRSA }\end{array}$ & $\begin{array}{l}\text { ATCC25922 } \\
\text { ATCC6538 } \\
\text { Mu50 }\end{array}$ & Ag-A & $\begin{array}{l}\text { CFU count } \\
\text { SEM }\end{array}$ & 24 & $0.0005 \mathrm{OD}_{590}$ & Adherent & $\begin{array}{l}\text { 4-6 log inhibition of E. coli, 3-5 log } \\
\text { inhibition of S. aureus, and } 2-5 \log \\
\text { inhibition of MRSA after } 24 \mathrm{~h} \text { for } 0.1 \\
\text { and } 0.5 \text { and } 0.8 \mathrm{~g} / \mathrm{L} \text { Ag respectively }\end{array}$ & [65] \\
\hline S. aureus & В 918 & Ag NPs & Spread plate analysis & 24 & $10^{6} \mathrm{CFU} / \mathrm{mL}$ & Adherent & $\begin{array}{l}\text { Lower amounts of adherent bacteria } \\
\text { after } 2 \mathrm{~h} \text {. } \\
\text { No inhibition at later time points }\end{array}$ & [66] \\
\hline S. aureus & NR & $\mathrm{Cu}(\mathrm{OAc})_{2}$ & Spread plate analysis & 4 & $10^{6} \mathrm{CFU} / \mathrm{mL}$ & Planktonic & $\begin{array}{l}\text { Significantly reduced numbers of } \\
\text { bacterial colonies by incorporation of } \\
1.4 \mathrm{wt} \% \mathrm{Cu} \text { in the surface after } 4 \mathrm{~h}\end{array}$ & [36] \\
\hline S. aureus & $209 \mathrm{P}$ & $\begin{array}{l}\text { Cu-substituted } \\
\text { HA }\end{array}$ & Spread plate analysis & 2 & $500 \mathrm{CFU} / \mathrm{mL}$ & Planktonic & $\begin{array}{l}\text { After } 2 \mathrm{~h}: 27 \% \text { reduction in optical } \\
\text { density after incubation in supernatant }\end{array}$ & [52] \\
\hline S. aureus & NR & $\mathrm{C}_{12} \mathrm{H}_{22}-\mathrm{CuO}_{14}$ & $\begin{array}{l}\text { Spread plate analysis } \\
\text { SEM }\end{array}$ & 24 & $10^{4} \mathrm{CFU} / \mathrm{mL}$ & Adherent & $\begin{array}{l}\text { After } 24 \mathrm{~h}: 100 \% \text { antibacterial rate on } \\
\text { Cu surfaces } \\
\text { Morphological changes and disrupted } \\
\text { membrane of bacterial cells. }\end{array}$ & [67] \\
\hline E. coli & ATCC25922 & $\mathrm{Cu}\left(\mathrm{NO}_{3}\right)_{2} \cdot \mathrm{H}_{2} \mathrm{O}$ & $\begin{array}{l}\text { Zone of inhibition } \\
\text { Adhesion test }\end{array}$ & 24 & $10^{8} \mathrm{CFU} / \mathrm{mL}$ & $\begin{array}{l}\text { Adherent } \\
\text { Planktonic }\end{array}$ & $\begin{array}{l}\text { After } 24 \mathrm{~h} \text { : zone of inhibition around } \\
0.54-0.72 \mathrm{wt} \% \mathrm{Cu} \text {. } \\
\text { No bacterial cells adhering after } 24 \mathrm{~h}\end{array}$ & [69] \\
\hline $\begin{array}{l}\text { S. aureus } \\
\text { E. Coli }\end{array}$ & $\begin{array}{l}\text { ATCC43300 } \\
\text { ATCC25922 }\end{array}$ & EDTA-CuNA $_{2}$ & Spread plate analysis & 24 & $5 \cdot 10^{5} \mathrm{CFU} / \mathrm{mL}$ & Adherent & $\begin{array}{l}\text { After } 24 \text { h: complete eradication of } S \text {. } \\
\text { aureus and E. coli for } 1.92 \mathrm{wt} \% \mathrm{Cu} \text {. } \\
\text { After } 14 \text { days no antibacterial activity. }\end{array}$ & [70] \\
\hline S. aureus & ATCC6538 & $\begin{array}{l}\mathrm{CuA} \\
\text { monohydrate }\end{array}$ & Spread plate analysis & 24 & $10^{5} \mathrm{CFU} / \mathrm{mL}$ & Adherent & $\begin{array}{l}\text { After } 24 \mathrm{~h}:>99 \% \text { growth reduction with } \\
5.05 \mathrm{at} \% \mathrm{Cu} \text { in the surface. }\end{array}$ & [71] \\
\hline
\end{tabular}


Table 5. Cont.

\begin{tabular}{|c|c|c|c|c|c|c|c|c|}
\hline Bacterial Species & Bacterial Strain & Source & Analysis Method & Duration (h) & $\begin{array}{c}\text { Test } \\
\text { Inoculum }\end{array}$ & $\begin{array}{c}\text { Planktonic/ } \\
\text { Adherent }\end{array}$ & Main Outcomes & Ref \\
\hline S. aureus & ATCC25923 & $\mathrm{Cu}(\mathrm{OAc})_{2}$ & $\begin{array}{l}\text { Spread plate analysis } \\
\text { Live/dead staining } \\
\text { SEM }\end{array}$ & 96 & $10^{5} \mathrm{CFU} / \mathrm{mL}$ & $\begin{array}{l}\text { Adherent } \\
\text { Planktonic }\end{array}$ & $\begin{array}{l}\text { At } 6 \text { h: } 0.6 \times 10^{5} \mathrm{CFU} / \mathrm{cm}^{2} \text { on } 1.93 \mathrm{wt} \% \\
\text { Cu-PEO and } 1.5 \times 10^{5} \mathrm{CFU} / \mathrm{cm}^{2} \text { on } \\
\text { Cu-free. } \\
\text { At } 24 \mathrm{~h}: 0.6 \times 10^{5} \mathrm{CFU} / \mathrm{cm}^{2} \text { on } 1.93 \\
\text { wt } \% \mathrm{Cu} \text {-PEO and } 9.7 \times 10^{5} \mathrm{CFU} / \mathrm{cm}^{2} \\
\text { on Cu-free. } \\
\text { At } 6 \text { h: } 1.0 \times 10^{5} \mathrm{CFU} / \mathrm{mL} \text { for } 1.93 \mathrm{wt} \% \\
\mathrm{Cu} \text { - PEO and } 3.8 \times 10^{5} \mathrm{CFU} / \mathrm{mL} \text { on } \\
\mathrm{Cu} \text {-free. } \\
\text { At } 24 \mathrm{~h}: 5.2 \times 10^{5} \mathrm{CFU} / \mathrm{mL} \text { for } 1.93 \\
\text { wt } \% \text { Cu-PEO and } 200 \times 10^{5} \mathrm{CFU} / \mathrm{mL} \\
\text { on Cu-free. }\end{array}$ & [72] \\
\hline S. aureus & NR & $\mathrm{CuSO}_{4}$ & $\begin{array}{l}\text { Macrophage } \\
\text { bactericidal assay } \\
\text { SEM }\end{array}$ & 2 & $10^{7} \mathrm{CFU} / \mathrm{mL}$ & Planktonic & $\begin{array}{l}\text { Significantly enhanced } \\
\text { macrophage-bactericidal capacity on } 2 \\
\text { mM Cu-incorporated PEO-modified } \\
\text { surface }\end{array}$ & [73] \\
\hline $\begin{array}{l}\text { S. aureus } \\
\text { E. coli }\end{array}$ & NR & $\mathrm{Cu}$ NPs & Live/dead staining & 24 & $10^{5} \mathrm{CFU} / \mathrm{mL}$ & Adherent & Majority of bacteria killed after $24 \mathrm{~h}$ & [74] \\
\hline E. coli & CMCC44102 & $\mathrm{Cu}_{2} \mathrm{O} \mathrm{NPs}$ & ASTM G21-13 & 24 & NR & Adherent & $\begin{array}{l}\text { At } 24 \mathrm{~h}: 99.74 \% \text { killed by incorporation } \\
\text { of } 10 \mathrm{~g} \cdot \mathrm{L}-1 \mathrm{Cu}_{2} \mathrm{O} \text { NPs, compared to } \\
95.25 \% \text { killed in absence of } \mathrm{Cu} \text { in the } \\
\text { PEO-modified surface }\end{array}$ & {$[76]$} \\
\hline \multicolumn{9}{|c|}{$\mathrm{Zn}$} \\
\hline $\begin{array}{l}\text { S. aureus } \\
\text { E. coli }\end{array}$ & $\begin{array}{l}\text { ATCC25923 } \\
\text { ATCC25922 }\end{array}$ & $\mathrm{ZnO} N P s$ & ASTM G21-1996 & 24 & $10^{6} \mathrm{CFU} / \mathrm{mL}$ & Planktonic & $\begin{array}{l}\text { After } 24 \text { h: reduced numbers of viable } \\
\text { colonies by incorporation of } Z n \\
\text { compared with } Z n \text {-free surfaces }\end{array}$ & [37] \\
\hline S. aureus & $209 \mathrm{P}$ & $\begin{array}{l}\text { Zn-substituted } \\
\text { HA }\end{array}$ & Spread plate analysis & 2 & $500 \mathrm{CFU} / \mathrm{mL}$ & Planktonic & $\begin{array}{l}\text { After } 2 \mathrm{~h}: 40 \% \text { reduction in optical } \\
\text { density after incubation in supernatant }\end{array}$ & [52] \\
\hline E. coli & NR & $\begin{array}{l}\text { ZnO NPs } \\
\text { Zn-EDTA }\end{array}$ & $\begin{array}{l}\text { Measurement of } \\
\mathrm{OD}_{600}\end{array}$ & 24 & NR & Planktonic & $\begin{array}{l}\text { After } 24 \mathrm{~h}: 50 \% \text { reduction in } \mathrm{OD}_{600} \\
\text { values of culture medium }\end{array}$ & [79] \\
\hline E. coli & NBRC3972 & $\mathrm{ZnCl}_{2}$ & Spread plate analysis & 24 & $4.9 \cdot 10^{6} \mathrm{CFU} / \mathrm{mL}$ & Adherent & After $24 \mathrm{~h}$ : less than 1 log reduction & [80] \\
\hline
\end{tabular}


Table 5. Cont.

\begin{tabular}{|c|c|c|c|c|c|c|c|c|}
\hline Bacterial Species & Bacterial Strain & Source & Analysis Method & Duration (h) & $\begin{array}{c}\text { Test } \\
\text { Inoculum }\end{array}$ & $\begin{array}{l}\text { Planktonic/ } \\
\text { Adherent }\end{array}$ & Main Outcomes & Ref. \\
\hline $\begin{array}{l}\text { S. aureus } \\
\text { E. coli }\end{array}$ & $\begin{array}{l}\text { ATCC25923 } \\
\text { ATCC25922 }\end{array}$ & $\mathrm{ZnA}$ & $\begin{array}{l}\text { Spread plate analysis } \\
\text { SEM }\end{array}$ & 24 & $10^{7} \mathrm{CFU} / \mathrm{mL}$ & Planktonic & $\begin{array}{l}\text { After } 24 \mathrm{~h}: 40 \% \text { enhanced antibacterial } \\
\text { rate on E.coli. } \\
\text { No effect on S. aureus }\end{array}$ & [81] \\
\hline $\begin{array}{l}\text { S. aureus } \\
\text { P. aeruginosa }\end{array}$ & NR & $\mathrm{ZnA}$ & $\begin{array}{l}\text { Live/dead staining } \\
\text { SEM }\end{array}$ & 24 & $\mathrm{OD}_{600} \sim 0.35$ & Adherent & $\begin{array}{l}\text { Significantly reduced numbers of viable } \\
\text { colonies by incorporation of } 9.7 \mathrm{at} \% \mathrm{Zn} \\
\text { at } 6 \text { and } 24 \mathrm{~h}\end{array}$ & [82] \\
\hline $\begin{array}{l}\text { S. aureus } \\
\text { E. coli }\end{array}$ & $\begin{array}{l}\text { ATCC25923 } \\
\text { ATCC25922 }\end{array}$ & $\mathrm{ZnA}$ & $\begin{array}{l}\text { Spread plate analysis } \\
\text { SEM }\end{array}$ & 24 & $10^{7} \mathrm{CFU} / \mathrm{mL}$ & Adherent & $\begin{array}{l}\text { At } 24 \mathrm{~h}: 40.2,99.2 \text { and } 100 \% \text { reduction } \\
\text { of } E \text {. coli for } 4.6,7.1 \text {, and } 9.3 \mathrm{wt} \% \mathrm{Zn} \text {. } \\
\text { At } 24 \mathrm{~h} \text { : } 96.3,99.5 \text {, and } 99.8 \% \text { reduction } \\
\text { of S. aureus for } 4.6,7.1 \text {, and } 9.3 \mathrm{wt} \% \mathrm{Zn}\end{array}$ & [83] \\
\hline $\begin{array}{l}\text { S. aureus } \\
\text { E. coli }\end{array}$ & NR & $\mathrm{ZnA}$ & $\begin{array}{l}\text { Spread plate analysis } \\
\text { Live/dead staining } \\
\text { SEM }\end{array}$ & 24 & $10^{5} \mathrm{CFU} / \mathrm{mL}$ & $\begin{array}{l}\text { Adherent } \\
\text { Planktonic }\end{array}$ & $>90 \%$ killed at $24 \mathrm{~h}$ & {$[84]$} \\
\hline S. mutans & ATCC 25175 & $\mathrm{ZnA}$ & $\begin{array}{l}\text { Spread plate analysis } \\
\text { SEM }\end{array}$ & 48 & $10^{9} \mathrm{CFU} / \mathrm{mL}$ & Adherent & $\begin{array}{l}\text { At } 24 \mathrm{~h}: 62.54,69.84 \text { and } 79.19 \% \\
\text { reduction for } 0.199,0.574 \text { and } 1.995 a t \% \\
\text { Zn }\end{array}$ & [85] \\
\hline $\begin{array}{l}\text { S. aureus } \\
\text { MRSA } \\
\text { S. epidermidis }\end{array}$ & $\begin{array}{l}\text { ATCC } 25923 \\
\text { MRSA1030 } \\
\text { ATCC700296 } \\
\text { S. epidermidis } 15560\end{array}$ & $\begin{array}{l}\mathrm{ZnO} \text { and } \\
\mathrm{Zn}_{3}\left(\mathrm{PO}_{4}\right)_{2} \\
\text { particles }\end{array}$ & Spread plate analysis & 4 & $10^{6} \mathrm{CFU} / \mathrm{mL}$ & Adherent & $\begin{array}{l}\text { After } 4 \text { h: no growth inhibition for } S \text {. } \\
\text { aureus and MRSA, and } 90 \% \text { eradication } \\
\text { of S. epidermidis on Zn-bearing surfaces. }\end{array}$ & [86] \\
\hline \multicolumn{9}{|c|}{$\mathrm{Ag}$ and $\mathrm{Cu}$} \\
\hline MRSA & USA300 & $\mathrm{Ag}$ and $\mathrm{Cu}$ NPs & $\begin{array}{l}\text { Zone of inhibition } \\
\text { CFU count } \\
\text { SEM } \\
\text { Ex vivo }\end{array}$ & 24 & $10^{4}-10^{7} \mathrm{CFU} / \mathrm{mL}$ & $\begin{array}{l}\text { Adherent } \\
\text { Planktonic }\end{array}$ & $\begin{array}{l}\text { After } 24 \mathrm{~h} \text { : zone of inhibition and } \\
\text { eradication of adhering and planktonic } \\
\text { bacteria in vitro and ex vivo for surface } \\
\text { containing }>50 \% \mathrm{Ag} \text { and Cu NPs. } \\
\text { No antibacterial properties for solely } \\
\mathrm{Cu} \text { NP-bearing surfaces and controls. }\end{array}$ & [19] \\
\hline \multicolumn{9}{|c|}{$\mathrm{Ag}$ and $\mathrm{Zn}$} \\
\hline MRSA & USA300 & $\mathrm{Ag}$ and $\mathrm{Zn} \mathrm{NPs}$ & $\begin{array}{l}\text { Zone of inhibition } \\
\text { CFU count } \\
\text { SEM } \\
\text { Ex vivo }\end{array}$ & 24 & $10^{4}-10^{7} \mathrm{CFU} / \mathrm{mL}$ & $\begin{array}{l}\text { Adherent } \\
\text { Planktonic }\end{array}$ & $\begin{array}{l}\text { After } 24 \mathrm{~h} \text { : zone of inhibition and } \\
\text { eradication of adhering and planktonic } \\
\text { bacteria in vitro and ex vivo for surface } \\
\text { containing }>50 \% \text { Ag and Zn NPs. } \\
\text { No antibacterial properties for solely Zn } \\
\text { NP bearing surfaces and controls. }\end{array}$ & [20] \\
\hline
\end{tabular}


Table 5. Cont.

\begin{tabular}{|c|c|c|c|c|c|c|c|c|}
\hline Bacterial Species & Bacterial Strain & Source & Analysis Method & Duration (h) & $\begin{array}{c}\text { Test } \\
\text { Inoculum }\end{array}$ & $\begin{array}{l}\text { Planktonic/ } \\
\text { Adherent }\end{array}$ & Main Outcomes & Ref. \\
\hline S. aureus & ATCC25923 & $\begin{array}{l}\mathrm{Ag} \text { NPs and } \\
\mathrm{ZnA}\end{array}$ & $\begin{array}{l}\text { Spread plate analysis } \\
\text { SEM }\end{array}$ & 24 & $10^{5} \mathrm{CFU} / \mathrm{mL}$ & $\begin{array}{l}\text { Adherent } \\
\text { Planktonic }\end{array}$ & $\begin{array}{l}\text { At } 24 \mathrm{~h}: 4.1,2.5 \text {, and } 2.4 \cdot 10^{3} \mathrm{CFU} / \mathrm{cm}^{2} \\
\text { on } \mathrm{Ag} \text { and } \mathrm{Zn} \text { co-doped surfaces } \\
\text { compared with } 2.3 \cdot 10^{6} \mathrm{CFU} / \mathrm{cm}^{2} \text { on } \\
\text { polished } \mathrm{Ti} \text {, respectively. } \\
\text { Significantly reduced numbers of viable } \\
\text { colonies by incorporation of } \mathrm{Ag} \mathrm{NPs} \\
\text { and } \mathrm{Zn} \text { compared to polished Ti. }\end{array}$ & [87] \\
\hline
\end{tabular}

\begin{tabular}{|c|c|c|c|c|c|c|c|c|}
\hline S. aureus & ATCC25923 & $\begin{array}{l}\mathrm{Cu}(\mathrm{OAc})_{2} \\
\mathrm{ZnA}\end{array}$ & $\begin{array}{l}\text { Spread plate analysis } \\
\text { Live/dead staining } \\
\text { SEM }\end{array}$ & 24 & $10^{5} \mathrm{CFU} / \mathrm{mL}$ & $\begin{array}{l}\text { Adherent } \\
\text { Planktonic }\end{array}$ & $\begin{array}{l}\text { At } 6 \mathrm{~h}: 2.63,1.47 \text {, and } 0.84 \cdot 10^{5} \\
\mathrm{CFU} / \mathrm{cm}^{2} \text { on } \mathrm{Cu} \text { and } \mathrm{Zn} \text { co-doped } \\
\text { surfaces compared with } 1.8 \text {, and } 8.5 \cdot 10^{5} \\
\mathrm{CFU} / \mathrm{cm}-2 \text { on } \mathrm{Cu} \text {-single doped and } \\
\mathrm{Cu} \text {-free surfaces, respectively. } \\
\mathrm{At} 24 \mathrm{~h}: 3.72,2.89 \text {, and } 1.32 \cdot 10^{5} \\
\mathrm{CFU} / \mathrm{cm}^{2} \text { on } \mathrm{Cu} \text { and } \mathrm{Zn} \text { co-doped } \\
\text { surfaces compared to } 2.89 \text { and } 16 \cdot 10^{5} \\
\mathrm{CFU} / \mathrm{cm}^{2} \text { on Cu-single doped and } \\
\mathrm{Cu} \text {-free surfaces, respectively. } \\
\text { Significantly reduced number of viable } \\
\text { colonies by incorporation of }>2.53 \mathrm{wt} \% \\
\mathrm{Zn} \text { and }<0.55 \mathrm{wt} \% \mathrm{Cu} \text {, compared to } 0.77 \\
\mathrm{wt} \% \mathrm{Cu}\end{array}$ & {$[77]$} \\
\hline E. coli & CMCC44102 & $\begin{array}{l}\mathrm{Cu}_{2} \mathrm{O} \text { and } \mathrm{ZnO} \\
\mathrm{NPs}\end{array}$ & ASTM G21-13 & 24 & $10^{6} \mathrm{CFU} / \mathrm{mL}$ & Planktonic & $\begin{array}{l}\text { PEO-modified surfaces bearing } \mathrm{Cu}_{2} \mathrm{O} \\
\text { NPs demonstrated a superior } \\
\text { antibacterial activity } 100 \% \text { killed, } \\
\text { compared with PEO-modified surfaces } \\
\text { bearing } \mathrm{ZnO} \text { NPs }\end{array}$ & {$[78]$} \\
\hline $\begin{array}{l}\text { MRSA } \\
\text { S. aureus } \\
\text { E. coli }\end{array}$ & $\begin{array}{l}\text { ATCC } 43300 \\
\text { CGMCC } 12465 \\
\text { CGMCC } 13373\end{array}$ & $\begin{array}{l}\text { EDTA-CuNa } \\
\text { EDTA-ZnNa }\end{array}$ & Spread plate analysis & 24 & $10^{6} \mathrm{CFU} / \mathrm{mL}$ & Adherent & $\begin{array}{l}\text { After } 24 \text { h: complete prevention of } \\
\text { growth with }>6 \mathrm{~g} / \mathrm{L} \text { Cu or } \mathrm{Zn} \text { in PEO } \\
\text { electrolyte against MRSA, S. aureus and } \\
\text { E. coli. }\end{array}$ & {$[88]$} \\
\hline
\end{tabular}

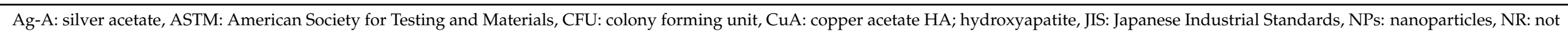
reported, SEM: scanning electron microscopy, ZnA: zinc acetate. 


\subsection{Comparing Antibacterial Activities of $\mathrm{Ag}, \mathrm{Cu}$, and $\mathrm{Zn}$}

All the included studies reported antibacterial activity. Guidelines designate a material as antibacterial when it induces a $>99.9 \%$ (i.e., $3-\log$ ) reduction in the number of viable bacteria [134]. However, this is a guideline for treatment, while the required reduction in the bacterial load for the prevention of IAI is not known. In fact, $48 \%$ of the studies using $\mathrm{Ag}, 14 \%$ of the studies with $\mathrm{Cu}, 10 \%$ of the studies with $\mathrm{Zn}$, and $80 \%$ of the studies that combined these metallic agents reduced the bacterial load by $>99.9 \%$. This indicates that surfaces biofunctionalized with $\mathrm{Ag}$ demonstrate the highest degree of antibacterial activity, while $\mathrm{Cu}$ and $\mathrm{Zn}$ were less effective, which is not surprising given the much lower MIC for $\mathrm{Ag}$ as compared to $\mathrm{Cu}$ and $\mathrm{Zn}$ [122]. Interestingly, combining $\mathrm{Ag}, \mathrm{Cu}$, and $\mathrm{Zn}$ resulted in much higher levels of antibacterial activity, while the doses of single elements can be reduced $[19,20,87,88]$.

Studies that focused on the antibacterial mechanisms of $\mathrm{Ag}, \mathrm{Cu}$, and $\mathrm{Zn}$ NPs suggest that two antibacterial mechanisms play a role: ion release killing [135] and the generation of reactive oxygen species (ROS) [136]. Ions released from the implant diffuse across the bacterial cell wall and penetrate into bacteria where vital bacterial structures are targeted. Meanwhile, ROS are highly reactive and cause lysis of the bacterial cell wall. It was found that $\mathrm{Cu}$ showed the best antibacterial activity as a result of contact killing [137], while Ag exhibited most of its antibacterial activity through both ion release and contact killing [138]. Furthermore, the synergistic antibacterial properties of AgNPs and Zn ions were observed to stem from long-range $\mathrm{Zn}$ ion release and contact-killing effects from Ag through microgalvanic coupling $[29,139]$.

We plotted a 3D graph showing the correlation between antibacterial activity, cytocompatibility, and surface content of the antibacterial agent for the titanium substrates biofunctionalized by PEO with Ag, Cu, or Zn (Figure 5). Very few studies reported all of these 3 parameters. This analysis shows that $\mathrm{Ag}$ indeed resulted in the highest levels of antibacterial activity at lower doses compared to $\mathrm{Cu}$ and $\mathrm{Zn}$, yet also induced cytotoxicity more frequently. However, a direct comparison between the included studies, and thereby of $\mathrm{Ag}, \mathrm{Cu}$, and $\mathrm{Zn}$ bearing surfaces, was hampered by a large number of variables that differ in the various studies and are addressed in the next paragraphs of this section.
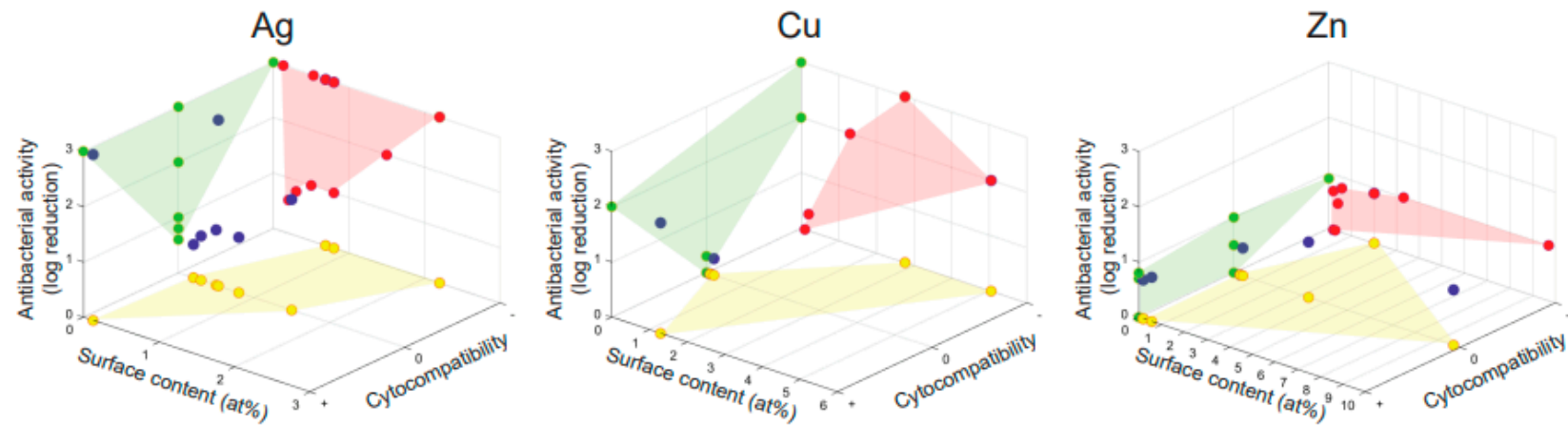

Figure 5. The relation between the antibacterial activity, cytocompatibility, and surface content for titanium surfaces biofunctionalized by PEO with $\mathrm{Ag}, \mathrm{Cu}$, or $\mathrm{Zn}$. The reported antibacterial activity as a function of surface content and cytocompatibility is depicted by the blue dots. The green, red, and yellow projections enable a comparison between the parameters. Cytocompatibility is depicted as cytotoxicity $(-)$, no effect $(0)$, or enhanced cytocompatibility $(+)$.

\subsection{Bacterial Species and Strains}

Antibacterial results are affected by the tested bacterial species. Of the reviewed studies, $57 \%$ used S. aureus, $31 \%$ E. coli, and $12 \%$ other bacterial species, including $S$. epidermidis [63,86], S. sanguinis [61], S. mutans [57,85], P. aeruginosa [82], and P. gingivalis [64]. Given that $\mathrm{Ag}, \mathrm{Cu}$, and $\mathrm{Zn}$ form an alternative to antibiotics, it is important to analyze the results on antibiotic resistant bacteria, such as MRSA, which are involved in up to $32 \%$ of fracture-related infections [140,141]. MRSA was investigated in 9 studies and 
found to be strongly inhibited by Ag [15,31,32,50,65], Ag and $\mathrm{Cu}$ [19], Ag and $\mathrm{Zn} \mathrm{[20],}$ $\mathrm{Cu}$ and $\mathrm{Zn}$ [88] bearing surfaces, while one study that included $\mathrm{Zn}$ surfaces did not observe any inhibition [86]. Thukkaram et al. observed that the antibacterial effect of Ag containing surfaces against MRSA was lower compared to S. aureus and E. coli, although with increasing doses of $\mathrm{Ag}$, all bacterial species were targeted equally [65]. Furthermore, testing on multiple species was performed in $19 \%$ of the included studies. No studies tested multiple species in a single experiment (i.e., co-culture of multiple species), which would be of interest given that $10-20 \%$ of IAI are induced by polymicrobial infections $[142,143]$.

We can, thus, conclude that most studies investigated antibacterial behavior against $S$. aureus. This bacterial species causes $20-46 \%$ of IAI [144-146]. Other gram-positive species, such as Streptococci caused up to 10\% and Enterococci 3-7\% of cases [147]. Enterococci have not been tested in studies with PEO-treated surfaces bearing Ag, $\mathrm{Cu}$, or $\mathrm{Zn}$. Gramnegative bacteria, such as Pseudomonas aeruginosa and Enterobacteriaceae induce 6-17\% of IAI $[143,148]$. Given the relatively low rate of IAI induced by Enterobacteriaceae, it is surprising that $31 \%$ of the studies investigated the effects of the implant surfaces on E. coli. While some studies that analyzed both $S$. aureus and E. coli reported a stronger antibacterial effect against $E$. coli as compared to $S$. aureus $[49,51,55,65,83,98]$, others reported a similar antibacterial effect for both species $[35,37,70,74,84,88]$. Interestingly, up to $42 \%$ of IAI in patients were caused by culture-negative (i.e., undefined) bacteria $[149,150]$ and therefore warrant an antibacterial agent effective against a wide antimicrobial spectrum.

Among bacterial species, different levels of sensitivity to antibacterial agents have been reported [151], including against $\mathrm{Ag}$ and $\mathrm{Cu}$ [152]. To what extent the differences between strains plays a role depends on the bacterial species. The differences between strains in terms of their MIC/MBC values was found to be negligible for S. aureus, but were quite large in the case of E. coli strains [153]. It is, therefore, important that the bacterial strain is properly reported, which was done only in $79 \%$ of the included studies. Only one study, conducted by Leśniak-Ziółkowska et al., compared different strains within a bacterial species, namely S. aureus (ATCC 25,923 and clinical MRSA 1030) and S. epidermidis (ATCC 700,296 and clinical 15560) [86]. No strain-dependent differences were observed after $4 \mathrm{~h}$ using a bacterial adhesion test.

\subsection{Source of Antibacterial Agent}

Antibacterial behavior depends not exclusively on the antibacterial agent, but also on the form in which $\mathrm{Ag}, \mathrm{Cu}$, and $\mathrm{Zn}$ are added to the PEO electrolyte and are subsequently incorporated onto the titanium implant surface [124]. Ag, $\mathrm{Cu}$, and $\mathrm{Zn}$ elements are either completely dissolved in the electrolyte or are added in the form of NPs that form a suspension. The former will end-up in the form of chemical compounds present all over the surface, while the latter (NPs) are spread over the surface. NPs may form a reservoir from which ions are released, thereby ensuring prolonged antibacterial activity [154]. In addition, the shape of the NPs determines the antibacterial activity as the surface-to-volume ratio affects the ion release and, thus, the efficacy of the surface biofunctionalization process [155]. Ionic forms only induce antibacterial activity through the action of ions, while NPs also produce reactive oxygen species and induce contact-killing [156]. Among the included studies, $33 \%$ used NPs, $64 \%$ employed ionic species, and only a study by Zhang et al., combined ions and NPs [87]. This study combined Ag NPs with Zn acetate, which resulted in much higher release of $\mathrm{Zn}$ ions compared to Ag ions. Furthermore, the antibacterial activity was assessed against both adherent and planktonic S. aureus after $24 \mathrm{~h}$. The developed surface demonstrated significant antibacterial behavior with increasing concentrations of $\mathrm{Ag}$ and $\mathrm{Zn}$ leading to further reduction of viable bacteria. The authors reasoned that the antibacterial activity stems from ROS generation by both $\mathrm{Ag}$ and $\mathrm{Zn}$ as well as $\mathrm{Ag}^{+}$release. Moreover, both $\mathrm{Ag}$ and $\mathrm{Zn}$ ion concentrations remained below cytotoxicity levels and thus stressed the utility of combining these elements. Studies that investigate the differences in the antibacterial properties induced by NP and ionic forms are lacking. 


\subsection{Analysis Method}

Antibacterial properties can be investigated by different assays. Properties often investigated are the antibacterial leaching activity, the killing of adherent bacteria, and the prevention of biofilm formation. Although most of the included studies used only one antibacterial assay (53\%), the use of several assays is required for the assessment of the various types of antibacterial properties [157]. Therefore, 32,8 , and $8 \%$ of the included studies used 2, 3, and 4 assays, respectively. To determine the leaching effects of the antibacterial ions released from the PEO surfaces, a zone of inhibition assay or a KirbyBauer assay is often used. The number of bacteria can be quantified either through a direct CFU count, by spread plate analysis, or by staining the live cells using a fluorescent dye. A few studies referred to ISO [51,59] and ASTM $[37,76,78]$ standards. With SEM, adherent bacteria and/or biofilm formation can be visualized in a non-quantitative manner. A wide variety in the type of assays used in the studies was found, with spread plate analysis $(33 \%)$, SEM $(24 \%)$, and viability fluorescence imaging $(12 \%)$ being the most frequently applied assays.

In addition to in vitro assays, ex vivo models were explored, in which infected implants biofunctionalized with $\mathrm{Ag}$ and $\mathrm{Cu}, \mathrm{Zn}$, or $\mathrm{Sr}$ are inserted into a murine femur $[19,20,31,50]$. Subsequently, the number of CFU present are quantified (e.g., after 24 h). Although this ex vivo model does not allow to assess the effects of the implants on the immune system or bony ingrowth, some of the other in vivo effects such as those of the extracellular matrix and bone tissue [158] can be captured to some extent. Indeed, the gene expression profile of osteocytes was found to be similar between an ex vivo bone infection model and tissue samples from IAI patients [159]. Thus far, no study has tested the antibacterial activity of titanium implants biofunctionalized by $\mathrm{PEO}$ with $\mathrm{Ag}, \mathrm{Cu}$, and $\mathrm{Zn}$ in vivo.

\subsection{Duration and Inoculum of Antibacterial Assay}

Over two thirds of IAIs are initiated during surgery [160]. A rapid antibacterial response to prevent the adherence of the bacteria that enter the human body peri-operatively is, therefore, desired. Almost all of the included studies (94\%) tested the antibacterial properties within $24 \mathrm{~h}$ and $10 \%$ even within $2 \mathrm{~h}$. However, IAI can also be initiated long after surgery, stemming from hematogenous origins. Prolonged antibacterial activity is, thus, desirable too $[72,85,161]$. Zhang et al., reported on the antibacterial activity of $\mathrm{Cu}$ containing surfaces for longer periods of time [72]. It was observed that the number of viable adherent bacteria was significantly reduced on surfaces containing $0.67-1.98 \mathrm{wt} \%$ $\mathrm{Cu}$ up to $96 \mathrm{~h}$. However, this was one of the few studies aiming to assess long-term antibacterial behavior, since prolonged in vitro culture of bacteria is challenging. Research into late IAI is, therefore, primarily performed in vivo [162,163].

The inoculum used in the antibacterial assays is another factor determining the antibacterial behavior of PEO-biofunctionalized implants. The exact number of bacteria required for IAI is unknown, but it was shown that the presence of a foreign body can reduce the infection dose by 6 orders of magnitude [164] due to a hampered immune response [165]. The inoculum used in the included studies varied widely between 250 [53] and $10^{9} \mathrm{CFU} / \mathrm{mL}[58,85]$, and was not reported in two studies. Currently, most inocula are presented per volume or as a measure of optical density. However, the surface area of the implant is also of importance, as more area with more incorporated antibacterial agent is likely to have a greater antibacterial effect. Therefore, presenting the inoculum per volume per surface area would support comparative analyses of different studies.

\subsection{Planktonic vs. Adherent Bacteria}

As both planktonic and adherent bacteria play an important role in IAIs, antibacterial implants should target both types of bacteria. Planktonic bacteria are present in the fluid and tissue surrounding the implant and have shown to be a reservoir for late-stage reinfections [125]. Once the bacteria adhere to the implant, bacteria should be targeted in 
order to prevent biofilm formation as this would induce bacterial resistance to antibiotic treatment [166]. In this respect, $42 \%$ of the included studies investigated antibacterial activity against adherent, $35 \%$ against planktonic, and $23 \%$ against both planktonic and adherent bacteria. Targeting both planktonic and adherent bacteria should, therefore, be emphasized more in future studies.

\section{Biocompatibility}

In addition to antibacterial properties, PEO-biofunctionalized implant surfaces should not induce cytotoxicity, and ideally even enhance cell response and bony ingrowth. The compatibility of the implants with mammalian cells is, therefore, an important topic that needs to be thoroughly investigated for any such implant. Several of the included studies report the results of such in vitro cytocompatibility experiments, which are affected by the type of the assay, cell type, and cell source (Supplementary Table S1).

\subsection{Cytocompatibility of $\mathrm{Ag}, \mathrm{Cu}$, and $\mathrm{Zn}$ Surfaces}

Cytocompatibility was investigated in $71 \%$ of studies. In those studies, $\mathrm{Ag}$ induced cytotoxicity in $13 \%$ of the studies, while $10 \%$ of the studies investigating $\mathrm{Cu}$ and $0 \%$ of those employing $\mathrm{Zn}$ reported cytotoxic effects. None of the studies combining $\mathrm{Ag}, \mathrm{Cu}$, and $\mathrm{Zn}$ reported cytotoxicity. Cell response of the implants was improved in $7 \%$ of the studies using $\mathrm{Ag}$, $50 \%$ of the studies focused on $\mathrm{Cu}$, and $33 \%$ of the studies with $\mathrm{Zn}$, as well as for $50 \%$ of the studies in which two or more antibacterial agents were combined. The control group often consists of PEO biofunctionalized surfaces without antibacterial elements. Cytotoxicity is, therefore, not considered a major concern by the vast majority of the included studies. Indeed, $\mathrm{Cu}$ and to somewhat lesser extent $\mathrm{Zn}$ were shown to improve the cytocompatibility of PEO-treated implants.

\subsection{Type of Assay}

Several processes that occur in bone regeneration were investigated in vitro. Cells need to attach to the implant surface [167], spread [168], stay viable [169], proliferate, differentiate towards the osteogenic lineage [170], and eventually form an extracellular matrix [171]. Indicators for the bone regeneration process include cell morphology [172], expression of osteogenic markers [173], metabolic activity [174], and the production of specific proteins [175]. The parameters studied the most in the included studies were viability and proliferation (analyzed in $56 \%$ of the included studies), followed by adhesion and attachment $(36 \%)$, differentiation $(25 \%)$, cell spreading $(22 \%)$, matrix calcification and mineralization $(11 \%)$, metabolic activity $(8 \%)$, gene expression $(8 \%)$, morphology $(3 \%)$, cell seeding $(3 \%)$, and other assays $(6 \%)$ including protein production, mitochondrial functioning, and cytokine production.

\subsection{Cell Type}

The cellular response was shown to differ in in vitro experiments between different cell types $[176,177]$. In the reviewed studies, pre-osteoblasts $(32 \%)$, osteosarcoma cells $(22 \%)$, fibroblasts $(20 \%)$, MSCs (17\%) and SV-HFO, macrophages, adipose stem cells, and endothelial cells (each in 1 study) were used. Pre-osteoblasts and MSCs are the main cells responsible for bone formation [178,179]. Osteosarcoma and SV-HFO cells [180] are immortalized cells stemming from the osteogenic lineage. However, osteosarcoma was shown to stem from defective differentiation [181]. Since these titanium implants will be used in bone tissue, it was surprising that $29 \%$ of the studies did not analyze the effects of the implants on bone-forming cells. Other cell types may support bone formation through indirect pathways. Endothelial cells play a role in angiogenesis, which plays a major role in bone regeneration as blood vessels carry nutrients and oxygen and facilitate the transport of immune cells to the regenerating bone tissue [182]. Meanwhile, macrophages form an important part of the immune response against IAI. Any potential toxicity of the synthesized implants against this cell type is of concern, as it may hamper the clearance of 
infections $[16,183]$. Finally, fibroblasts were shown to regulate osteoblast activity through tight junction interactions [184].

\subsection{Cell Source}

About $22 \%$ of the included studies used primary cells, whereas $78 \%$ utilized cell lines. Primary cells are more representative of the clinical situation, as they have been isolated from donors. However, their variability is high. Cells from multiple donors, therefore, need to be tested [185]. Cell lines, on the other hand, are homogenous and stable, while exhibiting little variability. However, their immortalized nature makes them differ from the clinical situation [186]. Furthermore, the source of animal species from which the cells were derived differed greatly between the included studies, with $56 \%$ using murine cells, $34 \%$ human cells, and $10 \%$ rat cells. The osteogenic differentiation capacity of stem cells is known to differ between human, mice, and rat MSCs $[187,188]$. These differences in animal species make it difficult (if not impossible) to directly compare the cytocompatibility results reported in the different studies.

\section{Discussion}

In order to prevent IAI, the biofunctionalization of titanium implants by PEO using $\mathrm{Ag}, \mathrm{Cu}$, and $\mathrm{Zn}$ as the active agents has gained significant momentum in the last decade. Therefore, we systematically reviewed the progress made on those implants and summarized the various types of properties measured for such types of PEO-biofunctionalized implants.

\subsection{Antibacterial Results}

From the results of this study, it can be concluded that Ag is the most potent antibacterial agent followed by $\mathrm{Cu}$ and $\mathrm{Zn}$. It is important to stress that different studies utilized different experimental protocols to determine the antibacterial properties of PEObiofunctionalized implants. It was shown that titanium surfaces bearing $\mathrm{Ag}, \mathrm{Cu}$, and $\mathrm{Zn}$ can kill bacteria through antibacterial leaching activity, contact killing, and the formation of ROS [156,189]. These properties cannot be assessed in a single assay. The use of multiple assays is, therefore, warranted to support the claim of antibacterial activity [157]. Finally, it is important to make sure that the assays assess infection prevention rather than infection treatment.

Furthermore, the bacterial species and strains used were found to affect the level of antibacterial activity. For instance, surfaces demonstrating antibacterial activity against E. coli may not do the same against $S$. aureus $[51,55,98]$. Most studies investigated the antibacterial activity of the implants against $S$. aureus or $E$. coli. While a large proportion of IAI was induced by $S$. aureus, only a small proportion of infections were caused by $E$. coli $[144,147]$. The rationale for choosing E. coli was, thus, primarily methodological convenience rather than clinical prevalence. Meanwhile, S. epidermidis or polymicrobial infections were rarely studied, even though they cause a significant proportion of IAI [142-144]. Moreover, the antibacterial behavior of PEO-biofunctionalized implants should be assessed in environments co-habited by multiple bacterial species, as this was shown to influence the resistance profiles of bacteria [130].

The antibacterial experiments aimed to mimic the clinical situation as closely as possible. In this respect, both adherent and planktonic bacteria should be warded off, as adherent bacteria can form biofilms [133], while planktonic bacteria may infect the peri-implant tissue and form a reservoir for late-stage reinfection [125]. Furthermore, an antibacterial implant should prevent infections that occur immediately after surgery, as that is the point where most IAI occur [160], as well as late-stage infections from hematogenous origins [161]. At the moment, the focus primarily lies on preventing early-stage infections. Ultimately, $\mathrm{Ag}$, $\mathrm{Cu}$, and $\mathrm{Zn}$ may form an alternative to antibiotics, as bacteria are developing ever-growing degrees of antibiotics resistance $[144,190]$. As such, the development of resistance against 
$\mathrm{Ag}, \mathrm{Cu}$, and $\mathrm{Zn}$ and combination thereof is worthwhile to investigate given that resistance against $\mathrm{Ag}$, $\mathrm{Cu}$, and $\mathrm{Zn}$ was reported in vitro [191-193] and in patients [194].

The observed antibacterial activity depends on a wide variety of factors described in this review, including the titanium substrate, composition of the PEO electrolyte, and PEO processing parameters that in turn affect the surface morphology, phase composition, surface content of the incorporated antibacterial agent, and ion release profile. These parameters determine the antibacterial properties and biocompatibility of the implants. The measured antibacterial properties are highly dependent on the bacterial species and strains used, experimental techniques, the duration of the assays, bacterial inoculum, and the type of bacteria against which the implant performance is measured (i.e., planktonic and/or adherent). As for biocompatibility, the type of the assays, cell type, and cell source could all influence the final read-outs. These factors varied between the studies included in this review and make a one-to-one comparison between the different studies challenging.

The antibacterial activity is dependent on the dose of $\mathrm{Ag}, \mathrm{Cu}$, and $\mathrm{Zn}$ present on the surface of the titanium implants [119-121]. It is, therefore, essential to determine the amount of these elements present on the surface. In addition, the $\mathrm{Ag}, \mathrm{Cu}$, and $\mathrm{Zn}$ ions released from the implant surface are responsible for a significant part of the antibacterial activity, which is why it is important to measure the concentration of the ions released from the implant surface. From the results, it is clear that the surfaces bearing Ag had much lower elemental content and ion release as compared to those bearing $\mathrm{Cu}$ and $\mathrm{Zn}$, which was expected due to the lower MIC of Ag as compared to $\mathrm{Cu}$ and $\mathrm{Zn}$ [122]. Both the surface content and ion release were also dependent on the surface area, as a larger surface area allows for the incorporation of a greater amount of elements and, thus, increased ion release [31]. Therefore, describing these properties relative to the surface area may aid in a comparison between the results of different studies.

\subsection{Biocompatibility}

Most of the included studied found cytotoxicity to be a minor concern, with Ag inducing cytotoxicity in $13 \%$ of the studies. It was striking that $29 \%$ of the included studies did not investigate the effects of the implants on bone-forming cells, even though the implants are intended for bone tissue. In addition, cytotoxicity against other cell types, such as endothelial cells and immune cells is of interest, as these cells contribute to bone regeneration as well $[195,196]$. Furthermore, the use of cell lines vs. donor cells and different mammalian species complicates the comparisons between different studies [197]. Moreover, biocompatibility needs to be investigated both in vitro and in vivo, as the results of in vitro and in vivo experiments are known to differ, for instance, in the case of Agbearing surfaces [16].

Another way to enhance the cytocompatibility of PEO-biofunctionalized implants is by combining two or more antibacterial metals (i.e., $\mathrm{Ag}, \mathrm{Cu}$, and $\mathrm{Zn}$ ), as synergic effects between various such agents are reported to exist $[19,20]$ and could be used to reduce the concentration of $\mathrm{Ag}[126,198]$. In addition, combining these elements with other osteogenic elements, such as Sr [50] may enhance their antibacterial and biocompatible properties. Finally, the combination of multiple antibacterial elements significantly reduces the risk of the development of bacterial resistance, thereby ensuring that the prolonged use of these elements will remain possible [199].

PEO is frequently applied in combination with other surface treatments, such as hydrothermal treatment [200] and physical vapor deposition [201] to alter the chemical and phase composition of the surface. This may result in improved antibacterial behavior [98]. Furthermore, hydrothermal treatment has resulted in the enhanced formation of hydroxyapatite crystals, yet may reduce corrosion resistance too [202]. A major disadvantage of these additional surface treatments is that they make the entire process lengthier and more complex, thus making it more difficult to upscale the production of clinically sized implants. 


\subsection{Towards Clinically Relevant Implants}

A decade of $\mathrm{PEO}$ biofunctionalization of titanium implants with $\mathrm{Ag}, \mathrm{Cu}$, and $\mathrm{Zn}$ confirmed the great potential of this method as an effective, fast, and scalable process. At the moment, however, the research on antibacterial PEO-biofunctionalized titanium implants is still far away from clinical application, as the research was primarily conducted in vitro with few studies also exploring ex vivo models [20,50]. Furthermore, PEO was shown to enhance the osteogenic capacity of titanium implants in vivo [38,39,203], including surfaces bearing $\mathrm{Zn}$ [204]. However, these studies did not analyze the antibacterial properties of such implants, which should be evaluated using bone infection models [205]. In this respect, a major limitation of the state-of-the-art techniques is their limited relevance for the assessment of the preventive potential of antibacterial implants (as opposed to their treatment potential). However, studying prevention requires a much larger sample size, as it is associated with lower bacterial loads, meaning that infections are less likely to occur. This lower risk of infection has major ethical and financial implications. In addition, future implants will most likely be fabricated by AM and as such be highly porous. Not only is the risk of infection of such volume-porous implants higher, their IAI treatment is also highly challenging due to their usually high degree of bony ingrowth that may cause significant bone loss during their removal. The development of antibacterial surface treatments for such types of implants is, thus, highly relevant. In fact, the additional surface area of such implants may be exploited to enhance the bioactivity of PEO biofunctionalized implants [31].

\section{Conclusions}

In order to combat IAI, the biofunctionalization of titanium implants by $\mathrm{Ag}, \mathrm{Cu}$, and $\mathrm{Zn}$ has gained significant momentum in recent years and resulted in the synthesis of potent antibacterial and biocompatible surfaces. Implant biofunctionalized with $\mathrm{Ag}$, $\mathrm{Cu}$, and $\mathrm{Zn}$ demonstrated significant antibacterial behavior against a wide bacterial spectrum, including antibiotic-resistant bacterial strains. However, the antibacterial properties of these implants were primarily investigated in vitro and occasionally ex vivo. Furthermore, many studies do not reach sufficiently high antibacterial levels, as indicated by international guidelines. Moreover, the biofunctionalization of volume-porous AM implants has not been investigated extensively. Finally, combining $\mathrm{Ag}, \mathrm{Cu}$, and $\mathrm{Zn}$ on the surface of titanium implants was shown to result in potent antibacterial surfaces with reduced cytotoxicity. In order to take the PEO biofunctionalization of titanium implants by $\mathrm{Ag}, \mathrm{Cu}$, and $\mathrm{Zn}$ to clinical settings, in vivo studies should be conducted using relevant infection models for both solid and volume-porous bone implants.

Supplementary Materials: The following are available online at https:/ /www.mdpi.com/article/10 .3390 /ijms22073800/s1, Figure S1: Flow diagram of the systematic literature search., Table S1: The biocompatibility of PEO-modified Ti-based surfaces bearing single or multiple elements.

Funding: The research for this paper was financially supported by the Prosperos project, funded by the Interreg VA Flanders-The Netherlands program, CCI grant no. 2014TC16RFCB046.

Conflicts of Interest: The authors declare no conflict of interest.

\section{References}

1. Zimmerli, W. Clinical presentation and treatment of orthopaedic implant-associated infection. J. Intern. Med. 2014, 276, 111-119. [CrossRef]

2. Govaert, G.A.M.; Kuehl, R.; Atkins, B.L.; Trampuz, A.; Morgenstern, M.; Obremskey, W.T.; Verhofstad, M.H.J.; McNally, M.A.; Metsemakers, W.J.; Fracture-Related Infection (FRI) Consensus Group. Fracture-related infection consensus, diagnosing fracture-related infection: Current concepts and recommendations. J. Orthop. Trauma 2020, 34, 8-17. [CrossRef]

3. Kapoor, S.K.; Thiyam, R. Management of infection following reconstruction in bone tumors. J. Clin. Orthop. Trauma 2015, 6, 244-251. [CrossRef]

4. Singh, J.A. Epidemiology of knee and hip arthroplasty: A systematic review. Open Orthop. J. 2011, 5, 80-85. [CrossRef] 
5. $\quad$ Kremers, H.M.; Larson, D.R.; Crowson, C.S.; Kremers, W.K.; Washington, R.E.; Steiner, C.A.; Jiranek, W.A.; Berry, D.J. Prevalence of total hip and knee replacement in the United States. J. Bone Jt. Surg. Am. 2015, 97, 1386-1397. [CrossRef]

6. Singh, J.A.; Yu, S.; Chen, L.; Cleveland, J.D. Rates of total joint replacement in the United States: Future projections to 2020-2040 using the national inpatient sample. J. Rheumatol. 2019, 46, 1134-1140. [CrossRef]

7. Chambers, H.F.; Deleo, F.R. Waves of resistance: Staphylococcus aureus in the antibiotic era. Nat. Rev. Microbiol. $2009,7,629-641$. [CrossRef]

8. Guo, Y.; Song, G.; Sun, M.; Wang, J.; Wang, Y. Prevalence and therapies of antibiotic-resistance in Staphylococcus aureus. Front. Cell. Infect. Microbiol. 2020, 10, 107. [CrossRef]

9. Teterycz, D.; Ferry, T.; Lew, D.; Stern, R.; Assal, M.; Hoffmeyer, P.; Bernard, L.; Uckay, I. Outcome of orthopedic implant infections due to different staphylococci. Int. J. Infect. Dis. 2010, 14, e913-e918. [CrossRef]

10. Cho, O.H.; Bae, I.G.; Moon, S.M.; Park, S.Y.; Kwak, Y.G.; Kim, B.N.; Yu, S.N.; Jeon, M.H.; Kim, T.; Choo, E.J.; et al. Therapeutic outcome of spinal implant infections caused by Staphylococcus aureus: A retrospective observational study. Medicine 2018, 97, e12629. [CrossRef]

11. Gross, T.M.; Lahiri, J.; Golas, A.; Luo, J.; Verrier, F.; Kurzejewski, J.L.; Baker, D.E.; Wang, J.; Novak, P.F.; Snyder, M.J. Coppercontaining glass ceramic with high antimicrobial efficacy. Nat. Commun. 2019, 10, 1979. [CrossRef]

12. Lara, H.H.; Ayala-Núñez, N.V.; Ixtepan Turrent, L.d.C.; Rodríguez Padilla, C. Bactericidal effect of silver nanoparticles against multidrug-resistant bacteria. World J. Microbiol. Biotechnol. 2009, 26, 615-621. [CrossRef]

13. Nanda, A.; Saravanan, M. Biosynthesis of silver nanoparticles from Staphylococcus aureus and its antimicrobial activity against MRSA and MRSE. Nanomedicine 2009, 5, 452-456. [CrossRef] [PubMed]

14. Siddiqi, K.S.; Rahman, A.U.; Tajuddin; Husen, A. Properties of Zinc Oxide nanoparticles and their activity against microbes. Nanoscale Res. Lett. 2018, 13, 141. [CrossRef]

15. Necula, B.S.; Van Leeuwen, J.P.; Fratila-Apachitei, L.E.; Zaat, S.A.; Apachitei, I.; Duszczyk, J. In vitro cytotoxicity evaluation of porous $\mathrm{TiO}(2)-\mathrm{Ag}$ antibacterial coatings for human fetal osteoblasts. Acta Biomater. 2012, 8, 4191-4197. [CrossRef]

16. Croes, M.; Bakhshandeh, S.; Van Hengel, I.A.J.; Lietaert, K.; Van Kessel, K.P.M.; Pouran, B.; Van der Wal, B.C.H.; Vogely, H.C.; Van Hecke, W.; Fluit, A.C.; et al. Antibacterial and immunogenic behavior of silver coatings on additively manufactured porous titanium. Acta Biomater. 2018, 81, 315-327. [CrossRef]

17. Bergemann, C.; Zaatreh, S.; Wegner, K.; Arndt, K.; Podbielski, A.; Bader, R.; Prinz, C.; Lembke, U.; Nebe, J.B. Copper as an alternative antimicrobial coating for implants-An in vitro study. World J. Transpl. 2017, 7, 193-202. [CrossRef] [PubMed]

18. Ding, Q.; Zhang, X.; Huang, Y.; Yan, Y.; Pang, X. In vitro cytocompatibility and corrosion resistance of zinc-doped hydroxyapatite coatings on a titanium substrate. J. Mater. Sci. 2014, 50, 189-202. [CrossRef]

19. Van Hengel, I.A.J.; Tierolf, M.; Valerio, V.P.M.; Minneboo, M.; Fluit, A.C.; Fratila-Apachitei, L.E.; Apachitei, I.; Zadpoor, A.A. Self-defending additively manufactured bone implants bearing silver and copper nanoparticles. J. Mater. Chem. B 2020, 8 , 1589-1602. [CrossRef]

20. Van Hengel, I.A.J.; Putra, N.E.; Tierolf, M.; Minneboo, M.; Fluit, A.C.; Fratila-Apachitei, L.E.; Apachitei, I.; Zadpoor, A.A. Biofunctionalization of selective laser melted porous titanium using silver and zinc nanoparticles to prevent infections by antibiotic-resistant bacteria. Acta Biomater. 2020, 107, 325-337. [CrossRef]

21. Yoshitani, J.; Kabata, T.; Arakawa, H.; Kato, Y.; Nojima, T.; Hayashi, K.; Tokoro, M.; Sugimoto, N.; Kajino, Y.; Inoue, D.; et al. Combinational therapy with antibiotics and antibiotic-loaded adipose-derived stem cells reduce abscess formation in implant-related infection in rats. Sci. Rep. 2020, 10, 11182. [CrossRef] [PubMed]

22. Cavanaugh, D.L.; Berry, J.; Yarboro, S.R.; Dahners, L.E. Better prophylaxis against surgical site infection with local as well as systemic antibiotics. An in vivo study. J. Bone Jt. Surg. Am. 2009, 91, 1907-1912. [CrossRef]

23. Metsemakers, W.J.; Fragomen, A.T.; Moriarty, T.F.; Morgenstern, M.; Egol, K.A.; Zalavras, C.; Obremskey, W.T.; Raschke, M.; McNally, M.A.; Fracture-Related Infection (FRI) Consensus Group. Evidence-based recommendations for local antimicrobial strategies and dead space management in fracture-related infection. J. Orthop. Trauma 2020, 34, 18-29. [CrossRef]

24. Celis, J.P.; Drees, D.; Huq, M.Z.; Wu, P.Q.; De Bonte, M. Hybrid processes-A versatile technique to match process requirements and coating needs. Surf. Coat. Technol. 1999, 113, 165-181. [CrossRef]

25. Kumar, R.; Munstedt, H. Silver ion release from antimicrobial polyamide/silver composites. Biomaterials 2004, 26, 2081-2088. [CrossRef]

26. Zaporojtchenko, V.; Podschun, R.; Schurmann, U.; Kulkarni, A.; Faupel, F. Physico-chemical and antimicrobial properties of co-sputtered Ag-Au/PTFE nanocomposite coatings. Nanotechnology 2006, 17, 4904-4908. [CrossRef]

27. Gollwitzer, H.; Haenle, M.; Mittelmeier, W.; Heidenau, F.; Harasser, N. A biocompatible sol-gel derived titania coating for medical implants with antibacterial modification by copper integration. AMB Express 2018, 8, 1-9. [CrossRef] [PubMed]

28. Su, Y.; Wang, K.; Gao, J.; Yang, Y.; Qin, Y.; Zheng, Y.; Zhu, D. Enhanced cytocompatibility and antibacterial property of zinc phosphate coating on biodegradable zinc materials. Acta Biomater. 2019, 98, 174-185. [CrossRef]

29. Cao, H.; Liu, X.; Meng, F.; Chu, P.K. Biological actions of silver nanoparticles embedded in titanium controlled by micro-galvanic effects. Biomaterials 2011, 32, 693-705. [CrossRef]

30. Piwonski, I.; Kadzioła, K.; Kisielewska, A.; Soliwoda, K.; Wolszczak, M.; Lisowska, K.; Wronska, N.; Felczak, A. The effect of the deposition parameters on size, distribution and antimicrobial properties of photoinduced silver nanoparticles on titania coatings. Appl. Surf. Sci. 2011, 257, 7076-7082. [CrossRef] 
31. Van Hengel, I.A.J.; Riool, M.; Fratila-Apachitei, L.E.; Witte-Bouma, J.; Farrell, E.; Zadpoor, A.A.; Zaat, S.A.J.; Apachitei, I. Selective laser melting porous metallic implants with immobilized silver nanoparticles kill and prevent biofilm formation by methicillin-resistant Staphylococcus aureus. Biomaterials 2017, 140, 1-15. [CrossRef] [PubMed]

32. Necula, B.S.; Fratila-Apachitei, L.E.; Zaat, S.A.; Apachitei, I.; Duszczyk, J. In vitro antibacterial activity of porous TiO2-Ag composite layers against methicillin-resistant Staphylococcus aureus. Acta Biomater. 2009, 5, 3573-3580. [CrossRef]

33. Rizwan, M.; Alias, R.; Zaidi, U.Z.; Mahmoodian, R.; Hamdi, M. Surface modification of valve metals using plasma electrolytic oxidation for antibacterial applications: A review. J. Biomed. Mater. Res. A 2018, 106, 590-605. [CrossRef]

34. Asharani, P.V.; Low Kah Mun, G.; Prakash Hande, M.; Valiyaveettil, S. Cytotoxicity and genotoxicity of silver nanoparticles in human cells. ACS Nano 2009, 3, 279-290. [CrossRef]

35. Song, W.H.; Ryu, H.S.; Hong, S.H. Antibacterial properties of Ag (or Pt)-containing calcium phosphate coatings formed by micro-arc oxidation. J. Biomed. Mater. Res. A 2009, 88, 246-254. [CrossRef] [PubMed]

36. Zhu, W.; Zhang, Z.; Gu, B.; Sun, J.; Zhu, L. Biological activity and antibacterial property of nano-structured TiO2 coating incorporated with $\mathrm{Cu}$ prepared by micro-arc oxidation. J. Mater. Sci. Technol. 2013, 29, 237-244. [CrossRef]

37. Roknian, M.; Fattah-Alhosseini, A.; Gashti, S.O.; Keshavarz, M.K. Study of the effect of ZnO nanoparticles addition to PEO coatings on pure titanium substrate: Microstructural analysis, antibacterial effect and corrosion behavior of coatings in Ringer's physiological solution. J. Alloy. Compd. 2018, 740, 330-345. [CrossRef]

38. Santos-Coquillat, A.; Martínez-Campos, E.; Mohedano, M.; Martínez-Corriá, R.; Ramos, V.; Arrabal, R.; Matykina, E. In vitro and in vivo evaluation of PEO-modified titanium for bone implant applications. Surf. Coat. Technol. 2018, 347, 358-368. [CrossRef]

39. Chung, C.J.; Su, R.T.; Chu, H.J.; Chen, H.T.; Tsou, H.K.; He, J.L. Plasma electrolytic oxidation of titanium and improvement in osseointegration. J. Biomed. Mater. Res. B Appl. Biomater. 2013, 101, 1023-1030. [CrossRef]

40. Martin, J.; Melhem, A.; Shchedrina, I.; Duchanoy, T.; Nominé, A.; Henrion, G.; Czerwiec, T.; Belmonte, T. Effects of electrical parameters on plasma electrolytic oxidation of aluminium. Surf. Coat. Technol. 2013, 221, 70-76. [CrossRef]

41. Van Hengel, I.A.J.; Laçin, M.; Minneboo, M.; Fratila-Apachitei, L.E.; Apachitei, I.; Zadpoor, A.A. The effects of plasma electrolytically oxidized layers containing $\mathrm{Sr}$ and $\mathrm{Ca}$ on the osteogenic behavior of selective laser melted Ti6Al4V porous implants. J. Mater. Sci. Eng. C 2021, 124. [CrossRef]

42. Clyne, T.W.; Troughton, S.C. A review of recent work on discharge characteristics during plasma electrolytic oxidation of various metals. Int. Mater. Rev. 2018, 64, 127-162. [CrossRef]

43. Moher, D.; Liberati, A.; Tetzlaff, J.; Altman, D.G. Preferred reporting items for systematic reviews and meta-analyses: The PRISMA statement. PLoS Med. 2009, 6, e1000097. [CrossRef] [PubMed]

44. Yerokhin, A.L.; Nie, X.; Leyland, A.; Matthews, A.; Dowey, S.J. Plasma electrolysis for surface engineering. Surf. Coat. Technol. 1999, 122, 73-93. [CrossRef]

45. Curran, J.A.; Clyne, T.W. Thermo-physical properties of plasma electrolytic oxide coatings on aluminium. Surf. Coat. Technol. 2005, 199, 168-176. [CrossRef]

46. Wang, Y.; Yu, H.; Chen, C.; Zhao, Z. Review of the biocompatibility of micro-arc oxidation coated titanium alloys. Mater. Des. 2015, 85, 640-652. [CrossRef]

47. Matykina, E.; Skeldon, P.; Thompson, G.E. Fundamental and practical evaluations of PEO coatings of titanium. Int. Heat Treat. Surf. Eng. 2013, 3, 45-51. [CrossRef]

48. Zhang, L.; Li, B.; Zhang, X.; Wang, D.; Zhou, L.; Li, H.; Liang, C.; Liu, S.; Wang, H. Biological and antibacterial properties of TiO2 coatings containing Ca/P/Ag by one-step and two-step methods. Biomed. Microdevices 2020, 22, 24. [CrossRef]

49. Thukkaram, M.; Cools, P.; Nikiforov, A.; Rigole, P.; Coenye, T.; Van Der Voort, P.; Du Laing, G.; Vercruysse, C.; Declercq, H.; Morent, R.; et al. Antibacterial activity of a porous silver doped TiO2 coating on titanium substrates synthesized by plasma electrolytic oxidation. Appl. Surf. Sci. 2020, 500. [CrossRef]

50. Van Hengel, I.A.J.; Gelderman, F.S.A.; Athanasiadis, S.; Minneboo, M.; Weinans, H.; Fluit, A.C.; Van der Eerden, B.C.J.; FratilaApachitei, L.E.; Apachitei, I.; Zadpoor, A.A. Functionality-packed additively manufactured porous titanium implants. Materials Today Bio 2020, 7. [CrossRef]

51. Shimabukuro, M.; Tsutsumi, Y.; Yamada, R.; Ashida, M.; Chen, P.; Doi, H.; Nozaki, K.; Nagai, A.; Hanawa, T. Investigation of realizing both antibacterial property and osteogenic cell compatibility on titanium surface by simple electrochemical treatment. ACS Biomater. Sci. Eng. 2019, 5, 5623-5630. [CrossRef]

52. Sedelnikova, M.B.; Komarova, E.G.; Sharkeev, Y.P.; Ugodchikova, A.V.; Mushtovatova, L.S.; Karpova, M.R.; Sheikin, V.V.; Litvinova, L.S.; Khlusov, I.A. Zn-, Cu- or Ag-incorporated micro-arc coatings on titanium alloys: Properties and behavior in synthetic biological media. Surf. Coat. Technol. 2019, 369, 52-68. [CrossRef]

53. Sedelnikova, M.B.; Komarova, E.G.; Sharkeev, Y.P.; Ugodchikova, A.V.; Tolkacheva, T.V.; Rau, J.V.; Buyko, E.E.; Ivanov, V.V.; Sheikin, V.V. Modification of titanium surface via Ag-, Sr- and Si-containing micro-arc calcium phosphate coating. Bioact. Mater. 2019, 4, 224-235. [CrossRef]

54. Lv, Y.; Wu, Y.; Lu, X.; Yu, Y.; Fu, S.; Yang, L.; Dong, Z.; Zhang, X. Microstructure, bio-corrosion and biological property of Ag-incorporated TiO2 coatings: Influence of Ag2O contents. Ceram. Int. 2019, 45, 22357-22367. [CrossRef]

55. Teker, D.; Muhaffel, F.; Menekse, M.; Karaguler, N.G.; Baydogan, M.; Cimenoglu, H. Characteristics of multi-layer coating formed on commercially pure titanium for biomedical applications. Mater. Sci. Eng. C Mater. Biol. Appl. 2015, 48, 579-585. [CrossRef] [PubMed] 
56. Teker Aydogan, D.; Muhaffel, F.; Menekse Kilic, M.; Karabiyik Acar, O.; Cempura, G.; Baydogan, M.; Karaguler, N.G.; Torun Kose, G.; Czyrska-Filemonowicz, A.; Cimenoglu, H. Optimisation of micro-arc oxidation electrolyte for fabrication of antibacterial coating on titanium. Mater. Technol. 2017, 33, 119-126. [CrossRef]

57. Dilek Aydogan, T.; Muhaffel, F.; Acar, O.K.; Topcuoglu, E.N.; Kulekci, H.G.; Kose, G.T.; Baydogan, M.; Cimenoglu, H. Surface modification of Ti6Al4V by micro-arc oxidation in AgC2H3O2-containing electrolyte. Surf. Innov. 2018, 6, 277-285. [CrossRef]

58. Muhaffel, F.; Cempura, G.; Menekse, M.; Czyrska-Filemonowicz, A.; Karaguler, N.; Cimenoglu, H. Characteristics of multi-layer coatings synthesized on Ti6Al4V alloy by micro-arc oxidation in silver nitrate added electrolytes. Surf. Coat. Technol. 2016, 307, 308-315. [CrossRef]

59. Tsutsumi, Y.; Niinomi, M.; Nakai, M.; Shimabukuro, M.; Ashida, M.; Chen, P.; Doi, H.; Hanawa, T. Electrochemical surface treatment of a $\beta$-titanium alloy to realize an antibacterial property and bioactivity. Metals 2016, 6, 76. [CrossRef]

60. Shin, K.R.; Kim, Y.S.; Kim, G.W.; Yang, H.W.; Ko, Y.G.; Shin, D.H. Effects of concentration of Ag nanoparticles on surface structure and in vitro biological responses of oxide layer on pure titanium via plasma electrolytic oxidation. Appl. Surf. Sci. 2015, 347, 574-582. [CrossRef]

61. Marques, I.D.; Barao, V.A.; Da Cruz, N.C.; Yuan, J.C.; Mesquita, M.F.; Ricomini-Filho, A.P.; Sukotjo, C.; Mathew, M.T. Electrochemical behavior of bioactive coatings on cp-Ti surface for dental application. Corros. Sci. 2015, 100, 133-146. [CrossRef]

62. Da Silva Viera Marques, I.; Alfaro, M.F.; Saito, M.T.; Da Cruz, N.C.; Takoudis, C.; Landers, R.; Mesquita, M.F.; Nociti, F.H., Jr.; Mathew, M.T.; Sukotjo, C.; et al. Biomimetic coatings enhance tribocorrosion behavior and cell responses of commercially pure titanium surfaces. Biointerphases 2016, 11, 031008. [CrossRef]

63. Gasquères, C.; Schneider, G.; Nusko, R.; Maier, G.; Dingeldein, E.; Eliezer, A. Innovative antibacterial coating by anodic spark deposition. Surf. Coat. Technol. 2012, 206, 3410-3414. [CrossRef]

64. Zhou, L.; Lü, G.-H.; Mao, F.-F.; Yang, S.-Z. Preparation of biomedical Ag incorporated hydroxyapatite/titania coatings on Ti6Al4V alloy by plasma electrolytic oxidation. Chin. Phys. B 2014, 23. [CrossRef]

65. Thukkaram, M.; Coryn, R.; Asadian, M.; Esbah Tabaei, P.S.; Rigole, P.; Rajendhran, N.; Nikiforov, A.; Sukumaran, J.; Coenye, T.; Van Der Voort, P.; et al. Fabrication of microporous coatings on titanium implants with improved mechanical, antibacterial, and cell-interactive properties. ACS Appl. Mater. Interfaces 2020, 12, 30155-30169. [CrossRef]

66. Oleshko, O.; Liubchak, I.; Husak, Y.; Korniienko, V.; Yusupova, A.; Oleshko, T.; Banasiuk, R.; Szkodo, M.; Matros-Taranets, I.; Kazek-Kesik, A.; et al. In vitro biological characterization of silver-doped anodic oxide coating on titanium. Materials 2020, 13, 4359. [CrossRef] [PubMed]

67. Zhao, Q.; Yi, L.; Hu, A.; Jiang, L.; Hong, L.; Dong, J. Antibacterial and osteogenic activity of a multifunctional microporous coating codoped with $\mathrm{Mg}, \mathrm{Cu}$ and F on titanium. J. Mater. Chem. B 2019, 7, 2284-2299. [CrossRef] [PubMed]

68. Zhang, X.; Peng, Z.; Lu, X.; Lv, Y.; Cai, G.; Yang, L.; Dong, Z. Microstructural evolution and biological performance of Cuincorporated $\mathrm{TiO} 2$ coating fabricated through one-step micro-arc oxidation. Appl. Surf. Sci. 2020, 508. [CrossRef]

69. Rokosz, K.; Hryniewicz, T.; Kacalak, W.; Tandecka, K.; Raaen, S.; Gaiaschi, S.; Chapon, P.; Malorny, W.; Matysek, D.; Pietrzak, K.; et al. Porous coatings containing copper and phosphorus obtained by plasma electrolytic oxidation of titanium. Materials 2020, 13, 828. [CrossRef] [PubMed]

70. Liang, T.; Wang, Y.; Zeng, L.; Liu, Y.; Qiao, L.; Zhang, S.; Zhao, R.; Li, G.; Zhang, R.; Xiang, J.; et al. Copper-doped 3D porous coating developed on Ti-6Al-4V alloys and its in vitro long-term antibacterial ability. Appl. Surf. Sci. 2020, 509. [CrossRef]

71. He, X.; Zhang, G.; Zhang, H.; Hang, R.; Huang, X.; Yao, X.; Zhang, X. Cu and Si co-doped microporous TiO2 coating for osseointegration by the coordinated stimulus action. Appl. Surf. Sci. 2020, 503. [CrossRef]

72. Zhang, L.; Guo, J.; Huang, X.; Zhang, Y.; Han, Y. The dual function of Cu-doped TiO2 coatings on titanium for application in percutaneous implants. J. Mater. Chem. B 2016, 4, 3788-3800. [CrossRef] [PubMed]

73. Huang, Q.; Li, X.; Elkhooly, T.A.; Liu, X.; Zhang, R.; Wu, H.; Feng, Q.; Liu, Y. The Cu-containing TiO2 coatings with modulatory effects on macrophage polarization and bactericidal capacity prepared by micro-arc oxidation on titanium substrates. Colloids Surf B Biointerfaces 2018, 170, 242-250. [CrossRef]

74. Yao, X.; Zhang, X.; Wu, H.; Tian, L.; Ma, Y.; Tang, B. Microstructure and antibacterial properties of Cu-doped TiO2 coating on titanium by micro-arc oxidation. Appl. Surf. Sci. 2014, 292, 944-947. [CrossRef]

75. Zhang, X.; Li, J.; Wang, X.; Wang, Y.; Hang, R.; Huang, X.; Tang, B.; Chu, P.K. Effects of copper nanoparticles in porous TiO2 coatings on bacterial resistance and cytocompatibility of osteoblasts and endothelial cells. Mater. Sci. Eng. C Mater. Biol. Appl. 2018, 82, 110-120. [CrossRef]

76. Zhao, D.; Lu, Y.; Zeng, X.; Wang, Z.; Liu, S.; Wang, T. Antifouling property of micro-arc oxidation coating incorporating Cu2O nanoparticles on Ti6Al4V. Surf. Eng. 2017, 33, 796-802. [CrossRef]

77. Zhang, L.; Guo, J.; Yan, T.; Han, Y. Fibroblast responses and antibacterial activity of Cu and Zn co-doped TiO2 for percutaneous implants. Appl. Surf. Sci. 2018, 434, 633-642. [CrossRef]

78. Zhao, D.; Lu, Y.; Wang, Z.; Zeng, X.; Liu, S.; Wang, T. Antifouling properties of micro arc oxidation coatings containing Cu2O/ZnO nanoparticles on Ti6Al4V. Int. J. Refract. Met. Hard Mater. 2016, 54, 417-421. [CrossRef]

79. Zhang, X.; Li, C.; Yu, Y.; Lu, X.; Lv, Y.; Jiang, D.; Peng, Z.; Zhou, J.; Zhang, X.; Sun, S.; et al. Characterization and property of bifunctional $\mathrm{Zn}$-incorporated $\mathrm{TiO} 2$ micro-arc oxidation coatings: The influence of different $\mathrm{Zn}$ sources. Ceram. Int. 2019, 45, 19747-19756. [CrossRef] 
80. Shimabukuro, M.; Tsutsumi, Y.; Nozaki, K.; Chen, P.; Yamada, R.; Ashida, M.; Doi, H.; Nagai, A.; Hanawa, T. Chemical and biological roles of Zinc in a porous titanium dioxide layer formed by micro-arc oxidation. Coatings 2019, 9, 705. [CrossRef]

81. Du, Q.; Wei, D.; Wang, Y.; Cheng, S.; Liu, S.; Zhou, Y.; Jia, D. The effect of applied voltages on the structure, apatite-inducing ability and antibacterial ability of micro arc oxidation coating formed on titanium surface. Bioact. Mater. 2018, 3, 426-433. [CrossRef] [PubMed]

82. Sopchenski, L.; Popat, K.; Soares, P. Bactericidal activity and cytotoxicity of a zinc doped PEO titanium coating. Thin Solid Film. 2018, 660, 477-483. [CrossRef]

83. Hu, H.; Zhang, W.; Qiao, Y.; Jiang, X.; Liu, X.; Ding, C. Antibacterial activity and increased bone marrow stem cell functions of Zn-incorporated TiO2 coatings on titanium. Acta Biomater. 2012, 8, 904-915. [CrossRef]

84. Zhang, X.; Wang, H.; Li, J.; He, X.; Hang, R.; Huang, X.; Tian, L.; Tang, B. Corrosion behavior of Zn-incorporated antibacterial TiO2 porous coating on titanium. Ceram. Int. 2016, 42, 17095-17100. [CrossRef]

85. Zhao, B.H.; Zhang, W.; Wang, D.N.; Feng, W.; Liu, Y.; Lin, Z.; Du, K.Q.; Deng, C.F. Effect of Zn content on cytoactivity and bacteriostasis of micro-arc oxidation coatings on pure titanium. Surf. Coat. Technol. 2013, 228, S428-S432. [CrossRef]

86. Leśniak-Ziółkowska, K.; Kazek-Kęsik, A.; Rokosz, K.; Raaen, S.; Stolarczyk, A.; Krok-Borkowicz, M.; Pamuła, E.; Gołda-Cępa, M.; Brzychczy-Włoch, M.; Simka, W. Electrochemical modification of the Ti-15Mo alloy surface in solutions containing ZnO and Zn3(PO4)2 particles. Mater. Sci. Eng. C 2020, 115. [CrossRef] [PubMed]

87. Zhang, L.; Gao, Q.; Han, Y. Zn and Ag Co-doped anti-microbial TiO2 coatings on Ti by micro-arc oxidation. J. Mater. Sci. Technol. 2016, 32, 919-924. [CrossRef]

88. Wang, Y.; Zhao, S.; Li, G.; Zhang, S.; Zhao, R.; Dong, A.; Zhang, R. Preparation and in vitro antibacterial properties of anodic coatings co-doped with $\mathrm{Cu}, \mathrm{Zn}$, and $\mathrm{P}$ on a Ti-6Al-4V alloy. Mater. Chem. Phys. 2020, 241. [CrossRef]

89. Matykina, E.; Arrabal, R.; Mingo, B.; Mohedano, M.; Pardo, A.; Merino, M.C. In vitro corrosion performance of PEO coated Ti and Ti6Al4V used for dental and orthopaedic implants. Surf. Coat. Technol. 2016, 307, 1255-1264. [CrossRef]

90. Wauthle, R.; Ahmadi, S.M.; Amin Yavari, S.; Mulier, M.; Zadpoor, A.A.; Weinans, H.; Van Humbeeck, J.; Kruth, J.P.; Schrooten, J. Revival of pure titanium for dynamically loaded porous implants using additive manufacturing. Mater. Sci. Eng. C Mater. Biol. Appl. 2015, 54, 94-100. [CrossRef]

91. Shah, F.A.; Thomsen, P.; Palmquist, A. Osseointegration and current interpretations of the bone-implant interface. Acta Biomater. 2019, 84, 1-15. [CrossRef]

92. Shah, F.A.; Trobos, M.; Thomsen, P.; Palmquist, A. Commercially pure titanium (cp-Ti) versus titanium alloy (Ti6Al4V) materials as bone anchored implants-Is one truly better than the other? Mater. Sci. Eng. C Mater. Biol. Appl. 2016, 62, 960-966. [CrossRef] [PubMed]

93. Elias, C.N.; Fernandes, D.J.; Souza, F.M.D.; Monteiro, E.d.S.; Biasi, R.S.D. Mechanical and clinical properties of titanium and titanium-based alloys (Ti G2, Ti G4 cold worked nanostructured and Ti G5) for biomedical applications. J. Mater. Res. Technol. 2019, 8, 1060-1069. [CrossRef]

94. Challa, V.S.; Mali, S.; Misra, R.D. Reduced toxicity and superior cellular response of preosteoblasts to Ti-6Al-7Nb alloy and comparison with Ti-6Al-4V. J. Biomed. Mater. Res. A 2013, 101, 2083-2089. [CrossRef]

95. Krząkała, A.; Kazek-Kęsik, A.; Simka, W. Application of plasma electrolytic oxidation to bioactive surface formation on titanium and its alloys. RSC Adv. 2013, 3. [CrossRef]

96. Rafieerad, A.R.; Ashra, M.R.; Mahmoodian, R.; Bushroa, A.R. Surface characterization and corrosion behavior of calcium phosphate-base composite layer on titanium and its alloys via plasma electrolytic oxidation: A review paper. Mater. Sci. Eng. C Mater. Biol. Appl. 2015, 57, 397-413. [CrossRef] [PubMed]

97. Lugovskoy, A.; Lugovskoy, S. Production of hydroxyapatite layers on the plasma electrolytically oxidized surface of titanium alloys. Mater. Sci. Eng. C Mater. Biol. Appl. 2014, 43, 527-532. [CrossRef] [PubMed]

98. Du, Q.; Wei, D.; Liu, S.; Cheng, S.; Hu, N.; Wang, Y.; Li, B.; Jia, D.; Zhou, Y. The hydrothermal treated Zn-incorporated titania based microarc oxidation coating: Surface characteristics, apatite-inducing ability and antibacterial ability. Surf. Coat. Technol. 2018, 352, 489-500. [CrossRef]

99. Lee, D.K.; Hwang, D.R.; Sohn, Y.-S. Surface properties of plasma electrolytic oxidation coatings on Ti-alloy in phosphate-based electrolytes with the addition of sodium metasilicate. Mol. Cryst. Liq. Cryst. 2019, 687, 7-13. [CrossRef]

100. Mohedano, M.; Guzman, R.; Arrabal, R.; Lopez Lacomba, J.L.; Matykina, E. Bioactive plasma electrolytic oxidation coatings-the role of the composition, microstructure, and electrochemical stability. J. Biomed. Mater. Res. B Appl. Biomater. 2013, 101, 1524-1537. [CrossRef]

101. Lu, X.; Mohedano, M.; Blawert, C.; Matykina, E.; Arrabal, R.; Kainer, K.U.; Zheludkevich, M.L. Plasma electrolytic oxidation coatings with particle additions-A review. Surf. Coat. Technol. 2016, 307, 1165-1182. [CrossRef]

102. Maitz, M.F.; Poon, R.W.; Liu, X.Y.; Pham, M.T.; Chu, P.K. Bioactivity of titanium following sodium plasma immersion ion implantation and deposition. Biomaterials 2005, 26, 5465-5473. [CrossRef]

103. Cai, K.; Lai, M.; Yang, W.; Hu, R.; Xin, R.; Liu, Q.; Sung, K.L. Surface engineering of titanium with potassium hydroxide and its effects on the growth behavior of mesenchymal stem cells. Acta Biomater. 2010, 6, 2314-2321. [CrossRef]

104. Zhang, X.; Yao, Z.; Jiang, Z.; Zhang, Y.; Liu, X. Investigation of the plasma electrolytic oxidation of Ti6Al4V under single-pulse power supply. Corros. Sci. 2011, 53, 2253-2262. [CrossRef] 
105. Shokouhfar, M.; Dehghanian, C.; Montazeri, M.; Baradaran, A. Preparation of ceramic coating on Ti substrate by plasma electrolytic oxidation in different electrolytes and evaluation of its corrosion resistance: Part II. Appl. Surf. Sci. 2012, 258, 2416-2423. [CrossRef]

106. Galvis, O.A.; Quintero, D.; Castaño, J.G.; Liu, H.; Thompson, G.E.; Skeldon, P.; Echeverría, F. Formation of grooved and porous coatings on titanium by plasma electrolytic oxidation in $\mathrm{H} 2 \mathrm{SO} 4 / \mathrm{H} 3 \mathrm{PO} 4$ electrolytes and effects of coating morphology on adhesive bonding. Surf. Coat. Technol. 2015, 269, 238-249. [CrossRef]

107. Durdu, S.; Bayramoğlu, S.; Demirtaş, A.; Usta, M.; Üçışık, A.H. Characterization of AZ31 Mg Alloy coated by plasma electrolytic oxidation. Vacuum 2013, 88, 130-133. [CrossRef]

108. Li, Z.; Yuan, Y.; Jing, X. Effect of current density on the structure, composition and corrosion resistance of plasma electrolytic oxidation coatings on Mg-Li alloy. J. Alloy. Compd. 2012, 541, 380-391. [CrossRef]

109. Montazeri, M.; Dehghanian, C.; Shokouhfar, M.; Baradaran, A. Investigation of the voltage and time effects on the formation of hydroxyapatite-containing titania prepared by plasma electrolytic oxidation on Ti-6Al-4V alloy and its corrosion behavior. Appl. Surf. Sci. 2011, 257, 7268-7275. [CrossRef]

110. Kossenko, A.; Lugovskoy, S.; Astashina, N.; Lugovskoy, A.; Zinigrad, M. Effect of time on the formation of hydroxyapatite in PEO process with hydrothermal treatment of the Ti-6Al-4V alloy. Glass Phys. Chem. 2013, 39, 639-642. [CrossRef]

111. Necula, B.S.; Apachitei, I.; Tichelaar, F.D.; Fratila-Apachitei, L.E.; Duszczyk, J. An electron microscopical study on the growth of TiO2-Ag antibacterial coatings on Ti6Al7Nb biomedical alloy. Acta Biomater 2011, 7, 2751-2757. [CrossRef]

112. Hasan, J.; Jain, S.; Padmarajan, R.; Purighalla, S.; Sambandamurthy, V.K.; Chatterjee, K. Multi-scale surface topography to minimize adherence and viability of nosocomial drug-resistant bacteria. Mater. Des. 2018, 140, 332-344. [CrossRef]

113. Zhang, Y.; Chen, S.E.; Shao, J.; Van den Beucken, J. Combinatorial surface roughness effects on osteoclastogenesis and osteogenesis. ACS Appl. Mater. Interfaces 2018, 10, 36652-36663. [CrossRef]

114. Sun, L.; Pereira, D.; Wang, Q.; Barata, D.B.; Truckenmuller, R.; Li, Z.; Xu, X.; Habibovic, P. Controlling growth and osteogenic differentiation of osteoblasts on microgrooved polystyrene surfaces. PLoS ONE 2016, 11, e0161466.

115. Yamada, M.; Ueno, T.; Tsukimura, N.; Ikeda, T.; Nakagawa, K.; Hori, N.; Suzuki, T.; Ogawa, T. Bone integration capability of nanopolymorphic crystalline hydroxyapatite coated on titanium implants. Int. J. Nanomed. 2012, 7, 859-873.

116. Lin, G.-W.; Chen, J.-S.; Tseng, W.; Lu, F.-H. Formation of anatase TiO2 coatings by plasma electrolytic oxidation for photocatalytic applications. Surf. Coat. Technol. 2019, 357, 28-35. [CrossRef]

117. Nosaka, Y.; Nosaka, A.Y. Generation and detection of reactive oxygen species in photocatalysis. Chem. Rev. 2017, 117, 11302-11336. [CrossRef]

118. Memar, M.Y.; Ghotaslou, R.; Samiei, M.; Adibkia, K. Antimicrobial use of reactive oxygen therapy: Current insights. Infect. Drug Resist. 2018, 11, 567-576. [CrossRef]

119. Li, K.; Xia, C.; Qiao, Y.; Liu, X. Dose-response relationships between copper and its biocompatibility/antibacterial activities. J. Trace Elem. Med. Biol. 2019, 55, 127-135. [CrossRef]

120. Pazos-Ortiz, E.; Roque-Ruiz, J.H.; Hinojos-Márquez, E.A.; López-Esparza, J.; Donohué-Cornejo, A.; Cuevas-González, J.C.; Espinosa-Cristóbal, L.F.; Reyes-López, S.Y. Dose-dependent antimicrobial activity of silver nanoparticles on polycaprolactone fibers against gram-positive and gram-negative bacteria. J. Nanomater. 2017, 2017, 4752314. [CrossRef]

121. Horky, P.; Skalickova, S.; Urbankova, L.; Baholet, D.; Kociova, S.; Bytesnikova, Z.; Kabourkova, E.; Lackova, Z.; Cernei, N.; Gagic, M.; et al. Zinc phosphate-based nanoparticles as a novel antibacterial agent: In vivo study on rats after dietary exposure. J. Anim. Sci. Biotechnol. 2019, 10, 17. [CrossRef]

122. Ferraris, S.; Spriano, S. Antibacterial titanium surfaces for medical implants. Mater. Sci. Eng. C Mater. Biol. Appl. 2016, 61, 965-978. [CrossRef]

123. Kedziora, A.; Speruda, M.; Krzyzewska, E.; Rybka, J.; Lukowiak, A.; Bugla-Ploskonska, G. Similarities and differences between silver ions and silver in nanoforms as antibacterial agents. Int. J. Mol. Sci. 2018, 19, 444. [CrossRef]

124. Stabryla, L.M.; Johnston, K.A.; Millstone, J.E.; Gilbertson, L.M. Emerging investigator series: It's not all about the ion: Support for particle-specific contributions to silver nanoparticle antimicrobial activity. Environ. Sci. Nano 2018, 5, 2047-2068. [CrossRef]

125. Riool, M.; De Boer, L.; Jaspers, V.; Van der Loos, C.M.; Van Wamel, W.J.B.; Wu, G.; Kwakman, P.H.S.; Zaat, S.A.J. Staphylococcus epidermidis originating from titanium implants infects surrounding tissue and immune cells. Acta Biomater. 2014, 10, 5202-5212. [CrossRef] [PubMed]

126. Jin, G.; Qin, H.; Cao, H.; Qian, S.; Zhao, Y.; Peng, X.; Zhang, X.; Liu, X.; Chu, P.K. Synergistic effects of dual Zn/Ag ion implantation in osteogenic activity and antibacterial ability of titanium. Biomaterials 2014, 35, 7699-7713. [CrossRef]

127. Jin, G.; Qin, H.; Cao, H.; Qiao, Y.; Zhao, Y.; Peng, X.; Zhang, X.; Liu, X.; Chu, P.K. Zn/Ag micro-galvanic couples formed on titanium and osseointegration effects in the presence of $S$. aureus. Biomaterials 2015, 65, 22-31. [CrossRef] [PubMed]

128. Kokubo, T.; Takadama, H. How useful is SBF in predicting in vivo bone bioactivity? Biomaterials 2006, 27, 2907-2915. [CrossRef]

129. Uhm, S.H.; Kwon, J.S.; Song, D.H.; Lee, E.J.; Jeong, W.S.; Oh, S.; Kim, K.N.; Choi, E.H.; Kim, K.M. Long-term antibacterial performance and bioactivity of plasma-engineered ag-nps/tio(2). J. Biomed. Nanotechnol. 2016, 12, 1890-1906. [CrossRef]

130. Otarigho, B.; Falade, B.O. Analysis of antibiotics resistant genes in different strains of Staphylococcus aureus. Bioinformation 2018, 14, 113-122. [CrossRef] [PubMed] 
131. Cremet, L.; Broquet, A.; Brulin, B.; Jacqueline, C.; Dauvergne, S.; Brion, R.; Asehnoune, K.; Corvec, S.; Heymann, D.; Caroff, N. Pathogenic potential of Escherichia coli clinical strains from orthopedic implant infections towards human osteoblastic cells. Pathog. Dis. 2015, 73, ftv065. [CrossRef]

132. Zimmerli, W.; Moser, C. Pathogenesis and treatment concepts of orthopaedic biofilm infections. FEMS Immunol. Med. Microbiol. 2012, 65, 158-168. [CrossRef]

133. McConoughey, S.J.; Howlin, R.; Granger, J.F.; Manring, M.M.; Calhoun, J.H.; Shirtliff, M.; Kathju, S.; Stoodley, P. Biofilms in periprosthetic orthopedic infections. Future Microbiol. 2014, 9, 987-1007. [CrossRef]

134. Barry, A.L.; National Committee for Clinical Laboratory Standards. Methods for Determining Bactericidal Activity of Antimicrobial Agents; Approved Guideline; CLSI: Wayne, PA, USA, 1999.

135. Jia, Z.; Xiu, P.; Li, M.; Xu, X.; Shi, Y.; Cheng, Y.; Wei, S.; Zheng, Y.; Xi, T.; Cai, H.; et al. Bioinspired anchoring AgNPs onto micro-nanoporous $\mathrm{TiO} 2$ orthopedic coatings: Trap-killing of bacteria, surface-regulated osteoblast functions and host responses. Biomaterials 2016, 75, 203-222. [CrossRef] [PubMed]

136. Applerot, G.; Lellouche, J.; Lipovsky, A.; Nitzan, Y.; Lubart, R.; Gedanken, A.; Banin, E. Understanding the antibacterial mechanism of $\mathrm{CuO}$ nanoparticles: Revealing the route of induced oxidative stress. Small 2012, 8, 3326-3337. [CrossRef]

137. Hans, M.; Erbe, A.; Mathews, S.; Chen, Y.; Solioz, M.; Mücklich, F. Role of copper oxides in contact killing of bacteria. Langmuir 2013, 29, 16160-16166. [CrossRef]

138. Afzal, M.A.F.; Kalmodia, S.; Kesarwani, P.; Basu, B.; Balani, K. Bactericidal effect of silver-reinforced carbon nanotube and hydroxyapatite composites. J. Biomater. Appl. 2012, 27, 967-978. [CrossRef]

139. Cao, H.; Qiao, Y.; Liu, X.; Lu, T.; Cui, T.; Meng, F.; Paul, C.K. Electron storage mediated dark antibacterial action of bound silver nanoparticles: Smaller is not always better. Acta Biomater. 2013, 9, 5100-5110. [CrossRef] [PubMed]

140. Torbert, J.T.; Joshi, M.; Moraff, A.; Matuszewski, P.E.; Holmes, A.; Pollak, A.N.; O’Toole, R.V. Current bacterial speciation and antibiotic resistance in deep infections after operative fixation of fractures. J. Orthop. Trauma 2015, 29, 7-17. [CrossRef] [PubMed]

141. Chen, A.F.; Schreiber, V.M.; Washington, W.; Rao, N.; Evans, A.R. What is the rate of methicillin-resistant Staphylococcus aureus and Gram-negative infections in open fractures? Clin. Orthop. Relat. Res. 2013, 471, 3135-3140. [CrossRef] [PubMed]

142. Tande, A.J.; Patel, R. Prosthetic joint infection. Clin. Microbiol. Rev. 2014, 27, 302-345. [CrossRef] [PubMed]

143. Corvec, S.; Portillo, M.E.; Pasticci, B.M.; Borens, O.; Trampuz, A. Epidemiology and new developments in the diagnosis of prosthetic joint infection. Int. J. Artif. Organs 2012, 35, 923-934. [CrossRef]

144. Campoccia, D.; Montanaro, L.; Arciola, C.R. The significance of infection related to orthopedic devices and issues of antibiotic resistance. Biomaterials 2006, 27, 2331-2339. [CrossRef]

145. Montanaro, L.; Speziale, P.; Campoccia, D.; Ravaioli, S.; Cangini, I.; Pietrocola, G.; Giannini, S.; Arciola, C.R. Scenery of Staphylococcus implant infections in orthopedics. Future Microbiol. 2011, 6, 1329-1349. [CrossRef]

146. Arciola, C.R.; Campoccia, D.; An, Y.H.; Baldassarri, L.; Pirini, V.; Donati, M.E.; Pegreffi, F.; Montanaro, L. Prevalence and antibiotic resistance of 15 minor staphylococcal species colonizing orthopedic implants. Int. J. Artif. Organs 2006, 29, 395-401. [CrossRef] [PubMed]

147. Moriarty, T.F.; Kuehl, R.; Coenye, T.; Metsemakers, W.J.; Morgenstern, M.; Schwarz, E.M.; Riool, M.; Zaat, S.A.J.; Khana, N.; Kates, S.L.; et al. Orthopaedic device-related infection: Current and future interventions for improved prevention and treatment. EFORT Open Rev. 2016, 1, 89-99. [CrossRef]

148. Del Pozo, J.L.; Patel, R. Infection associated with prosthetic joints. N. Engl. J. Med. 2009, 361, 787-794. [CrossRef]

149. Tan, T.L.; Kheir, M.M.; Shohat, N.; Tan, D.D.; Kheir, M.; Chen, C.; Parvizi, J. Culture-negative periprosthetic joint infection: An update on what to expect. J. Bone Jt. Surg. 2018, 3, e0060. [CrossRef] [PubMed]

150. Yoon, H.K.; Cho, S.H.; Lee, D.Y.; Kang, B.H.; Lee, S.H.; Moon, D.G.; Kim, D.H.; Nam, D.C.; Hwang, S.C. A review of the literature on culture-negative periprosthetic joint infection: Epidemiology. Diagn. Treat. Knee Surg. Relat. Res. 2017, 29, 155-164. [CrossRef]

151. Van Opijnen, T.; Dedrick, S.; Bento, J. Strain dependent genetic networks for antibiotic-sensitivity in a bacterial pathogen with a large pan-genome. PLoS Pathog. 2016, 12, e1005869. [CrossRef] [PubMed]

152. Losasso, C.; Belluco, S.; Cibin, V.; Zavagnin, P.; Micetic, I.; Gallocchio, F.; Zanella, M.; Bregoli, L.; Biancotto, G.; Ricci, A. Antibacterial activity of silver nanoparticles: Sensitivity of different Salmonella serovars. Front. Microbiol. 2014, 5, 227. [CrossRef] [PubMed]

153. Ruparelia, J.P.; Chatterjee, A.K.; Duttagupta, S.P.; Mukherji, S. Strain specificity in antimicrobial activity of silver and copper nanoparticles. Acta Biomater. 2008, 4, 707-716. [CrossRef] [PubMed]

154. Shivaram, A.; Bose, S.; Bandyopadhyay, A. Understanding long-term silver release from surface modified porous titanium implants. Acta Biomater. 2017, 58, 550-560. [CrossRef] [PubMed]

155. Zhai, Y.; Hunting, E.R.; Wouters, M.; Peijnenburg, W.J.; Vijver, M.G. Silver nanoparticles, ions, and shape governing soil microbial functional diversity: Nano shapes micro. Front. Microbiol. 2016, 7, 1123. [CrossRef]

156. Reidy, B.; Haase, A.; Luch, A.; Dawson, K.A.; Lynch, I. Mechanisms of silver nanoparticle release, transformation and toxicity: A critical review of current knowledge and recommendations for future studies and applications. Materials 2013, 6, 2295-2350. [CrossRef] [PubMed]

157. Balouiri, M.; Sadiki, M.; Ibnsouda, S.K. Methods for in vitro evaluating antimicrobial activity: A review. J. Pharm. Anal. 2016, 6, 71-79. [CrossRef] [PubMed] 
158. Hudson, M.C.; Ramp, W.K.; Frankenburg, K.P. Staphylococcus aureus adhesion to bone matrix and bone-associated biomaterials. FEMS Microbiol. Lett. 1999, 173, 279-284. [CrossRef] [PubMed]

159. Yang, D.; Wijenayaka, A.R.; Solomon, L.B.; Pederson, S.M.; Findlay, D.M.; Kidd, S.P.; Atkins, G.J. Novel insights into staphylococcus aureus deep bone infections: The involvement of osteocytes. mBio 2018, 9. [CrossRef]

160. Zimmerli, W.; Trampuz, A.; Ochsner, P.E. Prosthetic-joint infections. N. Engl. J. Med. 2004, 351, 1645-1654. [CrossRef]

161. Barrett, L.; Atkins, B. The clinical presentation of prosthetic joint infection. J. Antimicrob. Chemother. 2014, 69, i25-i27. [CrossRef]

162. Jorgensen, N.P.; Meyer, R.L.; Dagnaes-Hansen, F.; Fuursted, K.; Petersen, E. A modified chronic infection model for testing treatment of Staphylococcus aureus biofilms on implants. PLOS ONE 2014, 9, e103688.

163. Lebeaux, D.; Chauhan, A.; Rendueles, O.; Beloin, C. From in vitro to in vivo models of bacterial biofilm-related infections Pathogens 2013, 2, 288-356. [CrossRef] [PubMed]

164. Zimmerli, W.; Waldvogel, F.A.; Vaudaux, P.; Nydegger, U.E. Pathogenesis of foreign body infection: Description and characteristics of an animal model. J. Infect. Dis. 1982, 146, 487-497. [CrossRef] [PubMed]

165. Christo, S.N.; Diener, K.R.; Bachhuka, A.; Vasilev, K.; Hayball, J.D. Innate immunity and biomaterials at the nexus: Friends or foes. Biomed. Res. Int. 2015, 2015, 342304. [CrossRef] [PubMed]

166. Smith, A.W. Biofilms and antibiotic therapy: Is there a role for combating bacterial resistance by the use of novel drug delivery systems? Adv. Drug Deliv. Rev. 2005, 57, 1539-1550. [CrossRef]

167. Chan, K.H.; Zhuo, S.; Ni, M. Priming the surface of orthopedic implants for osteoblast attachment in bone tissue engineering. Int J. Med. Sci. 2015, 12, 701-707. [CrossRef] [PubMed]

168. Jayaraman, M.; Meyer, U.; Bühner, M.; Joos, U.; Wiesmann, H.-P. Influence of titanium surfaces on attachment of osteoblast-like cells in vitro. Biomaterials 2004, 25, 625-631. [CrossRef]

169. Yao, J.J.; Lewallen, E.A.; Trousdale, W.H.; Xu, W.; Thaler, R.; Salib, C.G.; Reina, N.; Abdel, M.P.; Lewallen, D.G.; Van Wijnen, A.J. Local cellular responses to titanium dioxide from orthopedic implants. Biores Open Access 2017, 6, 94-103. [CrossRef]

170. Stewart, C.; Akhavan, B.; Wise, S.G.; Bilek, M.M.M. A review of biomimetic surface functionalization for bone-integrating orthopedic implants: Mechanisms, current approaches, and future directions. Prog. Mater. Sci. 2019, 106. [CrossRef]

171. Shekaran, A.; Garcia, A.J. Extracellular matrix-mimetic adhesive biomaterials for bone repair. J. Biomed. Mater. Res. A 2011, 96, 261-272. [CrossRef]

172. Long, E.G.; Buluk, M.; Gallagher, M.B.; Schneider, J.M.; Brown, J.L. Human mesenchymal stem cell morphology, migration, and differentiation on micro and nano-textured titanium. Bioact. Mater. 2019, 4, 249-255. [CrossRef]

173. Jiang, H.; Hong, T.; Wang, T.; Wang, X.; Cao, L.; Xu, X.; Zheng, M. Gene expression profiling of human bone marrow mesenchymal stem cells during osteogenic differentiation. J. Cell. Physiol. 2019, 234, 7070-7077. [CrossRef] [PubMed]

174. Klontzas, M.E.; Vernardis, S.I.; Heliotis, M.; Tsiridis, E.; Mantalaris, A. Metabolomics analysis of the osteogenic differentiation of umbilical cord blood mesenchymal stem cells reveals differential sensitivity to osteogenic agents. Stem Cells Dev. 2017, 26, 723-733. [CrossRef] [PubMed]

175. Bennett, K.P.; Bergeron, C.; Acar, E.; Klees, R.F.; Vandenberg, S.L.; Yener, B.; Plopper, G.E. Proteomics reveals multiple routes to the osteogenic phenotype in mesenchymal stem cells. BMC Genom. 2007, 8, 380. [CrossRef] [PubMed]

176. Hosseini, F.S.; Soleimanifar, F.; Ardeshirylajimi, A.; Vakilian, S.; Mossahebi-Mohammadi, M.; Enderami, S.E.; Khojasteh, A.; Zare Karizi, S. In vitro osteogenic differentiation of stem cells with different sources on composite scaffold containing natural bioceramic and polycaprolactone. Artif. Cells Nanomed. Biotechnol. 2019, 47, 300-307. [CrossRef]

177. Pineiro-Ramil, M.; Sanjurjo-Rodriguez, C.; Castro-Vinuelas, R.; Rodriguez-Fernandez, S.; Fuentes-Boquete, I.M.; Blanco, F.J.; Diaz-Prado, S.M. Usefulness of Mesenchymal cell lines for bone and cartilage regeneration research. Int. J. Mol. Sci. 2019, 20, 6286. [CrossRef]

178. Florencio-Silva, R.; Sasso, G.R.; Sasso-Cerri, E.; Simoes, M.J.; Cerri, P.S. Biology of bone tissue: Structure, function, and factors that influence bone cells. Biomed. Res. Int. 2015, 2015, 421746. [CrossRef]

179. Qin, Y.; Guan, J.; Zhang, C. Mesenchymal stem cells: Mechanisms and role in bone regeneration. Postgrad. Med. J. 2014, 90, 643-647. [CrossRef]

180. Chiba, H.; Sawada, N.; Ono, T.; Ishii, S.; Mori, M. Establishment and characterization of Simian virus-40 immortalized osteoblastic cell line from normal human bone. Jpn. J. Cancer Res. 1993, 84, 290-297. [CrossRef] [PubMed]

181. Wagner, E.R.; Luther, G.; Zhu, G.; Luo, Q.; Shi, Q.; Kim, S.H.; Gao, J.L.; Huang, E.; Gao, Y.; Yang, K.; et al. Defective osteogenic differentiation in the development of osteosarcoma. Sarcoma 2011, 2011, 325238. [CrossRef]

182. Hankenson, K.D.; Dishowitz, M.; Gray, C.; Schenker, M. Angiogenesis in bone regeneration. Injury 2011, 42, 556-561. [CrossRef] [PubMed]

183. Razzi, F.; Fratila-Apachitei, L.E.; Fahy, N.; Bastiaansen-Jenniskens, Y.M.; Apachitei, I.; Farrell, E.; Zadpoor, A.A. Immunomodulation of surface biofunctionalized 3D printed porous titanium implants. Biomed. Mater. 2020, 15, 035017. [CrossRef] [PubMed]

184. Pirraco, R.P.; Cerqueira, M.T.; Reis, R.L.; Marques, A.P. Fibroblasts regulate osteoblasts through gap junctional communication. Cytotherapy 2012, 14, 1276-1287. [CrossRef] [PubMed]

185. Pennings, I.; Van Dijk, L.A.; Van Huuksloot, J.; Fledderus, J.O.; Schepers, K.; Braat, A.K.; Hsiao, E.C.; Barruet, E.; Morales, B.M.; Verhaar, M.C.; et al. Effect of donor variation on osteogenesis and vasculogenesis in hydrogel cocultures. J. Tissue Eng. Regen. Med. 2019, 13, 433-445. [CrossRef] [PubMed] 
186. Zhao, L.; Li, G.; Chan, K.M.; Wang, Y.; Tang, P.F. Comparison of multipotent differentiation potentials of murine primary bone marrow stromal cells and mesenchymal stem cell line C3H10T1/2. Calcif. Tissue Int. 2009, 84, 56-64. [CrossRef] [PubMed]

187. Scuteri, A.; Donzelli, E.; Foudah, D.; Caldara, C.; Redondo, J.; D’Amico, G.; Tredici, G.; Miloso, M. Mesengenic differentiation: Comparison of human and rat bone marrow mesenchymal stem cells. Int. J. Stem Cells 2014, 7, 127-134. [CrossRef] [PubMed]

188. Levi, B.; Nelson, E.R.; Brown, K.; James, A.W.; Xu, D.; Dunlevie, R.; Wu, J.C.; Lee, M.; Wu, B.; Commons, G.W.; et al. Longaker, Differences in osteogenic differentiation of adipose-derived stromal cells from murine, canine, and human sources in vitro and in vivo. Plast. Reconstr. Surg. 2011, 128, 373-386. [CrossRef]

189. Zhao, L.; Wang, H.; Huo, K.; Cui, L.; Zhang, W.; Ni, H.; Zhang, Y.; Wu, Z.; Chu, P.K. Antibacterial nano-structured titania coating incorporated with silver nanoparticles. Biomaterials 2011, 32, 5706-5716. [CrossRef]

190. Drago, L.; De Vecchi, E.; Bortolin, M.; Zagra, L.; Romano, C.L.; Cappelletti, L. Epidemiology and antibiotic resistance of late prosthetic knee and hip infections. J. Arthroplast. 2017, 32, 2496-2500. [CrossRef]

191. Panacek, A.; Kvitek, L.; Smekalova, M.; Vecerova, R.; Kolar, M.; Roderova, M.; Dycka, F.; Sebela, M.; Prucek, R.; Tomanec, O.; et al. Bacterial resistance to silver nanoparticles and how to overcome it. Nat. Nanotechnol. 2018, 13, 65-71. [CrossRef]

192. Richard, D.; Ravigne, V.; Rieux, A.; Facon, B.; Boyer, C.; Boyer, K.; Grygiel, P.; Javegny, S.; Terville, M.; Canteros, B.I.; et al. Adaptation of genetically monomorphic bacteria: Evolution of copper resistance through multiple horizontal gene transfers of complex and versatile mobile genetic elements. Mol. Ecol. 2017, 26, 2131-2149. [CrossRef]

193. Cavaco, L.M.; Hasman, H.; Aarestrup, F.M. Zinc resistance of Staphylococcus aureus of animal origin is strongly associated with methicillin resistance. Vet. Microbiol. 2011, 150, 344-348. [CrossRef]

194. Percival, S.L.; Bowler, P.G.; Russell, D. Bacterial resistance to silver in wound care. J. Hosp. Infect. 2005, 60, 1-7. [CrossRef] [PubMed]

195. Saran, U.; Gemini Piperni, S.; Chatterjee, S. Role of angiogenesis in bone repair. Arch. Biochem. Biophys. 2014, 561, 109-117. [CrossRef]

196. Lee, J.; Byun, H.; Madhurakkat Perikamana, S.K.; Lee, S.; Shin, H. Current advances in immunomodulatory biomaterials for bone regeneration. Adv. Healthc. Mater. 2019, 8, e1801106. [CrossRef] [PubMed]

197. Geraghty, R.J.; Capes-Davis, A.; Davis, J.M.; Downward, J.; Freshney, R.I.; Knezevic, I.; Lovell-Badge, R.; Masters, J.R.; Meredith, J.; Stacey, G.N.; et al. Guidelines for the use of cell lines in biomedical research. Br. J. Cancer 2014, 111, 1021-1046. [CrossRef] [PubMed]

198. Bankier, C.; Matharu, R.K.; Cheong, Y.K.; Ren, G.G.; Cloutman-Green, E.; Ciric, L. Synergistic antibacterial effects of metallic nanoparticle combinations. Sci. Rep. 2019, 9, 16074. [CrossRef] [PubMed]

199. Worthington, R.J.; Melander, C. Combination approaches to combat multidrug-resistant bacteria. Trends Biotechnol. 2013, 31, 177-184. [CrossRef]

200. Sobolev, A.; Valkov, A.; Kossenko, A.; Wolicki, I.; Zinigrad, M.; Borodianskiy, K. Bioactive coating on Ti alloy with high osseointegration and antibacterial Ag nanoparticles. ACS Appl. Mater. Interfaces 2019, 11, 39534-39544. [CrossRef]

201. Durdu, S. Characterization, bioactivity and antibacterial properties of copper-based TiO2 bioceramic coatings fabricated on Titanium. Coatings 2018, 9, 1. [CrossRef]

202. Fazel, M.; Salimijazi, H.R.; Shamanian, M.; Apachitei, I.; Zadpoor, A.A. Influence of hydrothermal treatment on the surface characteristics and electrochemical behavior of Ti-6Al-4V bio-functionalized through plasma electrolytic oxidation. Surf. Coat. Technol. 2019, 374, 222-231. [CrossRef]

203. Park, T.-E.; Choe, H.-C.; Brantley, W.A. Bioactivity evaluation of porous TiO2 surface formed on titanium in mixed electrolyte by spark anodization. Surf. Coat. Technol. 2013, 235, 706-713. [CrossRef]

204. He, J.; Feng, W.; Zhao, B.H.; Zhang, W.; Lin, Z. In vivo effect of Titanium implants with porous Zinc-containing coatings prepared by plasma electrolytic oxidation method on osseointegration in rabbits. Int. J. Oral Maxillofac. Implant. 2018, 33, 298-310. [CrossRef] [PubMed]

205. Croes, M.; De Visser, H.; Meij, B.P.; Lietart, K.; Van der Wal, B.C.H.; Vogely, H.C.; Fluit, A.C.; Boel, C.H.E.; Alblas, J.; Weinans, H.; et al. Data on a rat infection model to assess porous titanium implant coatings. Data Brief. 2018, 21, 1642-1648. [CrossRef] [PubMed] 